UNIVERSITY OF SÃO PAULO

SCHOOL OF PHILOSOPHY, LITERATURE AND HUMAN SCIENCES

DEPARTMENT OF PHILOSOPHY

PhD PROGRAMME

Adriana Toledo Piza

\title{
The Buddhist Concept of Selflessness According to Je Tsongkhapa
}

Revised Version 
Adriana Toledo Piza

\title{
The Buddhist Concept of Selflessness According to Je Tsongkhapa
}

\author{
Revised Version
}

This thesis is presented at the $\mathrm{PhD}$ program on Philosophy of the School of Philosophy,

Literature and Human Sciences of the University of São Paulo for obtaining the degree of Doctor of Philosophy under the supervision of Prof. PhD João Vergílio Gallerani Cuter 
Autorizo a reprodução e divulgação total ou parcial deste trabalho, por qualquer meio convencional ou eletrônico, para fins de estudo e pesquisa, desde que citada a fonte.

Catalogação na Publicação

Serviço de Biblioteca e Documentação

Faculdade de Filosofia, Letras e Ciências Humanas da Universidade de São Paulo

P $695 t$

Piza, Adriana Toledo

The Buddhist Concept of Selflessness According to

Je Tsongkhapa / Adriana Toledo Piza ; orientador

João Vergílio Gallerani Cuter. - São Paulo, 2019.

$180 \mathrm{f}$.

Tese (Doutorado) - Faculdade de Filosofia, Letras e Ciências Humanas da Universidade de São Paulo. Departamento de Filosofia. Área de concentração: Filosofia.

1. Filosofia. I. Cuter, João Vergílio Gallerani, orient. II. Título. 


\section{ENTREGA DO EXEMPLAR CORRIGIDO DA DISSERTAÇÃO/TESE \\ Termo de Ciência e Concordância do (a) orientador (a)}

Nome do (a) aluno (a): Adriana Toledo Piza

Data da defesa: 22 / $02 / 2019$

Nome do Prof. (a) orientador (a): Prof. Dr. João Vergílio Gallerani Cuter

Nos termos da legislação vigente, declaro ESTAR CIENTE do conteúdo deste EXEMPLAR CORRIGIDO elaborado em atenção às sugestões dos membros da comissão Julgadora na sessão de defesa do trabalho, manifestando-me plenamente favorável ao seu encaminhamento e publicação no Portal Digital de Teses da USP.

São Paulo, 20 / 04 / 2019






\section{Acknowledgements}

I would like to express my sincere appreciation, first of all, to my doctoral advisor, Prof. PhD João Vergílio Gallerani Cutter, for his earnest inspiriting and constructive critiques, as well as for his constant support in all possible manners to my endeavors throughout the whole doctorate program. I also wish to express my very deep gratitude to Ven. Gonsar Tulku Rinpoche, Director and principal Professor at the Center for Higher Tibetan Studies Rabten Choeling, in Switzerland, for having guided me through the complexity of Gelug Buddhist philosophy, as well as for his valuable advice and assistance to my efforts for carrying out an academical research on this subject. Special thanks must also go to Ven. Lama Gangchen Tulku Rinpoche, not only for having first introduced me to the writings of Je Tsongkhapa, but also for the unconditional offer of support and encouragement to my engagement towards the deepening of my studies.

I am particularly grateful to Marina Simen and Peter Caccivio for their precious financial support, which enabled me to attend lectures and courses both at the Goethe University Frankfurt, in Germany, and at the Center for Higher Tibetan Studies Rabten Choeling, in Switzerland, during the years 2016, 2017 and 2018.

I must also thank Prof. PhD Wilhelm Essler, from the Department of Philosophy of the Goethe University Frankfurt, in Germany, for his very productive assistance, and Rosângela Amato, for her precious help in the final revision. And lastly, I express my gratitude to many others who have contributed in different ways for the accomplishment of this project. They are: Fernanda Toledo Piza, Gisele Barroco, Changchub Trinley, Sueli Arcocha, Leo Lang, Ramona Pou Bruch, Francesco Prevosti, Rosie Mehoudar, Monica Guimarães, Geisa dos Santos, Nicole Arndt, Eden Lamdark, Catherine Pleteshner, Hsia Cheng Pei and Ulas Gergin.

In conclusion, thanks must be given to CAPES, for the funding of four years of full dedication to the $\mathrm{PhD}$ program. 


\section{Abstract}

This doctoral research has the purpose of articulating a consistent presentation of the Buddhist concept of selflessness as explained by the great Tibetan Buddhist scholar Tsongkhapa (Tibet, 1357-1419 CE), who composed some major philosophical masterpieces about this key Buddhist concept based on Nāgārjuna's (India, ca 150-250 CE) famous Mūla-madhyamaka-kārikā (MMK). Tsongkhapa presents himself as a follower of Nāgārjuna, that is, as a proponent of the 'Middle Way' (madhyamaka, dbu ma pa) Buddhist philosophical school. As our study of the first treatise in which he presents his view on selflessness advanced, we realized that it was necessary to dedicate part of our research to the analysis of the epistemological theory that substantiates his explanation of selflessness, since his approach to the subject is based on the use of what he calls 'rational analysis' and 'inferential knowledge'. Therefore, a preliminary part of our thesis is dedicated to the clarification of Tsongkhapa's conceptions of rational analysis and inferential knowledge, which are based primarily on the theory of 'valid cognition' (pramāna, tshad ma) elaborated centuries earlier by the great Indian scholar Dharmakīrti $\left(6^{\text {th }}\right.$ and $7^{\text {th }}$ centuries CE). The next stage of our research was guided by the following question: since, for Tsongkhapa, not possessing a self means the same as not possessing a nature (svabhāva, rang zhin), a concept upon which Dharmakīrti's explanation of inferential knowledge is based, how does Tsongkhapa combine his presentation of selflessness with Dharmakīrti's epistemology without generating internal contradictions in his system? We have concluded that, in Tsongkhapa's presentation of selflessness as united with causation, that is, as one implying the other due to the introduction of the key distinction between 'inherent nature' and 'mere nature', there is no contradiction between his epistemological use of inferences based on the notion of mere natures (recognized as conventional) and his final ontological assertion that phenomena lack inherent natures.

Key-words: Buddhist Philosophy, Madhyamaka, inference, dependent-origination, selflessness. 


\section{O Conceito Budista de 'Anatma' (Ausência de Identidade) Segundo Je Tsongkhapa}

\section{Resumo}

A presente pesquisa de doutoramento tem por finalidade articular uma apresentação consistente do conceito budista de anatma (ausência de identidade) segundo a explicação do grande pensador tibetano Tsongkhapa (Tibete, 1357-1419 D.C.), que compôs relevantes obras filosóficas sobre esse conceito budista fundamental, baseadas no famoso tratado Mūla-madhyamaka-kārikā (MMK) de Nāgārjuna (Índia, ca 150-250 D.C.). Tsongkhapa se apresenta como um seguidor de Nāgārjuna, ou seja, como um proponente da escola de filosofia budista 'Caminho do Meio' (madhyamaka, dbu ma pa). À medida que nosso estudo do primeiro tratado em que ele articula sua visão da noção de anatma (ausência de identidade) se desenvolvia, percebemos que seria necessário dedicar parte de nossa pesquisa à análise da teoria epistemológica que fundamenta sua explicação da 'ausência de identidade' (dos fenômenos), visto que sua abordagem baseia-se na utilização do que ele chama de 'análise racional' e 'conhecimento por inferência'. Dessa forma, a primeira parte de nossa tese é dedicada à compreensão das noções de 'análise racional' e 'conhecimento por inferência' usadas por Tsongkhapa, que se baseiam principalmente na teoria sobre as 'cognições válidas' (pramāna, tshad $m a$ ), elaborada séculos antes pelo grande pensador indiano Dharmakīrti (séculos VI e VII). A etapa seguinte de nosso trabalho teve como fio-condutor a seguinte questão: visto que, para Tsongkhapa, a ausência de identidade (anatma, dak me) significa o mesmo que não ser dotado de uma 'natureza' (svabhāva, rang zhin), conceito sobre o qual a explicação de Dharmakīrti do conhecimento por inferência se baseia, como Tsongkhapa elabora conceitualmente a articulação da epistemologia de Dharmakīrti com sua explicação da ausência de identidade dos fenômenos sem gerar contradições internas em seu sistema? Concluímos que, na apresentação de Tsongkhapa, em que a noção de causalidade passa a implicar a de 'ausência de identidade' devido à introdução da distinção essencial entre 'natureza inerente' e 'mera natureza', não há contradição entre seu uso epistemológico de inferências baseadas na noção de 'meras naturezas' (reconhecidas como convencionais) e sua afirmação ontológica final da ausência de natureza inerente nos fenômenos.

Palavras-chave: filosofia budista, Madhyamaka, inferência, origem-dependente, ausência de identidade. 


\section{Technical Note}

Transliterated Sanskrit words mentioned throughout this work were not transliterated by us. They were taken from the translations by John D. Dunne and Th. Stcherbatsky, from the TibetanEnglish Dictionary of Buddhist Terminology by Tsepak Rigzin (which provides the original Sanskrit terms of their Tibetan correspondent translations) and from the The Stanford Encyclopedia of Philosophy online.

Transliterated Tibetan words were transliterated by us, using the Extended Wylie Transliteration Scheme (www.thlib.org/reference/transliteration/\#! essay=/thl/ewts). 


\section{Table of Contents}

\section{Part One:}

\section{Introduction}

Chapter I - General Introduction to this Work 10

Chapter II - General Historical Introduction to Buddhist Philosophy

\section{Part Two:}

Je Tsongkhapa's Philosophical Background

Chapter I - Introduction

Chapter II - General Buddhist Ontology According to Gelug Manuals 41

Chapter III - Dharmakīrti's Ontology 44

Chapter IV - Dharmakīrti's Epistemology 54

Chapter V - Dharmakīrti's Epistemology According to Gelug Manuals 63

\section{Part Three:}

The Buddhist View of Selflessness According to Je Tsongkhapa

Chapter I - Introduction

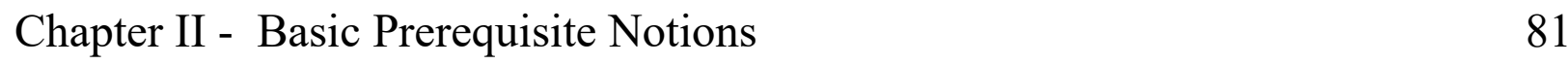

Chapter III - Why it is Necessary to Practice Vipaśyana 88 
Chapter IV - How to Establish the View of Emptiness 96

Chapter V - Misconceptions of the Object of Negation 105

Chapter VI - Applying the Rational Analysis to Negate Inherent Nature 138

$\begin{array}{ll}\text { Conclusion } & 160\end{array}$

$\begin{array}{ll}\text { References } & 175\end{array}$ 


\section{Part One}

\section{Introduction}




\section{Chapter I}

\section{General Introduction to this Work}

The main theme of this work, as clearly expressed in its title, is the Buddhist concept of 'selflessness' according to the Buddhist master Je Tsongkhapa. In our first approach to Tsongkhapa 's work The Great Exposition of the Stages of the Path (Byang chub lam rim che pa), PartTwo; Insight, which is the text analyzed in this thesis, our attention was drawn by three subject matters that determined the further orientation of our research. They are:

1) The philosophical challenge

The main issue that moves Tsongkhapa's arguments and reflections is the challenge of uniting two ontological assertions which, in other philosophical systematizations - both Buddhist as well as non-Buddhists -, appear generally as contradictory with each other. The first one is the assertion of the truth of the causal production of phenomena, and the second one is the assertion that phenomena do not possess a nature in themselves, since such a nature is actually constituted in the cognitive event.

Why do those two statements seem contradictory with each other? According to 
Tsongkhapa, the seeming contradiction between them is due to the fact that the first proposition the truth of the causal production of phenomena - apparently, and only apparently, necessarily brings with it another implicit ontological assertion: the conception that phenomena which are existentially connected by cause-effect relations must be endowed with their 'specific natures', or 'specific essences'. For most philosophical systems, this seems to be the only possible way to explain the regular production of distinct phenomena - that is - the fact that an apple seed produces always an apple tree, and never a lemon tree, wind nor fish. In other words, an apple seed must be conceived as possessing its own specific nature, or essence, of apple seed, in the sense that it possesses its own specific 'complex of causal potentialities', which is what truly responds for the fact that this phenomenon - apple seed - always necessarily produces its own specific effect: an apple tree. The same idea is also valid in relation to the sphere of human actions, behavior and activities, that is, specific actions are endowed with specific characteristics which alone explain the outcome of their specific results.

The difficulty of uniting the two aforementioned ontological assertions can be expressed in simpler terms in the following way: how can we affirm that phenomena are created by the cognitive event and, at the same time, that causality is real? For Tsongkhapa, the combination of those two affirmations in one sole conception, that is, in one sole view of reality, must be done in an absolutely consistent way. This means that it must leave no breaches whatsoever for any type of contradictions nor fissures. The word 'fissure' here refers to the possibility of, for example, unfolding this sole view of reality in two different levels for two different types of beings, like the conception according to which the truth of the causality of phenomena pertains only to the deluded conceptions of ordinary beings whereas the fully awakened ones (the Buddhas), in their direct absorption into emptiness, do not perceive causal production as real. Different from that, in Tsongkhapa's view, finding the convergence between causality and emptiness is the true task of those seeking to establish in their minds the correct view of reality, and specially, it is the true task of those who call themselves 'Mādhyamikas', that is, followers of the so-called Buddhist MiddleWay School, since the very junction of causality and emptiness is the only possibly conceivable Middle Way taught by the Buddha. 
2) The notion of 'rational analysis'

The second aspect of Tsongkhapa's text that caught our attention during the first reading was the capital notion of 'rational analysis'. The central role played by the use of the 'rational analysis' in Tsongkhapa's method for finding the Middle Way raised the following question: what exactly is his concept of 'reasoning', and what kind of epistemology substantiates the validity of utilizing 'reasoning' in the path towards the direct perception of the ultimate level of phenomena, the one called 'reality', 'thatness' or 'emptiness'?

3) The concept of 'valid cognition'

The third aspect that seemed fundamental was the concept of 'valid cognition', which displays a central role in Tsongkhapa's argumentation. According to him, the conception of the mere existence, or mere establishment, of phenomena, as opposed to their inherent existence, or existence in themselves and by themselves, is based on the 'valid cognition' of those phenomena alone, and this base suffices to guarantee the truth of their functionality, there being no necessity whatsoever of resorting to the conception of phenomena as inherently possessing their natures in order to sustain their effectiveness in the causal production.

The crucial importance of the notions of 'reasoning' and 'valid cognition' in Tsongkhapa's text determined the direction of the first part of our research, which took as its focal point of investigation the field of the epistemological conceptions adopted by Tsongkhapa, which, although not explicitly articulated in his exposition of emptiness, serve as a solid ground for the central lines of arguments in his reflection.

The first part of our thesis, therefore, addresses the comprehension of the theory of cognition that sustains Tsongkhapa's presentation of emptiness. As it proved impossible for us to have access to Tsongkhapa's work that explains the epistemology adopted by him ${ }^{1}$, we used as our source of 1 A Door of Entry to the Seven Treatises ( $s D$ bdun la 'jug pa'i sgo), Tsongkhapa's personal explanation of Dharmakīrti 's epistemology (KLEIN; 1991, p.24). 
information the Gelug traditional manuals - all based on Tsongkhapa's text - which have been already translated into English. The study of the manuals allowed us to identify the essential distinction which seems to sustain Tsongkhapa's line of reflection in the treatise, namely, the distinction between, on one hand, the direct perception of sense data - named as 'complete engager' - and on the other hand, the domain of the cognitions mediated by the categories of language and thought - called 'partial engagers'. The 'partial engagers', that is, the cognitions which are already mediated by the categories of language and thought, like 'this is a table' or 'that is a tree', are characterized as processes of knowledge that work by means of separating, or isolating, as they call it in Tibetan, specific aspects of the sense data. Those isolated aspects of the perception of phenomena are the bases upon which the ordinary categories of language and thought are construed.

The use of such epistemological concepts allows Tsongkhapa to sustain a view that affirms the existence of a continuity between the domain of daily language and thought, with its pragmatical activities, on one side, and the sphere of philosophical investigation, or rather, of 'philosophical-meditative' search, for the subtlest and most fundamental mode of existence, or mode of establishment, of phenomena. In other words, the naive daily pragmatic language and reasoning - in which the categories that allow us to understand, up to a certain degree, the causal production of phenomena are construed as functional conventions - appears united in one same ontological continuity with the most fundamental sphere encountered by the Buddhist meditation as the dependent origination of phenomena together with phenomena's emptiness of inherent existence. Language and thought are grounded thus on this subtlest level of phenomena called 'reality', or 'thatness', although they certainly present a high degree of incompleteness, and even distortion, in the manner in which they represent the functionality - or continuous moving forward - of the dependent origination of phenomena.

Given the affirmation of this ontological continuity between the level of language/thought and the subtlest level of reality, the task that lies ahead of Tsongkhapa in the treatise where he presents his conception of emptiness is the establishment of arguments to defend the idea that the emptiness of inherent nature of phenomena is not contradictory with the affirmation of the truth of the causal production of phenomena. Tsongkhapa articulates this 'non-contradiction' utilizing the notion of 'correct (and precise) object of negation'. What is called 'negation' here refers to emptiness. Emptiness is understood as 'empty of', in the sense of 'absence of something misconceived' which is erroneously apprehended, or rather 'fabricated', in the cognition event.

Tsongkhapa endeavors to demonstrate that the factor that leads to the view that opposes the 
truth of causal production to the emptiness of inherent nature is exactly this lack of a correct and precise determination of the misconceived element which is fabricated erroneously in the cognitive event. This lack of a precise determination of the object to be negated unfolds into two types of misconceptions: negating more than what is supposed to be negated and negating less than what should be negated.

Negating more than what is supposed to be negated involves, basically, negating not only the misconception of a certain mode of existence, or establishment, of the object of cognition, but actually negating the very existence, or establishment, of the object of cognition. Here Tsongkhapa has as his target conceptions of emptiness which, according to him, were frequently propagated by contemporary Tibetan Buddhist masters. Negating less than what should be negated, on the other hand, involves negating only the superficial layers of the object to be negated (the self), leaving untouched its most fundamental core, its root, which is said to be very subtle and difficult to grasp in the process of philosophical meditation. As an antidote to these erroneous views, Tsongkhapa propounds a return to the writings of the great Indian Buddhist masters, especially Nāgārjuna and Candrakīrti, both richly quoted in his argumentation.

One important aspect of Tsongkhapa's treatise which we consider necessary to observe here in order to prepare the reader who is familiar only with philosophical writings pertaining to the European tradition of thought is the fact that Tsongkhapa's text does not approach the challenge of uniting the two aforementioned ontological assertions - the truth of causal production and the emptiness of inherent existence - as a philosophical challenge in the same sense as the word 'philosophy' may disclose for the tradition of European thought. For Tsongkhapa, it is a different type of challenge, a challenge that we could perhaps classify as a 'meditative-philosophical' challenge. 'Philosophical', yes, not only because it uses rational types of analysis which are very close to the methodologies found in the European philosophical tradition, but also because it deals with subject matters of reflection and inquiry which are abundantly present in the masterpieces of European thought.

Nevertheless, it is necessary to point out an essential difference that Tsongkhapa's work presents to us. He says in the treatise: “... philosophical determinations are made for the purpose of meditation." (TSONGKHAPA, 2002, p. 279) Indeed, his text is actually a description, or rather, a transmission of a set of instructions for a meditative exercise which utilizes very specific and highly precise techniques with the purpose of generating a particular 'philosophical view' (or 'view of reality'), namely, the union between dependent-origination of phenomena and their emptiness of 
inherent existence, in the mental continuum of a meditator. Supposedly, the view thus generated does correspond to reality, a fact which should be confirmed in further stages of this meditative exercise, which must evolve and refine itself to the point of being actually transformed into a direct perception - that means, a non-conceptual perception - of reality as indeed revealing those two aspects - or two truths.

Therefore, since Tsongkhapa's text is actually a transmission of instructions for a meditative practice, he naturally treats the ideas that oppose the view which he is propounding as 'mental positions' to be overcome by the correct use of specific analytical exercises. He explains to us how, in the course of the first stages of the vipaśyana (lhag mthong) meditation, those mistaken mental positions alternate in the practitioner's mind. When one attains a deeper understanding of the fact that phenomena originate as a result of the gathering of specific causes and conditions, one has no possibility of seeing those phenomena that originate within the cause-effect relationship as being at the same time empty of their own [inherent] natures, or as being selfless, empty of their own [inherent] identity. On the contrary, phenomena appear as if they MUST have their natures inherently so as to guarantee the efficiency of the causal relation. This is the view of causality that we have ordinarily. On the other hand, when one generates some view of the emptiness of [inherent] nature through the use of the rational analysis, realizing thus that the identity, or self, of phenomena is construed by the cognitive event, one then is not able to see phenomena as existing nor as functioning in the cause-effect relations. One sees the emptiness as if phenomena simply did not exist nor could fulfill truly their real functioning.

As the vipaśyanā (lhag mthong) meditation develops, this opposition is gradually surmounted until eventually the two views get combined in one sole conception, like two sides of the same leaf. When those two understandings - the dependent origination of phenomena and their emptiness of [inherent] nature - cease to take place separately in one's mental continuum and, opposite to that, start to come together, without alternating, then one can consider that one's vipaśyanā practice has completed the Madhyamaka analysis. In Tsongkhapa's words:

When they come together [emptiness of inherent nature and dependent origination], no longer alternating,

Just seeing dependent origination in a non erroneous way

Destroys how the object is grasped by wrong apprehension,

Then one's analysis of the view is complete. (Lam gtso nam gsum $)^{2}$

2 Our translation. 
In this sense, differently from the context of the European philosophical tradition, in the context of Tsongkhapa's treatise, a complete critique of his ideas would actually require the personal practice of the meditation according to his instructions, since this is the only way to truly evaluate whether or not his instructions do lead to the generation of that philosophical view that he claims to be not only necessary but also possible. In spite of that, there is still a broad field of opportunities for the philosophical debate as we know it in European philosophy, since it is always possible to present arguments that attempt to invalidate the arguments used by Tsongkhapa as instructions to be applied in meditation. And it is in this field exactly that he debates with his contemporaries.

According to Tsongkhapa, those mistaken 'philosophical' mental positions, that means, those mental positions which still find themselves under the influence of the root delusion marigpa in Tibetan (Sanskrit: avidyā) - also manifest in the form of philosophical systems of tenets. Therefore, this is the perspective from which he treats his opponents. Moreover, as he describes how those mental positions alternate in the process of the meditation itself, he points out that the most important opponent that must be defeated is the one that ordinarily manifests in our own mind, that is, the one that naturally manifests in the mind of those who set forth to put into practice his instructions. This is the main 'opponent' that is supposed to be taken as a target of the whole chain of arguments raised along Tsongkhapa's presentation of emptiness.

The last thing that must be clarified in this introduction is the fact that, although in the course of our attempt to achieve some level of comprehension of the first treatise in which Tsongkhapa presents his explanation of selflessness, we have been led to the study of some Buddhist articulations and concepts which were actually first formulated by other Buddhist philosophers, like Nāgārjuna, Candrakīrti, Dharmakīrti etc, our presentation of such articulations in this thesis is limited to the way in which they are understood in Tsongkhapa's treatise analyzed by us and in the manuals used by the Buddhist lineage founded by him (the Gelug) which were also taken as a source of relevant information for our research.

Therefore, our reader should not expect to find in this work any attempt to confront Tsongkhapa's understanding of his philosophical background with the original writings of such Indian Buddhist masters. In this sense, the reader should know beforehand that whenever Nāgārjuna 's or Dharmakīrti's ideas are mentioned by us, we are actually speaking of Nāgārjuna or Dharmakīrti as seen by Tsongkhapa. The same is valid regarding all other Buddhist authors and ideas mentioned in this work. The chapter named 'General Buddhist Ontology' does not refer to a 
general Buddhist ontology found by us as a result of an exhaustive study of all Buddhist writings, but solely to the way in which the Gelug manuals studied here depict some basic ontological notions which, according to such manuals, are accepted by all authentic Buddhist philosophical systems of tenets. The same is valid for the chapters 'Dharmakīrti's ontology' and Dharmakīrti's epistemology'. Although we have included in our research the study of some of Dharmakīrti's texts which have been translated into English, we have limited our presentation of Dharmakīrti's ideas to the way in which they are explained in the Gelug manuals. 


\section{Chapter II}

\section{General Historical Introduction to Buddhist Philosophy}

Before we start with our attempt to describe and discuss some of the key concepts of what is nowadays generally known as 'Buddhist philosophy', it is important to draw the reader's attention to some of the characteristics which constitute relevant differences between this field of intellectual inquiry and the tradition of philosophical investigation and composition of masterpieces that originated in Ancient Greece and developed throughout Europe.

The main author which our description of Buddhist philosophy focuses upon was born in Tibet in the fifteenth century and was a Buddhist monk. His philosophical writings were composed in the context of a certain tradition whose main features should be depicted here before directly approaching his philosophy. As Georges Dreyfus asserts, we may characterize Tibetan Buddhist philosophy as a sort of 'commentarial' philosophical tradition, for the philosophical inquiry developed by the Tibetan Buddhist authors is entirely based on the commentaries that they composed about the great masterpieces of specific Indian sources which they considered as authoritative ${ }^{3}$. Therefore, the study of a Tibetan author like Tsongkhapa, who is the main focus of

3 "Tibetan thinkers do not write their philosophical works based only on their personal reflections. Rather, they develop their ideas by commenting directly or indirectly on basic Indian texts. These texts are approached through a commentarial tradition that consists of a first layer of Indian commentaries and a second layer of Tibetan 
our research, requires at least some basic familiarity with the main ideas contained in those Indian Buddhist treatises upon which his writings are entirely based. However, instead of composing their texts inspired by a critical view of their predecessors' ideas, which has been the case with many Western philosophers starting with Aristotle, Tibetan Buddhist authors composed their treatises with the intention of providing the most accurate understanding of those who they considered to be the great 'way openers' of the past.

The expression 'way opener', or more precisely, 'chariot way opener', refers to those who 'cleared a path' through which 'chariots' could then run smoothly and with no impediments again. The Buddha was, of course, the first one considered by the Buddhists to have set a clean and smooth path for the 'chariots' leading to salvation. As time passed by, however, the path cleared by the great enlightened one became unsuitable as a road, due to the growing of plants that prevented the easy and adequate movement of the wheels. In other words, the misunderstandings and misinterpretations of the words of the Buddha that developed after his death made it very difficult for the seekers of salvation to put his instructions in practice correctly in order to obtain the expected results. The so-called 'way openers', then, composed extensive commentaries, with the intention of clarifying definitely the teachings of the one that they considered their ultimate master ${ }^{4}$. This tradition started in India with the great treatises composed by Nāgārjuna at the beginning of the first millennium and, after some centuries, it reached Tibet, where it continued to flourish. Tibetan Buddhist philosophy, therefore, must be approached in constant reference to the Indian treatises which it comments and whose correct interpretation it debates about.

The ultimate sources of all Buddhist philosophical schools are the teachings given by the Buddha himself. Although there is some academic controversy regarding the legitimacy of treating the historical Buddha as a philosopher, the fact that, after his death, different attempts to systematize his teachings have given rise to highly philosophical elaborations and debates along the last two thousand years is not at all a matter of dispute between scholars nowadays ${ }^{5}$. In other words, the topics and subject-matters elaborated, systematized and debated about by the so-called Buddhist schools have a lot in common with the Western tradition of philosophical reflection, deserving thus also to be called 'philosophical'.

commentaries." (DREYFUS, 1997, p. 2)

4 This explanation of the meaning of the expression 'way opener', a term which appears in Tsongkhapa's 'Great Lam-rim' translated as 'trailblazer' (TSONGKHAPA, 2002, p. 112) is verbal information taken from audio recordings of Gonsar Tulku Rinpoche's commentary of this part of the text given on the 20th of May 2007, at Rabten Choeling, Switzerland.

5 See Siderits, Mark, "Buddha", The Stanford Encyclopedia of Philosophy (Spring 2015 Edition), Edward N. Zalta (ed.), URL $=<$ http://plato.stanford.edu/archives/spr2015/entries/buddha/ $>$. 
In relation to the main differences among the Buddhist philosophical schools, we must observe first of all, that they do not refer only to interpretative disagreements, but also to the recognition of the authenticity of many discourses attributed to the Buddha. The so-called shravakayana schools accept as authentic only the teachings contained in the canon that is known as the Tripitaka, a Pali expression that means 'three baskets' and refers to three different groups of instructions which are actually accepted by all schools. The teachings are divided in those three different collections according to the main subject that they deal with, which are: 1) the VinayaPitaka, or moral code, transmitted by the Buddha to be observed by different levels of followers, ranging from the ethical principles that should be observed by the lay men and women who consider themselves Buddhists up to the very specific vows taken by the yogis and the monastic communities composed of monks and nuns; 2) the Sütra-Pitaka, consisting of different types of teachings and instructions including ethical behavior, the nature of the conditioned existence, how to free oneself from the conditioned existence, the nature of suffering and the attainment of the state beyond all suffering, the causes of suffering and the causes of happiness, the different parts that compose a human being - commonly known as the Five Aggregates (about which we will speak later) -, how to develop a perfect state of unshakable concentration, the dependent origination of phenomena and the absence of identity known as selflessness (anātman) of phenomena, as well as many other topics related also to specific advices given by the Buddha to all sorts of people that sought his guidance; 3) the Abhidharma Pitaka, which contains a more systematic, or even philosophical, elaboration of the teachings and instructions included in the two other groups.

This Canon was entirely composed by the followers of the Buddha after the death of their master. Initially, it was transmitted by oral tradition alone. The first written version arose probably some centuries after its composition, in the first century BCE (GOMBRICH, 1991, p. 77). Only the first two pitakas are recognized by all Buddhist schools as having authentically been transmitted by the Buddha himself, as they are the only sets of instructions which were compiled during the socalled First Communal Recitation (of teachings), held just a few months after the Buddha passed away. This meeting was organized by the followers of the Buddha with the purpose of compiling his instructions and form a body of teachings to be orally preserved for the posterity. The third pitaka, that is, the Abhidharma Pitaka, on the other hand, does not date from this first council. Its content, as mentioned above, is a systematic elaboration of the teachings and instructions, and more than one version of this elaboration appeared along the first centuries of Buddhism, giving rise to different schools of thought within the Buddhist community. 
The term 'Abhidharma' itself has received so far two different interpretations among the scholars. The first part of the word, 'Abhi', can be understood in two different senses. If it is taken to mean 'with regards to', then the whole expression should be translated as something like 'with regards to the Dharma' (the word 'Dharma' being translated here as 'the teachings' [of the Buddha]). On the other hand, 'Abhi' can also mean 'higher', which then renders the translation as something like 'the higher Dharma', or 'the higher teachings (of the Buddha). Noa Ronkin, in his article for the Stanford Encyclopaedia of Philosophy online approaches this second option to the sense of the Western concept of 'metaphysics' ${ }^{16}$. Differently, we have decided to use the more neutral Western notion of 'ontology' to refer to such discussions in the context of our research, so as to avoid debates about the content of the concept of 'metaphysics' and whether or not it can be applied legitimately to the philosophical elaborations found in the Buddhist treatises.

According to tradition, around eighteen Buddhist schools existed in the 3rd century BCE with theoretical differences of all types ${ }^{7}$. Along with the various versions of the Abhidarma, the second type of difference mentioned above - the recognition of the authenticity of some discourses - also arose within the Buddhist community during this period. A large body of teachings which are considered as authentically attributed to the Buddha by one great sect - the Mahāyāna - was not accepted as authentic by another sect, the shravakayana. The disagreements between those two great traditions include not only sharp philosophical distinctions, but also some other important topics which we will not analyze here. One first important aspect of those other topics, though, must be mentioned in order to clarify the meaning of the name mahāyāna. The so-called mahāyāna schools consider that the teachings and instructions given by the Buddha include not only the methods for one person to attain freedom from suffering for himself or herself, but also the methods that enable a practitioner to help more and more beings to attain the same state. Such instructions are known as 'the path of the Bodhisattva', in which a practitioner dedicates many activities to lead other beings to the state of nirvana. That is the reason why this sect received the name mahāyana, which means literally 'great vehicle' and refers to the fact that those instructions are meant to take many beings to the state beyond suffering. On the other hand, the schools which do not accept the authenticity of those instructions that teach the 'path of the Bodhisattva' affirm that the teachings transmitted by the Buddha are meant to lead only one individual person to the state of nirvana. It is important to observe, however, that both sects, mahāyanna and shravakayana, include more than one

6 Ronkin, Noa, "Abhidharma", The Stanford Encyclopedia of Philosophy (Fall 2014 Edition), Edward N. Zalta (ed.), URL $=<$ http://plato.stanford.edu/archives/fall2014/entries/abhidharma/ $>$.

7 Refer to HOPKINS, Jeffrey, Maps of the Profound, Snow Lion Publications, New York, USA., 2003; and to GOMBRICH, Richard, 'The Evolution of the Sangha', in The World of Buddhism; Thames and Hudson, London, 1991.

8 Also known as Hinayana. 
philosophical school, that is, there are important philosophical divergences between different schools which accept the authenticity of the 'path of the Bodhisattva' as well as between those who do not accept it.

As time passed by, commentaries about the Abhidharma versions as well as about the teachings of the 'path of the Bodhisattva' were also composed by Buddhists and served, together with the teachings attributed to the Buddha, as a basis for debates and new differentiations among the schools of thought. Up to the 2nd century CE, though, both compilations and commentaries about them were still anonymous. According to Gombrich (1991, p. 78), the first Buddhist authors are to be found during this period, which was also the period when the oral compilations and commentaries were written down for the first time.

The main issue around which all those schools of thought diverged, and which they all tried to elaborate philosophically according to their different principles, is the famous Buddhist concept of selflessness, or anatman. The practice of argumentative debate about the more philosophical topics also developed along with the arising of the different philosophical views, to the point that training in the art of debating became an important part of the monastic education as a whole. The tradition of the argumentative debate pervaded the history of Buddhism not only in India, but also reached Tibet and continued to develop throughout the history of Tibetan Buddhism, being kept alive up to this day. Gombrich tells us that the word $v \bar{a} d a$, which is usually translated as 'school of thought' (like in the names Theravāda, Sarvāstivāda, Pudgalavāda etc) can also be translated as (philosophical) 'view' or even as 'debate'. (GOMBRICH, 1991, p. 85)

One very important part of the instructions attributed to the Buddha by the mahayanists is the large series of texts called 'The Perfection of Wisdom' (Prajñāpāramitāa). Around the 2nd century CE, a great commentator of the Prajūāpāramitā stands out in the Indian tradition: the renowned Nāgārjuna (ca 150-250 CE). He composed many commentaries, among which the most famous one is the Mūla-madhyamaka-kārikē, which is nowadays referred to by most Western scholars as the 'MMK'. Nāgārjuna is considered the founder of one of the two main Mahayana Buddhist philosophical schools in Ancient India, whose name is Madhyamaka, and whose followers are called Mādhyamikas. The word 'Madhyamaka', many times translated into English as 'Centrist' or as 'Middle Way', refers to the fact that this philosophical school considers itself as the only one that really provides a philosophical perspective and precise explanation of the teachings of the Buddha about the 'Middle Way' (madhyamā pratipad). Nāgārjuna stated that his explanation of the crucial Buddhist concept of selflessness is a middle way between two extreme positions: reification 
and nihilism ${ }^{9}$. The exact meaning of these positions and the precise manner to define the middle path between those two extremes is a complex subject matter involving key concepts of his philosophy. The most important one is Nāgārjuna's definition of the selflessness of phenomena as being their lack of nature (svabhāva).

The first great Indian Buddhist scholar to comment on Nāgārjuna's MMK was Buddhapālita (ca 470-ca 540 CE). The original Sanskrit of this commentary has been lost, but a complete Tibetan translation has survived up to these days. Buddhapālita's commentary and interpretation of Nāgārjuna's MMK was criticized by another great Indian scholar: Bhāvaviveka (ca. 500 - ca. 578 CE). The different interpretations of Nāgārjuna's MMK offered by those two great Mādhyamikas were later on classified as two great different versions of the Madhyamaka school, and much was discussed and debated about those philosophical differences in the great Tibetan commentaries about the Madhyamaka philosophy.

The next great Indian Buddhist scholar to enter this debate was Candrakīti, who lived in the seventh century. He also composed an important commentary to Nāgārjuna's MMK, called Prasannapadā Madhyamakavrtti, which still exists both in its original Sanskrit version as well as in its Tibetan translation. Candrakīrti's commentary defends Buddhapālita's position against Bhāvaviveka's critiques. Centuries later, Tibetan scholars considered those two great authors Bhāvaviveka and Candrakīti - as the representatives of two different sub-schools within the Madhyamaka tenet system itself. The one represented by Bhāvaviveka is the 'Svātantrika school', the word 'Svātantrika' referring to the use of independent arguments (svatantra, in Sanskrit); and the one represented by Candrakīrti is known as the 'Prāsaṅgika school', the word 'Prāsañgika' referring to the commitment to use only arguments that show the inconsistent consequences (prasainga, in Sanskrit) of the opponents' statements. According to Tsongkhapa, this distinction is found in Candrakīrti's work Clear Words (Prasannapadā Madhyamakavṛtti, tshig gsal ), and is not, as many suppose, a Tibetan creation (TSONGKHAPA, 2002, p. 116) ${ }^{10}$, despite the fact that the Tibetan Buddhist literature has indeed taken this subject-matter as one of its main topics of discussion.

There were of course other great Indian Mādhyamika scholars who also contributed with important texts and compilations for the debate between the Madhyamaka and other Buddhist

9 Actually, since the Buddha himself called his method and instructions as a 'Middle Way', all Buddhist philosophical schools consider themselves as offering the right explanation of what the Buddha really meant by the expression 'Middley Way'. But only the school founded by Nāgārjuna chose to use this specific expression as its own name.

10 "Scholars of the later dissemination of Buddhist teachings to the snowy land of Tibet use the terms 'Prāsangika' and 'Svātantrika' for different types of Mādhyamikas. Since this agrees with Candrakīti's Clear Words (Prasannapadā), you should not suppose that it is their own fabrication." (TSONGKHAPA, 2002, p. 116) 
philosophical schools, like Sāntideva, Jñānagarbha Sāntarakṣita and Kamalaśīla. Śāntarakṣita and Kamalaśîla both went to Tibet to propagate the Buddhist practice and philosophy and their activities left a very important and lasting imprint in the development of Buddhist philosophical ideas and debates in Tibetan Buddhism. It is worthy mentioning here that Sāntarakṣita's main philosophical work contains a precious summary of the most important Indian philosophical schools of his time the eighth century - including both Buddhist as well as non-Buddhist doctrines. Śāntarakṣita's masterpiece along with an important work composed by Bhāvaviveka served as a basis for the formation of a genre of texts in Tibet called 'Presentation of Tenets', which include the philosophical assumptions of both Buddhist and non-Buddhist schools. Such texts have been a relevant part of typical Tibetan Buddhist monastic education up to now, being used to introduce students to the main philosophical issues which they must learn and debate about along their monastic studies. For example, Śāntarakșita's text, which is called Tattva-saṃgraha (Compendium of Principles) (translation into English in: G. Jha, The Tattvasamgraha of Śantarakșita with commentary of Kamalaśĭla, Gaekwad's Oriental Series Vol Ixxx and Ixxxiii - Baroda: Oriental Institute, 1937-9) includes a comprehensive description of many topics, like for instance: the tenet that affirms that the world has its orgin in natures or essences (svabhāva); different philosophies that explain the origin of the world from God; the Sāmkhya assumption that the physical world originated from a kind of primordial matter that they called prakrti; the tenets that affirm the existence of the self (ātman) in various non-Buddhist schools, like the Nyāya, Jaina, Sāṃkhya etc. This work also presents philosophical analysis of the concepts of substance, universals, action, language, materialism and other topics which were essential part of debate among the many Indian philosophical schools. (SOPA; HOPKINS; 1989, p. 113).

\section{MADHYAMAKA IN TIBET}

Generally speaking, all lineages and schools of Tibetan Buddhism consider themselves as Madhyamaka followers. However, exactly as there were different approaches to the Madhyamaka philosophy in India, also in Tibet the precise and correct interpretation of Nāgārjuna's MMK was since the beginning of Buddhism an important subject of debate between great scholars and 
meditators. The majority of Tibetan scholars, though, regarded Candrakīrti as their great reference for the right reading of Nāgārjuna's Madhyamaka. They all view Candrakīrti as the representative of the so-called 'Prāsañgika Madhyamaka' (mentioned above). There are significant differences, though, in the way how Tibetan scholars distinguish the 'Prāsangika Madhyamaka', represented by Candrakīrti and Buddhapālita, from the 'Svātantrika Madhyamaka', based on Bhāvaviveka's treatises.

Those differences in the philosophical interpretation of the Madhyamaka philosophy in Tibet characterize the four distinct Buddhist Tibetan schools which had their origin at the very beginning of Buddhism in that country. They are known as the Nyingma, the Kagyü, the Sakya and the Gelug Schools. The founder of this last school, the Gelug, is the great scholar Tsongkhapa, who composed important treatises about the right interpretation of the Madhyamaka and left a lasting and deep mark in the tradition of philosophical debate in Tibet as a whole.

\section{JE TSONGKHAPA}

Tsongkhapa (1357-1419 CE) composed his treatises over a period of seventeen years during which his interpretation of the Buddhist teachings developed gradually. His works have been generally divided in two great phases: the early writings and the mature writings. In the early period, he composed two important works which explore the nature of consciousness according to the philosophical writings of the Indian scholar Asanga, who is one of the main figures connected to the Indian Buddhist philosophical school known as Mind-Only (Cittamātra, Sems tsam pa). In his mature period, however, he changed his view and wrote important treatises exploring Nāgārjuna's Middle Way school (Madhyamaka, dBu ma pa) and fully supporting it, taking the commentaries provided by Candrakīrti as a basis of reference for his own presentation of the Madhyamaka.

This does not mean, however, that Tsongkhapa abandoned totally his previous philosophical position as a defender of Asanga's Mind-Only school. He continued to value the Mind-Only philosophical assumptions as a heuristic important step towards the Middle Way view. Actually, he 
did not consider only the Mind-Only school as a step towards the Middle Way, but also two other Buddhist philosophical systems - the Vaibhāṣika (Bye brag smra ba - Great Exposition School) and the Sautrāntika ( $m D o$ sde pa - Sūtra School), - were seen by him as necessary stages for the development of the ultimate correct philosophical view of reality. According to Tsongkhapa, these four systems of Buddhist philosophical tenets were taught originally by Buddha Shakyiamuni to different types of disciples. The Buddha addressed his different audiences with teachings on tenets according to their capacity of understanding and of using them correctly in the path towards nirvana. Each one of those philosophical systems of tenets serves the purpose of antidoting specific levels of misconception of reality. They form thus a sort of ascending hierarchy conceived to dissolve specific layers of wrong views.

It is important to mention that, despite the fact that this view of the different Indian philosophical Buddhist schools as constituting this ascending hierarchy is definitely a hallmark of the Tibetan philosophical school founded by Tsongkhapa, considered one of the main features that distinguishes it from the other Tibetan schools, Tsongkhapa himself never claimed it to be his own elaboration. In any case, he never presented his philosophical treatises as a new philosophy founded by him. In accordance with the Indian Buddhist philosophical tradition, he presented his treatises as commentaries that analyze the work of the great Buddhist masters of the past, whose philosophical articulations Tsongkhapa's treatises intend to defend: Nāgārjuna and Candrakīrtiti.

Tsongkhapa's mature phase started with his famous Great Exposition of the Stages of the Path to Enlightenment (Byang chub lam rim che pa), which was composed in 1402, and then continued with the following treatises: Essence of Eloquence (Legs bshad snying po) in 1408, Ocean of Reasoning (Rigs pa'i rgya mtsho) in 1407-1408, Medium-Length Exposition of the Stages of the Path (Lam rim 'bring) in 1415, and his last composition, Elucidation of the Intention (dGongs pa rab gsal), in 1418. In all these works, Tsongkhapa discusses in details the differences between the Buddhist philosophical schools, providing many arguments to defend the Madhyamaka tenets against all the criticism that it had received from its opponents along centuries.

The school founded in Tibet by Tsongkhapa's works, the Gelug, stands out as the one that utilizes deep philosophical rational analysis as an essential part of the method to attain nirvana, or full freedom from the causes of suffering. A debate has originated between different Buddhist traditions regarding whether or not the final cognition of reality, which is supposed to free oneself from all causes of suffering, can be attained without the practice of rational philosophical analysis or not. The Zen (Ch'an) Buddhism tradition, for instance, defends the idea that in order to attain 
liberation from freedom, rational analysis is not at all required; rather, nirvana is attained through the practice of mediation alone. Tsongkhapa's position supports the opposite conception. According to him, the development of the correct view of the ultimate nature of phenomena, which is the actual means to dissolve the causes of suffering in one's mind, requires both meditative practice as well as rigorous rational analysis.

It is only after the Buddhist practitioner attains what Tsongkhapa calls 'inferential knowledge' about the nature of reality, that it becomes possible for him or her to pursue a direct meditative cognition of it. This whole process which supposedly leads a meditator trainee from ordinary mistaken conceptions to correct and direct cognition of reality depends thus first of all on study and analysis, and only after that, meditation can then be applied. According to Tsongkhapa, "Only reasoning distinguishes what is or is not true" (TSONGKHAPA, 1987, p. 87). In his Great Exposition of the Stages of the Path, he says: "There are various positions on the use of scriptures in debate - some accept it and some do not; among those who accept it, there is disagreement about what requires interpretation. Hence, you must use reasoning to prove things." (TSONGKHAPA, 2002, p. 297)

But what exactly does the expression 'reasoning' mean in the context of Tsongkhapa's Buddhist philosophical writings? What kind of theory of knowledge serves as a basis for his conception of rational analysis and inferential knowledge? Moreover, how does Tsongkhapa apply knowledge obtained by rational analysis to sustain the Madhyamaka thesis that phenomena do not possess 'inherent natures' (svabhāva)?

As we attempted to accomplish a thorough analysis of Tsongkhapa's first treatise about the correct view of the ultimate nature of phenomena, the 'vipaśyanā' (lhag mthong) part of the Great Exposition of the Stages of the Path (Byang chub lam rim che ba), the need to find precise answers to the aforementioned questions, as well as to other important topics, led us to the study of Tsongkhapa's philosophical background. Before becoming a teacher himself, he studied with masters from different Tibetan Buddhist traditions, and acquired with them some fundamental philosophical views which were widespread in Tibet during that time ${ }^{11}$. Therefore, before starting with the presentation of Tsongkhapa's first composition about the madhyamaka ( $d b u$ ma pa), which

11 The five great Indian treatises that Tsongkhapa studied following the advice of one of his main teachers were 1) Ornament for Clear Realization (Abhisamayālamkāra) by Maitreya; 2) Commentary on [Dignāga's] "Compemdium on Valid Cognition (Pramānavārttika) by Dharmakīrti; 3) Supplement to [Nāgārjuna's] "Treatise on the Middle (Madhyamakāvatāra) by Chandrakīti; 4) Treasury of Manifest Knowledge [Abhidharmakośa] by Vasubandhu; 5) Aphorisms on Discipline (Vinayasūtra.) by Gunaprabha's. (HOPKINS, 2008, p.13-14) ; All these Indian treatises were adopted as a fundamental part of the education in the Gelug monasteries. Refer to note 4 further down. 
is the main subject matter of our thesis, we must clarify some fundamental key concepts which are prerequisite for the approach of his masterpiece. 


\section{Part Two}

\section{Je Tsongkhapa's}

\section{Philosophical Background}




\section{Chapter I}

\section{Introduction}

We took as our guideline for this part of the research the program of education that has been adopted by the monastic institutions connected to the lineage founded by Tsongkhapa, which are known as 'Gelug'12 monastic colleges. Tsongkhapa's presentation of 'selflessness', or ' emptiness', is studied only after some fundamental preparatory philosophical topics have been thoroughly learned. Before the main great philosophical treatises are approached, at least three years are spent in the acquisition of some basic ontological and epistemological notions, as well as in the intense training in philosophical debate ${ }^{13}$.

Traditional Gelug education starts with the study of a genre of compositions known as 'Collected Topics on Valid Cognition' (tshad ma'i bsdus grva). Those texts contain introductory lessons on basic ontological assumptions and epistemological notions. Among other subjects, they

12 Our use of the expression 'Gelug' throughout this thesis does not have the intention of affirming that all the monastic or non-monastic institutions - both from the past and present - that identify themselves with this name do actually represent a perfect unity of ideas. Such a statement would certainly require a much broader research than this one. George Dreyfus' study of the different Tibetan interpretations of Dharmakirty's treatises, for instance, does point out some subtle differences among the main Gelug thinkers of the past (refer to Dreyfus, 1997, p.178, 303, 374-77 etc), besides describing in details the main divergent perspectives between the Gelug and the other Tibetan views of Dharmakirty's epistemology. Those subtle differences among Gelug thinkers pointed out by him, however, do not affect the general explanation of the Gelug epistemological approach that is presented here and that serves the purpose of providing the necessary philosophical basis for the analysis of Tsongkhapa's treatise about selflessness.

13 For a comprehensive explanation of all the phases of the Gelug Curriculum, see NEWLAND, Guy, 'Debate Manuals (Yig cha) in dGe lugs Monastic Colleges' in Tibetan Literature: Studies in Genre, Snow Lion; USA, 1996, 
define the relationship between perception and thought, how the mind apprehends its various objects of cognition, what kinds of cognition are correct or false and, finally, which types of reasoning are valid and lead to correct conclusions. Such contents are drawn mainly from the Pramānavārttika (Comentary on [Dignaga's] Compendium on Valid Cognition - Tshad ma rnam 'grel) by the Indian Buddhist author Dharmakīrti ${ }^{14}$ (NEWLAND; GUY, 1996, p. 207). The original work that is the ultimate source of inspiration for all the ulterior Gelug 'Collected Topics' compositions is a text that was written by Tsongkhapa himself. A Door of Entry to the Seven Treatises ( $s D$ bdun la 'jug pa'i sgo), Tsongkhapa's personal explanation of Dharmakīrti's epistemology, is considered as the main reference for the Gelug formulations of basic ontological and epistemological conceptions (KLEIN; 1991, p.24). This preliminary phase of the curriculum is seen as absolutely necessary for advancing further into the study of the Madhyamaka texts, as it provides the basic conceptual tools and information without which many of the philosophical reasonings, arguments and debates contained in those other works cannot be properly approached.

\section{Generally speaking, the 'Collected Topics on Valid Cognition' (tshad ma'i bsdus grva)} manuals are divided in three parts. The first one, which is known just as 'Collected Topics' ( $b s d u s$ grva) ${ }^{15}$, usually contains lessons about the different types of existent phenomena (under the title

pp. 202-216. We mention here only the main topics of study and the length of time generally spent in each one of them: 1) fundamental notions of ontology, epistemology, logic and psychology, using Tibetan "Collected Topics" compositions (bsdus grwa) which are based on Dharmakīrti's Pramānavārttika and other sources; this phase usually lasts from three to six years; 2) the Bodhisattva path and other related subjects, using mainly Maitreya's Abhisamayālamkāra and some Indian and Tibetan commentaries; this phase usually lasts from five to seven years; 3) Madhyamaka (dbu ma) philosophy, using principally Candrakīti's Madhyamakāvatāra (Supplement to [Nāgārjuna's] Treatise on the Middle Way) and commentaries by Tsongkhapa; this phase usually lasts four years; 4) Abhidharma, based mainly on Vasubandhu's Abhidharmakośa (mNgon par mdzod) and some commentaries; this phase usually lasts four years; 5) Discipline (vinaya, 'dul ba), based mainly on Gunaprabha's Vinayasūtra.

14 It is still a matter of debate between contemporary scholars whether the Indian Buddhist philosopher Dharmakīti lived in the seventh or the sixth century CE. The fact that he wrote the Buddhist treatises about epistemological topics known as The Seven Treatises on Valid Cognition, however, is unanimously accepted. His main work is an explanatory commentary of another great Indian Buddhist philosopher, the first to ever elaborate a Buddhist epistemological theory: Dignāga (c. 480-c. 540 C.E.). Dharmakīrti comments and re-elaborates Dignāga's main ideas about the forms of valid knowledge produced by the human experience. The Seven Treatises on Valid Cognition are: 1) Analysis of Relations (sambandhapariksā, 'brel pa brtag pa); Ascertainment of Valid Cognition (pramānaviniscaya, tshad ma rnam par nges pa); Commentary on (Dignāga's) Compendium on Valid Cognition (pramānavārttikakārikā, tshad ma rham 'grel gyi tshig le'ur byas pa); Drop of Reasoning (nyāyabinduprakarana, rigs pa'i thigs pa zhes bya ba'i rab tu byed pa) - English Translation: Th. Stcherbatsky, Buddhist Logic. New York: Dover Publications, 1962; Drop of Reasons (hetubindunãmaprakarana, gtan tshigs kyi thigs pa zhes bya ba rab tu byed pa); Principles of Debate (vādanyāya, rtsod pa'i rigs pa); Proof of Other Continuums (samtānāntarasiddhināmaprakarana, rgyu gzhan grub pa zhes bya ba'i rab tu byed pa). This list, as well as the translation of the titles into English, is found in Cutting Through Appearances, SOPA, Geshe Lhundup; and HOPKINS, 1989.

15 Regarding the meaning of the Tibetan expression bsdus grva, acording to Onoda, it may have its origin in the sentence "the class where many arguments are summarized together" - rig pa'i rnam grangs du ma phyogs gcig tu 
'established bases' - gzhi grub), categories and particulars (literally, 'general and instances' - spyi dang bye brag), cause and effect (rgyu dang 'bras bu), relations and contraries ('brel ba dang 'gal $b a$ ), different types of logical negations ( ma yin dgag dang med dgag) and some other topics. The second part, known as 'Types of Minds' (blo rigs), focuses more specifically on epistemological issues, such as definitions of valid and invalid cognition (tshad ma dang tshad min), of valid direct perception (mngon sum gyi tshad ma) and valid inference (rjes su dpag pa'i tshad ma), the different types of cognition, the validity of inferences, the different types of inferences and some subdivisions of those topics. The third part, called 'Signs and Reasonings' (rtags rigs), concentrates on the types of reasons that can be used legitimately in valid inferences. In this part, we find definitions of the so-called 'three modes' criteria (tshul gsum) used to distinguish between valid and invalid reasons (literally, 'signs' - rtags $)^{16}$.

One of the most commonly adopted 'Collected Topics' philosophical manuals in the Gelug colleges is the one that is usually referred to as Yongdzin Dura (Yongs 'dzin bsdus grwa) ${ }^{17}$ (ONODA, 1996, pp. 187-20). Its first part has been translated into English by Daniel E. Perdue, in Debate in Tibetan Buddhism ${ }^{18}$. An English version of long extracts of the other two subsequent parts (Types of Minds [blo rigs] and Signs and Reasonings [rtags rigs]) can be found in Pointing the Way to Reasoning, by Sermey Khensur Lobsang Tarchin Rinpoche ${ }^{19}$. We took those two existing partial English versions of the famous Yongdzin Dura, as well as the Gelug material on epistemology translated into English by Anne Carolyn Klein ${ }^{20}$, as the sources of extremely relevant assumptions, definitions and explanations about ontological, epistemological and logical prerequisites for the analysis of Tsongkhapa's explanation of emptiness ${ }^{21}$. Both the edition of Klein

bsdus pa'i grwa. See ONODA, S. 'bsDus grwa Literature' in Tibetan Literature: Studies in Genre, Snow Lion Ed.; USA, 1996, pp. 187-20.

16 For detailed information on the 'Collected Topics' genre, see ONODA, S. 'bsDus grwa Literature' in Tibetan Literature: Studies in Genre, Snow Lion Ed.; USA, 1996, pp. 187-20.

17 The name 'Yongdzin Dura' means the 'Dura' (bsdus grwa), or Collected Topics, [composed] by Yongdzin, which means 'tutor'. This collected topics manual was written by a scholar who was the tutor of the Thirteenth Dalai Lama. (ONODA, S. 1996, pp. 187-20)

18 PERDUE, Daniel E., Debate in Tibetan Buddhism, Snow Lion Publications, New York, U.S.A., 1992.

19 KHENSUR, Lobsang Tarchin Rinpoche: Pointing the Way to Reasoning, Mahayana Sutra and Tantra Press, New Jersey, U.S.A., 2005.

20 KLEIN, Anne Carolyn: Knowing, Naming and Negation, Snow Lion ed. New York, U.S.A, 1991.

21 For a more comprehensive appreciation of the study of logic and practice of debate in the Gelug educational institutions, refer also to Tibetan Logic by Katherine Manchester (Snow Lion Ed.) Besides providing a translation of Introductory Manual on Signs and Reasonings, by Pur Bu Jok Jam Pa Gya-tso, the author offers a broad overview on the differences of approach among relevant Gelug scholars on specific subjects and definitions. 
's translation as well as Sermey Khensur Lobsang Tarchin Rinpoche's one contain the original Tibetan texts, which proved very useful as we attempted to find our way among the different translation options of the Buddhist jargon available in English.

A second very important philosophical foundation that is also part of this preliminary stage is the study of texts belonging to another Tibetan philosophical genre called 'Presentation of Tenets' (grub mtha'i rnam bzhag, siddhāntavyavasthāpana). Differently from the 'Collected Topics', the 'Presentation of Tenets' genre has its origin in India. A text written by Sāntarakșita ${ }^{22}$ and a composition by Bhāvaviveka ${ }^{23}$ served as a basis for the formation of the first Tibetan compilations.

Such texts were composed with the purpose of providing a comprehensive and systematic structure that includes the most fundamental tenets asserted by the different philosophical schools, both Buddhist as well as non-Buddhist, that were flourishing in India at the time when those Indian Buddhist scholars lived. The word translated into English as 'tenet' (grub mtha; siddhānta) means literally 'established conclusion' and, according to Gön-chok-jik-may-wang-bo's Precious Garland of Tenets (translated by SOPA; HOPKINS;), it was used by the Buddha himself and appears in one important mahāyāna sūtra, where the Buddha says:

\footnotetext{
My doctrine has two modes,

Advice and tenets.

To children I speak advice

And to yogis, tenets ${ }^{24}$.
}

An 'established conclusion', as the words themselves clearly express it, refers to a thesis that has been established in a person's mind as a consequence of a process of reflection and reasoning. The Gelug presentations of those philosophical 'conclusions' asserted by different Indian Buddhist pundits do not follow a chronological order, though. Rather, their 'presentation of tenets' compositions are arranged in a systematic way according to a specific purpose. After the presentation of the non-Buddhist doctrines ${ }^{25}$, there comes the explanation of the four main Buddhist

22 Tattvasamgrahakārikā ("Compendium of Principles") by Śāntarakșita (725-788 CE) with a commentary by his student Kamalaśîla. (Gaekwad's Oriental Series Vol Ixxx and Ixxxiii - Baroda: Oriental Institute, 1937-9) - (SOPA; HOPKINS; 1989, p. 113). Both Śāntarakșita and Kamalaśîla spent some time in Tibet during the eighth century and left a lasting imprint in the development of Budhism there. Refer to note 10 in the Introduction.

23 Tarkajvālā ("Blaze of Reasoning"); See HOPKINS, J.,1996, pp. 170-186.

24 SOPA, G.Lhundup; HOPKINS, Jeffrey; Cutting Through Appearances, Snow Lion, N.Y., USA, $1989 ;$ p. 149.

25 Not all Gelug Presentation of Tenets compositions include non-Buddhist schools. Some concentrate on the presentation of the different Buddhist perspectives only. 
philosophical schools, which are considered by the Gelug as having being taught authentically by Buddha Shakyamuni. The different Buddhist perspectives are framed in such a way so as to convey a classification of the schools as a sort of 'hierarchy of discourses' about reality, or, as Dunnes ${ }^{26}$ names it, as a 'hierarchy of analyses' of reality, whose final and definitive presentation is to be found, according to Tsongkhapa, in the so-called 'Prāsanigika Madhyamaka' tenets. Within the context of the Gelug education, the study of this 'hierarchy of discourses' has a soteriological function. It is a specific gradual procedure that is supposed to lead the student step by step to generate in his or her mind the sequential mental states that break up one by one all the conditioned mistaken conceptions of phenomena, leading finally to the ultimate view of reality. The whole process is conceived as a chain of cause and effect, in which each effect generated is the necessary cause for the next stage ${ }^{27}$. The right and precise understanding of each level of philosophical articulation, including its failures and weak points, is necessary for the understanding of the level that is right above it. In this way, the different schools are conceived as composing a gradual process that goes towards one single direction and reaches its ultimate point with Candrakirti's interpretation and presentation of Nāgārjuna's $\mathrm{MMK}^{28}$. Therefore, the distinct philosophical tenets are not seen as contradictory, but rather as different levels, as mentioned above, "where more accurate descriptions of what we perceive and think supersede less accurate ones" (DUNNE, 2004, p. 53$)^{29}$.

In order for us to understand how those different tenets can be regarded as having been taught by the same person, we must consider the direct pedagogical experience in which they occurred. As it is well known, in the context of ancient Indian thought, philosophical systems were

26 Dunnes, J., Foundation of Dharmakirti's philosophy, Wisdom Publication, MA USA, 2004, p. 53

27 Actually, according to Tsongkhapa, the whole path is conceived in this way, the part of the philosophical analysis being just one of its final stages.

28 According to Dunne, this is not a new conception in the history of Buddhist philosophy and it appears clearly in the works of Dharmakīrti (DUNNE, 2004, p. 53). Whatever the case, Tsongkhapa never claimed it to be his own invention, since, as mentioned in the introduction, he does not present his philosophical articulations as being his own ideas, but rather as commentaries whose aim is to establish the correct way of understanding Nāgārjuna's and Candrakīrti's treatises.

29 A text composed by Tsongkhapa, The Essence of Eloquence (legs bshad snying po) is considered as the source of all posterior 'presentation of tenets' compositions in the gelug order ' (HOPKINS, 2003, p. 4). The complete text has been translated into English by Robert Thurman - Tsong Khapa's Speech of Gold in the Essence of True Eloquence (Princeton, N.J.: Princeton University Press, 1984). A translation of the section about the Mind-Only School is found in Jeffrey Hopkins' Emptiness in the Mind-Only School of Buddhism (Berkeley: University of California Press, 1999). This work discusses in great depth and detail the main philosophical treatises that propound both the Mind-Only and the Middle Way tenets, surveying important philosophical compositions by Asanga, Nāgārjuna, Bhāvaviveka, Shantarakshita, Kamalashila, Buddhapālita and Candrakīrti. 
composed with the single objective of serving to eliminate the wrong conceptions in the minds of disciples, since such wrong conceptions were seen as the true causes of suffering. Therefore, those philosophical systems were elaborated with the intention of correcting specific delusions in the minds of the hearers. We should remind ourselves that in the origin of this tradition, the philosophical presentations were not written; rather they were transmitted orally in a dialogue situation, that is, in a situation in which the speaker had direct access to the doubts and questions of those who were listening. It was thus necessary to present the doctrines in accordance with the capacity of the listeners. As Dunne explains it:

(A presentation that) exceeded the abilities of its audience would not remove their confusion; hence, a composition that is superior in its analytical accuracy may be inferior soteriologically in relation to a particular audience. That is, if deeply confused beings were presented with only the most accurate descriptions of reality, they would reject them out of hand, since those descriptions are so counter-intuitive as to seem preposterous to most ordinary people. Hence, to be most effective, the presentation should be tailored to the audience. In such contexts, more accessible descriptions may be taught if they help beings to eliminate at least some of their erroneous beliefs. ${ }^{30}$

The four schools described in those manuals are the following:

1) Vaibhāṣika (Bye brag smra ba), commonly translated as 'Great Exposition School' and based on the text Treasury of the Abhidharma (Abhidharmakośakārikā) by Vasubandhu.

2) Sautrāntika ( $m D o$ sde pa), commonly translated as 'Sūtra School'. Gelug manuals distinguish two subdivisions here, each one based on a different treatise: a) the Sūtra School Following Scripture (Lung gi rjes 'brangs), which is based on Vasubandhu's commentary on his own text Treasury of the Abhidharma (Abhidharmakośakārikā); and b) the Sūtra School Following Reasoning (Rigs pa'i rjes 'brangs), which is based on Dharmakīrti's Seven Treatises on Valid Cognition' ${ }^{131}$.

3) Cittamātra (Sems tsam pa), translated as 'Mind Only School'. Here, too, the Gelug systematization insert two subdivisions: a) Cittamātra Following Scripture (Lung gi rjes 'brangs), based on the writings of Asanga and Vasubandhu ${ }^{32}$; and b) Cittamātra Following Reasoning (Rigs

30 Ibid., p. 54.

31 Refer to note 5 in this chapter.

32 It should be noted here that Vasubandhu (Fourth Century) wrote texts about the major topics of debate from the 
pa'i rjes 'brangs), based on Dharmakīrti's works ${ }^{33}$.

4) Madhyamaka ( $\mathrm{dBu}$ ma $\mathrm{pa}$ ), or 'Middle Way School'. And here, again, Gelug classification adds two sub-schools: a) Svātantrika (Rang rgyud pa) Madhyamaka, translated as 'Autonomy School' and based on Bhāvaviveka's works; and b) Prāsañgika (Thal 'gyur pa), translated as 'Consequence School' and based on the writings of Buddhapālita and Candrakīrti.

According to Gon-chok-jik-may-wang-bo, the author of Precious Garland of Tenets, a 'Presentation of Tenets' manual composed in the eighteenth century, this systematization is based on the distinctions between the three wheels of the Dharma that were turned by Buddha Shakyamuni (translated by SOPA, HOPKINS,1989 p.172). This is explained in the mahāyāna Sūtra Unravelling the Thought $t^{34}$. The so-called three turnings of the wheel of the Dharma correspond to three different sets of teachings that were given by the Buddha to different types of audiences. The first group refers to the teachings on the Four Noble Truths, when Buddha taught the path to attain liberation from suffering without teaching about the emptiness of all phenomena, which is supposed to be the subtlest correct view of reality. The second set refers to the teachings on the Prajñāpāramitā (Perfection of Wisdom), when Buddha gave detailed teachings on the emptiness of all phenomena. And finally, in the third turning of the wheel, Buddha taught the Cittamātra view. Based on these three different groups of teachings, the followers ended up building the different philosophical systems of tenets, that were then classified by the Gelug in those four main categories. ${ }^{35}$

perspective of three different Buddhist philosophical schools: the Vaibhāṣika, the Sautrāntika and the Cittamātra. According to some narratives found in the Tibetan and Chinese canons, he changed his philosophical view along his career as a Buddhist meditator and thinker, a fact that explains the different philosophical perspectives found in his texts. It is still a matter of academical dispute whether all the works traditionally attributed to him were actually composed by the same person. Nevertheless, the philosophical compositions and commentaries commonly attributed to him are considered as one of the richest sources of information about the philosophical debates in India at that time, as they also present in great detail and precision the philosophical positions and arguments of those with whom his compositions debated. His texts argue both with other Buddhist as well as non-Buddhist philosophical schools. The first philosophical school whose tenets he wrote about was the Vaibhāṣika. In order to explain the Vaibhāșika's positions, he composed the very famous Treasury of the Abhidharma (Abhidharmakośakārikā), summarizing and explaining the philosophical positions defended by the mainstream Abhidharma of his time, which was the Kashmiri Vaibhāșika monastic community. Vasubandhu's Treasury of the Abhidharma (Abhidharmakośakārikā) is the only version of Abhidharma writen in Sanskrit which has reached our time. For more detailed information about Vasubandhu's life and works, see Gold, Jonathan C., "Vasubandhu", The Stanford Encyclopedia of Philosophy (Summer 2015 Edition).

33 As with Vasubandhu (note above), also Dharmakīrti's works are considered as having advocated two different philosophical schools, although not in different texts.

34 Samdhinirmocanasūtra (dgongs pa nges par 'grel pa'i mdo). Refer to Lamotte, É., 'Samdhinirmocanasūtra, $l$ 'explication des mystère (Louvin, Paris, 1935) for an edition with the Tibetan text and translation into French. The explanation about the turning of the three wheels of the Dharma is in Chapter Seven (Questions of Paramārthasamudgata) (SOPA, HOPKINS, 1989 p.172)

35 For detailed information on the Gelug genre 'presentation of tenets', refer to HOPKINS, Jeffrey, 'The Tibetan Genre of Doxography: Structuring a Worldview', in Tibetan Literature: Studies in Genre, Snow Lion; USA, 1996, pp. 170-186; or to HOPKINS, Jeffrey, Maps of the Profound, Snow Lion Publications, New York, USA., 2003, pp 217. 
As a short illustration of how this system is conceived, we present here a table based on the text Presentation of Tenets, composed by Jay-dzün Chö-gyi-gyel-tsen (1469-1546), a Tibetan Gelug Buddhist monk who became an important author, having composed books for the three most important Gelug monasteries of his time (PRESTON, 2009 p.24). In this manual, Chö-gyi-gyel-tsen describes the principal tenets of the four main Buddhist philosophical schools according to the Gelug. Some schools contain subdivisions which are not included in this table.

Chö-gyi-gyel-tsen's description introduces in a concise way seven aspects of the different tenets of each school. They are: (1) the specific characteristics that define the school; (2) the subdivisions within the school; (3) the etymology of the school's name; (4) the definition of object of cognition, or object of perception; (5) the definition of subject of cognition, or subject of perception, which is called 'object-possessor'; (6) the definition of selflessness; (7) a presentation of the methods - the path - to overcome the root misconception of reality.

Our brief table features only their diverse conceptions of selflessness. Regarding this topic, the different philosophical schools disagree basically about three points: 1) the characteristics that define the concept of 'self'; 2) whether only persons lack a self or both persons and phenomena in general lack a self; 3 ) in case it is asserted that both persons and phenomena in general lack a self, which is the type of relation between those two types of selflessness. (Preston, 2009, p. 88) Our table exposes only the divergences regarding the two first points:

1- Great Exposition School: asserts that the concept of selflessness taught by the Buddha refers to the lack of a self characterized by being permanent, unitary and independent. Only persons lack a self thus defined.

2-Sūtra School: asserts that the concept of selflessness taught by the Buddha refers to two levels of absence of a self: a) lack of a personal permanent, unitary and independent self (the same assertion as the previous school); b) lack of a self-sufficiently substantially existent personal self. A self-sufficient substantial self is conceived as a substantial self that is the owner of the parts of the person, like for example, a self that is the owner of the body, the feelings, the thoughts etc. The term 'owner' here refers specifically to two characteristics: 1) an owner is a substance that exists independently from its possessions and separately from its possessions; it is the substance to which the possessions belong; it is, therefore, an 'I', a personal identity, which exists as an entity separated 
from the parts of the person, that is, separated from the body, from the mind etc., and that exists independently from the body, from the mind etc. 2) an owner in this sense is somebody that can control his possessions, as if this personal identity were free to decide what he feels, perceives etc, controlling thus what happens to those things that belong to him.

3-Mind-only School: asserts 3 levels of selflessness: a) lack of a personal permanent, unitary and independent self; b) lack of a self-sufficiently substantially existent personal self (in the same sense as the two previous schools); c) lack of a difference of entity between the apprehended phenomenon and the valid cognition that apprehends it - as if the apprehended phenomenon and the cognitive consciousness were two different entities. This level of selflessness refers, therefore, to the lack of an ontological separation between the identity of the subject of the cognition, on one side, and the identity of the object of the cognition, on the other side. The conception of those two poles of the cognitive event as existing separately, each one with its own identity, is called 'dualistic conception', or 'dualistic appearance', of phenomena. The name of this school - Mind-Only - refers to their assertion that, as much as the appearances in our dreams are not the mind, but are not entities separated from the mind either, in the same way, the phenomena that appear to our mind are not entities separated from the mind that perceives them. This means that, for example, the appearance of a blue color as an external object separated from the mind is false, it is a delusion, it is $m \bar{a} y \bar{a}$. As we can observe, this school propounds a concept of selflessness that relates to both persons and phenomena in general.

4 - Middle-Way School (Madhyamaka): asserts 4 levels of selflessness: a) lack of a personal permanent, unitary and independent self; b) lack of a self-sufficiently substantially existent personal self; c) lack of a difference of entity between the apprehended phenomenon and the valid cognition that apprehends it; (in the same sense as the three previous schools) d) lack of an inherent nature (or own being) of phenomena. The Sanskrit term used to designate this level of selflessness is svabhāva (T: rang zhin). The notion of identity at this level is conceived as the 'own being', 'inherent being' or 'inherent nature' of phenomena. Conceiving a phenomenon as possessing an inherent being, or inherent nature, is the same as conceiving that it possesses a nature, or being, by itself, or in itself, independently of the subject that apprehends it. The Middle-Way school asserts that phenomena exist only as names and concepts. For this school, as also for the previous one, the concept of selflessness relates to both persons and phenomena in general. 
Some of the Gelug 'Presentation of Tenets' compilations are quite long texts ${ }^{36}$, more like treatises full of details than simple abbreviated manuals. However, during the first basic level of philosophical education, the texts usually studied are the more abbreviated compositions. We took as our guide for fundamental information about the Gelug reading of the different Buddhist philosophical schools two of those abbreviated manuals that have been translated into English, both mentioned above: The eighteenth century Precious Garland of Tenets by Gön-chok-jik-may-wangbo and Presentation of Tenets, composed by Jay-dzün Chö-gyi-gyel-tsen (1469-1546). The translation of this last text is found in a manual that teaches Classical Tibetan and is accompanied by the original Tibetan text, which was again here - as in the case of the 'Collected Topics' - very useful for our research.

Although our knowledge of Classical Tibetan has improved a lot during this doctoral research, to the point of allowing us to read some texts directly in the original, the truth is that the content - not the language - of most philosophical compositions is simply too dense and difficult to be interpreted without the vast scholarly background that constitutes a very important characteristic of the Tibetan Buddhist philosophical tradition. Actually, in the context of this tradition, texts were not composed with the purpose of conveying explicitly their deepest meaning to any readers that happen to have access to them, as it is the case in Western philosophy. Rather, texts were written with the intention of being used in combination with oral explanations. In the context of a class situation, when the oral explanation of the philosophical topics takes place, written compositions are meant to be used as notes for the teachers, and, of course, as guidelines for the students as well. Therefore, the philosophical conceptual network is not totally articulated in an explicit way. As Klein states it, this tradition is kept alive in the interweaving between the study of its texts and the oral explanations of their content, depending thus on "a body of knowledge available orally, and only in that form" (KLEIN, 1991, p. 37-38). We must bear in mind that, although texts have been incorporated in Buddhist practice from the first century BCE onwards (GOMBRICH, 1991, p.77), the most fundamental transmissions have remained largely dependent on the oral traditions up to this day. It may be possible, of course, to find some differences between the lineages of oral commentaries in the various Gelug monastic colleges. Nevertheless, generally speaking, the content of those oral explanations and references supposedly shows a very high level of uniformity, as it should be the case with a genuine oral tradition.

Whatever the case, what is important to clarify is the fact that the mere general

36 Refer, for example, to Maps of the Profound - Jam-yang-shay-ba's Great Exposition of Buddhist and Non-Buddhist Views on the Nature of Reality, Jeffrey Hopkins, Snow Lion Publications, New York, USA, 2003. 
understanding of a Gelug manual or treatise - no matter whether you choose to read either a good translation or the original Tibetan - always requires some level of reliance on the oral commentarial knowledge. This is the reason why most of the contemporary translations incorporate a register of the oral commentary along with the translated texts. Therefore, we have decided that, in order to guarantee the highest level of precision and objectivity in our research, and thus avoid as much as possible all kinds of subjective anachronic interpolations or personal interpretations, we should not only access the original Tibetan texts, but also include the study of reliable translations with the addition of the oral commentary provided by authentic Gelug representatives.

Besides the study of the above mentioned Gelug manuals, we have also decided that part of our research should be dedicated to the analysis and discussion of some texts by the Indian Buddhist author Dharmakīrti, whose formulations on epistemological issues play a central role in Tsongkhapa's use of inferences (rjes dpag - ānumāna) in his treatise. We have no intention, though, of comparing the original formulations of Dharmakīrti with the Gelug presentations of his concepts in their manuals. Such an enterprise is certainly beyond the scope of our project. Rather, our intention was simply to deepen our understanding of some ontological and epistemological notions that are absolutely relevant for the presentation of Tsongkhapa's ideas. With this purpose in mind, we have included in our research the study of some of the very few translations of Dharmakīrti's works available in English, as well as some major contemporary academic commentaries that discuss in depth Dharmakīrti's key epistemological elaborations. We must mention here the special contribution of Dreyfus' Recognizing Reality: Dharmakirti's Philosophy and its Tibetan Interpretation (DREYFUS, 1997). As the title of the work clearly expresses it, Dreyfus' text focuses on the Tibetan interpretation of Dharmakirti's Philosophy, presenting and discussing in depth its principal points as well as the further interpretation and development that such conceptions received in the context of the Tibetan Buddhist scholarship, including in Tsongkhapa's Gelug tradition. 


\section{Chapter II}

\section{General Buddhist Ontology According to Gelug Manuals}

We start with the most basic ontological definition that the first school in the Gelug ascendent hierarchy, the 'Great Exposition School' (Vaibhāṣika), gives of a 'thing' (dngos po, bhava). First of all, all 'things' are also 'existents' (yod pa - sat) and 'possible objects of knowledge' (shes bya, jñeya). We can also say that all 'existents' are 'things' and 'possible objects of knowledge', as well as that all 'possible objects of knowledge' are 'existents' and 'things'. In the jargon of Buddhist philosophy, these three concepts are said to be 'mutually pervasive'. This means that whatever is one is also the others. And a 'thing' is defined as 'that which is able to perform a function'. (Gön-chok-jik-may-wang-bo, translation by SOPA and HOPKINS, 1989, p.182) The expression 'to perform a function' refers to the capacity of being a cause of something else. The reference here is the famous Buddhist conception of phenomena as being 'dependently originated' (rten byung - pratityasamutpāda), that is, the idea that all phenomena always arise in dependence of a vast net of causes and conditions. Reality is a continuous change, an uninterrupted movement of arising and disappearing of infinite 'things' connected by a broad and complex network of causal relations.

For example, for a seed to grow into a sprout, it is necessary that an infinite number of conditions be present: the water provided by the rain, the heat provided by the action of the sun, the 
natural elements of the earth that serve as fertilizers etc. And behind each of those conditions we also find an infinite number of other conditions that made it possible for those phenomena to arise. Therefore, the image that we have is that of an endless succession of processes that originate one another forming a network of multiple causal relations, where no phenomenon acts as a cause only by itself, but always conjoined with many other causes or conditions. Whatever exists must exist within this causal network, and thus, by definition, be able to perform a function. 'Existents' are then classified in two basic categories: permanent phenomena and impermanent phenomena.

This basic definition of a 'thing' is accepted by all other Buddhist philosophical schools. However, only the first one - the 'Great Exposition School' - includes permanent phenomena in the category of (functioning) things. Among the examples of permanent phenomena that perform functions, we can quote the concept of 'uncompounded space', which is conceived as the 'lack of obstructing contact'. For this tenet system, this lack of obstructing contact, despite being permanent, actually performs a function: it performs the function of allowing the free movement of other things.

None of the other schools agrees with that. Although they agree with the general definition of uncompounded space as a permanent phenomenon which is characterized as the absence of obstructing contact, they distinguish between 'allowing something to occur' from actually 'causing' something. For this reason, they do not include permanent phenomena, like 'uncompounded space', in the class of (functioning) things (dngos po, bhava). In this sense, they disagree with the Great Exposition School regarding their assertion that whatever is an 'existent' is also a (functioning) 'thing' (dngos po, bhava). Opposite to that, the other schools distinguish those two concepts, affirming thus that permanent phenomena like space, although existent, do not perform any functions, do not cause anything. On the other hand, the impermanent phenomena, that is, those phenomena which arise, have a certain duration and then disappear, are all 'things' in the sense defined above. Therefore, they are all conceived as being both causes and effects within the infinite causal network composed of impermanent phenomena.

Impermanent phenomena undergo change. To be a cause and thus produce effects is actually the same as to bring about some change in something else. On the other hand, as the whole chain is conceived as beginningless, all causes have also been caused, that is, they are also effects. Therefore, both causes and effects must be, by definition, subject to change. Reality is thus a continuous transformation, and none of those phenomena within the vast network of causal relations can be thought of as a permanent substance, although many of them appear unchanging, or 
permanent, to our ordinary mind. Therefore, this impermanent continuous process of change of phenomena is hidden (lkog gyur - paroksa) from our ordinary way of perceiving things. The apparent duration of phenomena, as Dharmakīti's texts will clarify in more details in the next section, is explained by the fact that, as each phenomenon is succeeded by another phenomenon which is very similar to the previous one, they form thus a kind of stream of phenomena that appear mistakenly to us as the duration of one same entity.

As mentioned in the introduction, the epistemological conceptions elaborated by Dharmakīrti, whose writings represent the Sūtra School (Sautrāntika), have a very important role in the way Tsongkhapa explains how inferences should be used in the process of analyzing reality and gaining certitude about the ultimate selfless nature of persons and phenomena in general. Therefore, the next section is dedicated to a concise presentation of Dharmakīti's epistemological theory. 


\section{Chapter III}

\section{Dharmakīrti's Ontology ${ }^{37}$}

Despite the fact that reality is composed of temporal phenomena in continuous change, our ordinary perception of things perceives them as if they were 'permanent identities'. Dharmakīrti elaborates on that gap between the true mode of existence of phenomena as impermanent, on the one hand, and their ordinary appearance as permanent to us, on the other hand, affirming, first of all, that phenomena are actually composed of 'infinitesimal particles'. These minute particles are gathered, forming what he calls an 'aggregate' (samcita): "That which is aggregated (samcita) is a conglomerate (samuāya), and in that sense, it is a generality (sāmānya).[According to Buddhists such as Vasubandhu], one has perception of such things." (DHARMAKīRTI, Pramānavārttika, chapter 3, verse 194, in DUNNE, 2004, p.396) ${ }^{38}$ A 'generality' (sāmānya) here means that we make a single general image, or single general representation, that accounts for all the separable minute

37 The Gelug manuals consider that Dharmakīti's works defend actually two different philosophical schools, namely, the Sautrāntika ( $m D o$ sde pa), or Sūtra School, and the Cittamātra (Sems tsam pa), or 'Mind Only School'. In this thesis we shall present only the Sautrāntika aspect of Dharmakīti's philosophy. Given that our main focus is how the Sautrāntika epistemology is used by Tsongkhapa in his presentation of emptiness, we consider that the discussion of Dharmakīti as a proponent of the Cittamātra tenets is beyond the scope of our project.

38 Pramānavārttika, chapter 3, verse 194, translated by John Dunne; 'Appendix of Translations' in Foundations of Dharmakirti's Philosophy, Sommerville, Wisdom Pulbications, USA, 2004. We have changed slightly Dunne's translation of the key concept of 'sāmannya'. Dunne translates it as 'universal'. Instead, we have chosen to use the Tibetan translation of the term (spyi), that has been rendered in English as 'generality' by both Perdue as well as Khensur Rinpoche. The term 'generality', in our opinion, conveys more clearly Dharmakirti's notion of 'sāmānya' as being applicable both to what we call universals, like the concept 'three', and what we call 'identities' or 'wholes', like 'this three'. Dunne himself draws our attention to that in a footnote, saying that the word 'sāmānya' can also mean a 'whole' or 'composite entity'. According to him, Dharmakirti uses the same term for wholes as well as universals, considering that the relation of the universal to its particulars involves the same issues as the relation between a whole and its parts. 
particles that are thus 'gathered' by our act of cognition. This type of generality (sāmānya) is said to appear to us as a 'whole'. In other words, the identity that we commonly attribute to the large majority of ordinary objects of cognition, like a book, a tree or a mountain, for example, is actually a composition of countless spacial atomic entities. Moreover, not only this 'aggregated' is a composite of minute spacial particles, but it is also a composition of minute temporal particles. From the point of view of their temporal duration, the 'unities' of our ordinary perception are conceived as entities which are composed of countless phenomena that appear successively to the mind. Dharmakīrti says:

Due to a relation with other things [i.e., other particles], infinitesimal particles that are different than their own previous moments arise [from their own previous moments such as that they can produce an awareness]. In that sense, they are said to be 'aggregated' (...). (DHARMAKīRTI, Pramānavārttika, chapter 3, verse 195, in DUNNE, 2004, p.396)

Of course, these new 'infinitesimal particles that are different than their own previous moments' are not completely different from their previous moments. Rather, they are said to be of a "similar kind of aspects as the previous moments", being thus called "a similar continuity" (verbal information $)^{39}$. Because they are extremely similar to each other, it is not possible for our ordinary human mind to realize the very subtle differences between them along the different moments of perception. This gradual process of continuous change is too subtle for us to perceive it immediately as it occurs. Instead, what usually happens is that we only realize that significant changes have taken place after some time, like in the case of a sprout that has grown into a three or a baby that has grown into a child, a young boy, an adult etc. Therefore, generally speaking, the ordinary human conception of objects as single identities which have a certain duration along time is simply an illusion. This illusion is created by the natural human lack of capacity to distinguish those very subtle differences that separate the temporally different appearances to the mind, as well as the subtle differences between the minute spatial particles. We are thus deluded into believing that those objects actually constitute spatial unities and endure as identical entities throughout time. This is the first sense in which the concept of generality (sāmānya) is used.

It is also used, however, with a slightly different meaning. In his second sense, the word sāmānya denotes the kind of representational identity that is used to refer to multiple objects which are alike, classing thus two or more objects together. It can be said to correspond to the Western

39 Oral explanation given by Gonsar Tulku Rinpoche at Rabten Choeling, Le Mont Pélerin, Switzerland, on the $6^{\text {th }}$ of June 2011. Transcribed from audio recordings. Refer to note 51 in Part Three. 
notion of universal. Concepts like 'pot', three', 'book' etc. are considered as generalities (sāmānyas) in this second sense. Although in Dharmakīrti's texts the same term - sāmānya - is used for both cases described above, from now on we shall refer to those two different instances distinguishing them as 'identity-sāmānya' and as 'universal-sāmānya'.

Our cognition, first of all, transforms the flow of events into 'identity-sāmānyas", or 'wholes', that is, it transforms the ever changing processes that are actually spread over time and space, as explained above, in single entities to which one illusory identity over time and space is attributed. And following this first layer of a constructed projection, our cognition projects over those single entities the categorical structure that classifies such 'identity-sāmānyas" (or single objects) in 'universal-sāmānyas', obtaining thus a cognition like, for example, 'this is a table'.

In Dharmakīrti's ontology, both types of sāmānya are considered as fictional constructs. Such fictional categories are made up as a result of a mental work that creates single and identical synthesis on the basis of many different individual phenomena apprehended in reality. Those constructs, therefore, are not part of the reality itself. They are projected on reality as a conceptual or representational - structure. Dharmakīrti asserts that individual phenomena are those objects of perception that appear at specific positions in space and time: “... individuals occur in distinctive ways due to the time, place and modifying conditions of their occurrence." (DHARMAKīRTI, Pramānavārttikasvopajñavrtti, in DUNNE, 2004, p.346) ${ }^{40}$ Besides, they are perceived with their own individual characteristics, whatever these may be. In opposition to that, the fictional constructs, that is, the 'generalities' (sāmānya), can be observed as existing in various positions in space and time. That explains why they are 'fictions', that is, unreal, since only phenomena that exist in specific points of space and time can actually be part of the complex cause-effect network that constitutes reality. In Dharmakīrti's words:

Real things are themselves different, but in conceptual cognition they appear as if non-different in that they appear in some single form. Those things appear that way in that their differentiation is obscured by an obscurative cognition which obscures the form of something else [- i.e, those distinct real things - ] with its own form [ i.e., the form of a single image]. That obscurative cognition, although based on those different real things, has the cognitive appearance of a single object. (...) Due to the intention of that cognition, a generality (sāmānya) is commonly said to exist. But it does not ultimately exist in the way that it is conceptualized by that cognition. (DHARMAKīRTI, Pramānavārttika, chapter 1, verses 68-70, in

40 Translated by DUNNE, in DUNNE, 2004, p.346. 
DUNNE, 2004, p.339)

and:

A single generality (sāmānya) is the warrant for expressions and cognitions that construe many individuals as non-different. (DHARMAKīRTI, Pramāṇavārttikasvopajñavrtti, in DUNNE, 2004, p.342) ${ }^{41}$

The individual phenomena that constitute reality are called 'specifically characterized' (svalaksana). They are the continuously changing things within the sphere of the causally efficient network mentioned above. In opposition to that, the 'generalities' (sāmānya), the fictional constructs, are called 'generally characterized' (sāmānyalakșaṇa). Those fictional constructs are defined as permanent (nitya), non-things (abhāva) and not causally effective. They are not able in themselves to perform any functions or, in other words, they cannot produce any effects. Dharmakirti's says: “... that which is capable of function is said to be ultimately real. The other one is said to be conventionally real. They are, respectively, the particular and the generality (sāmānya).” (DHARMAKīRTI, Pramānavāarttika, chapter 3, verse 3, in DUNNE, 2004, p.392)

Although the universal-sāmānyas are created by human beings, they do have an objective basis on the flow or reality. They are build up on the basis of our experience of similarities between the effects of the causally efficient things that we perceive ordinarily. We perceive similarities in the way that those things behave and function within the broader context of their relations with other phenomena. Dharmakīrti says: "The nature (prakrti) of things is such that, although they are different, by their nature (svabhāva), some of them are restricted to the accomplishment of the same telos (artha)...” (DHARMAKīRTI, Pramānavārttika, chapter 1, verse 73, in DUNNE, 2004, p.344). And in his self-commentary to this text, he explains: “... awareness conflates those things [the particulars] and presents them as non-different. Those things conceptualized as non-different are excluded from others in that they have the same effects and causes;" (DHARMAKīRTI, Pramānavārttikasvopajñavrtti, in DUNNE, 2004, p.339) ${ }^{42}$ And he provides some examples. For instance, he speaks about the same effects that different types of wood have, like being fit to be used for "combustion" or 'housing", whereas other phenomena, like water, cannot fulfill these same functions, "just as the ear and so on cannot produce an awareness of visible form." (DHARMAKīRTI, Pramāṇavārttikasvopajñavrtti, in DUNNE, 2004, p.344-345) ${ }^{43}$ Certain plants,

41 Translated by DUNNE, in DUNNE, 2004, p.342.

42 Translated by DUNNE, in DUNNE, 2004, p.339.

43 Translated by DUNNE, in DUNNE, 2004, p.344-345. 
despite their differences in various aspects, can have the same effect of relieving fever, which then serves as the basis for them to be categorized by human beings with a specific name and concept.

Dharmakīti opposes here specifically the idea that universals, rather than being human constructions, should be considered as existing in the things themselves, and that this fact is actually what explains that certain things do produce some specific effects whereas others do not. In an attempt to refute this view, he states that the affirmation made by some thinkers, according to which there is one universal that exists as such in different things, and that this is the reason why they present the same behavior, is a totally incorrect statement. He clearly mentions the idea which he is opposing: "Someone thinks the following: 'Without a non-different entity instantiated in each instance, how could a single expression [such as 'cow'] apply to many [individual cows]? A single expression could not refer to them all ...' " (DHARMAKīRTI, Pramānavārttikasvopajñavrtti, in

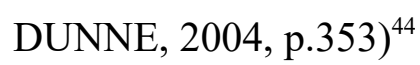

Dharmakirti's argument to negate this conception is that "the universal is without distinction." This means that, if we admit the existence of some perfectly identical qualities in different things, which would then be responsible for the sameness of certain effects produced by those things, then we would not be able to explain the fact that there are some slight differences in the effects also, like, for example, being a bit slower or quicker in the relieving of the feverish state. He says:

If the effect of alleviating fever and so on were performed through a universal, then since the universal is not distinct in any of its instances, the individuals, despite the differences in the fields where they are planted and such, would also have no distinctions, such as bringing slow or quick relief. So too, the qualities of some plants would not be better than the others. Alternatively, if the universal had some distinction in this or that instance then it would by its nature (svabhōva) be different in its various instances; hence, it would lose the nature of being a universal [which is necessarily the same in all its instances]. (DHARMAKīRTI, Pramāṇavārttikasvopajñavrtti, in DUNNE, 2004, p.345) ${ }^{45}$

44 Translated by DUNNE, in DUNNE, 2004, p.353.

45 Translated by DUNNE, in DUNNE, 2004, p.345. According to Dreyfus, Dharmakīti opposes here the Nyāya view. The Nyāya philosophy, says Dreyfus, states that for the application of a universal concept to be considered as valid, it is necessary to postulate the existence of common characteristics existing in the things themselves, on the basis of which the 'universal concept' is then perceived. For the Nyāya realistic perspective, the universals are not 'construed', but rather 'perceived' directly and immediately as the common properties of the objects of our sensory cognitions. For example, if we think of a dog as being brown, for the Nyāya, such a thought expresses two distinct entities which exist both in reality: the dog (the universal concept of dog) and the 'brownness'. See Dreyfu, 1997, p.183. 
Using the example of the universal 'cow', he explains the differences and the common characteristic between the various instances of a 'universal-sāmānya': "The essence of a Hereford is not a Jersey's $\mathrm{s}^{46}$ essence, but the exclusion from that which does not have the effect of a cow exists in both of them ${ }^{47}$." (DHARMAKīRTI, Pramānavāarttika, chapter 1, verse 139, in DUNNE, 2004, p.353)

Another reason given by Dharmakīti to defend his approach is the mere fact that the universal, being permanent, that is, always the same, cannot participate in the flow of impermanent phenomena that constitute the cause-effect relations of reality: "Also, the universal is not what perform functions because, since the universal is constant, it cannot causally support anything." (DHARMAKīRTI, Pramānavārttika, chapter 1, verse 75, in DUNNE, 2004, p.346)

Things which are not identical, that is, things which do present either slight or relevant differences in their characteristics, can be able to behave in certain ways so as to produce very similar effects. This is the reason that ultimately responds for the human categorization of such things under the same names or concepts. Therefore, these classifications can not be considered as a sign that necessarily indicates the existence of one perfect 'identity of characteristics' present on those things, which would be somehow perceived by human beings and then elaborated in the form of concepts. Despite the differences in the characteristics of things, they can indeed present a very high degree of similarity regarding specific types of behavior when they interact with other phenomena, to the point of making such human classifications absolutely valid and useful. Dharmakīrti says: “...even though they are by nature different, certain things accomplish the same function... As such, they are different from other things that do not perform that function, and they are therefore said to be non-different." (DHARMAKīRTI, Pramāṇavārttikasvopajñavrtti, in DUNNE, 2004, p.346) ${ }^{48}$

Therefore, there is something which can be considered as one 'identical aspect' of those things categorized under the same names. It is the mere fact that, considering specifically that one

46 'Hereford' translates 'sabaleya', and 'jersey' translates 'bahuleya'; the difference between them is their respective colors.

47 We should remark here that, in Dharmakirti's explanation, the factor that induces our cognition to label different phenomena under one same specific category is the exclusion (apoha) of those phenomena from the unlimited group of other phenomena which do not possess the causal potentialities to produce the same, or at least similar, effects. What makes us categorize a certain object of cognition, for example, as a jug, is the recognition that it is capable of a specific behavior (like holding water, for instance) which excludes it from the vast field of all other phenomena that are not able to perform this function or to have this kind of effect. Although this is an important aspect of Dharmakirti's epistemology, frequently analyzed by scholars, we shall not take it as an object of detailed presentation and discussions in this work, considering that, despite its pertinence - not only for the academical approach, but also from the Gelug perspective -, it is not relevant for the description of the specific philosophical aspects of Tsongkhapa's background that need to be discussed before approaching his presentation of emptiness.

48 Translated by DUNNE, in DUNNE, 2004, p.346. 
function which those things are expected to perform in a similar way, they are all different from all other things that do not present this possibility. Dharmakīrti says: "But even though things are different, it is not contradictory for them to have an exclusion from that which does not fulfill the [expected] purpose. Hence, let us consider this non-difference of the things (artha) to be the cause of the non-difference of the expression applied to them" (DHARMAKīRTI, Pramānavārttikasvopajñavrtti, in DUNNE, 2004, p.355)" objects, a non-difference of the expression used for those things does not make any sense. Therefore, we accept that the capacity to perform the same effect is the difference from that which does not have that effect." (DHARMAKīRTI, Pramānavārttika, chapter 1, verse 140, in DUNNE, 2004, p.353)

Dharmakīti explains that this active cognitive process of subsuming phenomena which are non-different regarding some or many aspects of their behavior into 'universal-samanyas' has the effect of making human beings believe that those artificial categories are actually the real phenomena which are being perceived and dealt with. That means that, not aware of the subtle mental operations at stake, ordinary human beings very easily take the generalities - both universals and wholes - as if they were the real things, not perceiving at all the fact that they are construed by the mind and applied to phenomena which are actually much more subtle and complex than the mental constructions which are projected on them.

The reason why such generalities are projected onto phenomena is the fact that we humans need them in order to successfully engage in practical activities. Dealing with phenomena as tools with which we can become involved in certain activities, we easily mistake the phenomena for the generalities under which we are able to cognize primarily their aspects that are functional according to our specific purposes. In this respect, Dharmakīti clarifies how this happens:

The image which appears to the conceptual cognition seems to be external, singular and capable of function, even though it is not capable of it. It appears in this way because persons engaged in practical activity proceed by imagining that an aspect of a conceptual cognition is that way [i.e., external, singular and capable of function]. Otherwise, it would not be possible for them to engage in practical activity. (...) Therefore, although those appearances are not real in themselves, conceptual cognition presents them as if they were; and one thus forms conventions for generalities and co-referentiality even though the object of these conventions is false. (DHARMAKīRTI, Pramānavārttikasvopajñavrtti, in DUNNE, 2004,

49 Translated by DUNNE, in DUNNE, 2004, p.355. 
$\mathrm{p} 347)^{50}$

Therefore, it is the practical activities and aims of human beings the factor that ultimately determines how the categorical structure is construed and what kind of categories and classifications are applied to the diversity of phenomena. The names utilized by languages are a reflection of this categorical network. As Dharmakīrti says:

In order to point out that the things in question perform the [desired] effect, the ancient ones assigned the same expression to those things which, although different, performed the same function; the semantic cause of that expression is the exclusion from that which does not have that effect. (DHARMAKïRTI, Pramānavārttika, chapter 1, verses 137-138, in DUNNE, 2004, p353)

He clearly states that real things, in their complexity, are unique, and that thus, the direct perception by humans of universals existing in the things themselves cannot be the reason why languages use universal concepts: "The ancient ones did not assign the same expression to a real universal-samanya because all things are situated on their own svabhāva (nature)" (DHARMAKīRTI, Pramānavārttika, chapter 1, verses 137-138, in DUNNE, 2004, p.353) Moreover, he insists that the universals used in languages and thought have their origin in the sameness of certain effects according to very specific human purposes. There is no other origin and explanation for the categorical structure found in languages than the practical goals of those human beings who are involved in using those languages. He says:

... a person applies expressions to something with some purpose in mind. That is, if different things are useful for one function, persons concerned with that function definitely should express that efficacy of those things with regard to that function. If one were to express that efficacy individually [i.e., with an expression for each particular], it would be extremely difficult to communicate. And in any case, it is not possible to express the unique essence of a particular ${ }^{51} ;$ (...) Instead, that person using language or concepts should just express those objects that are capable of that function. (...) Therefore, it is simply by virtue of the speaker's intention that one expression could refer to many things... (...) ... it is not impossible for that one expression to be used for all those things because the capacity to refer to things depends on the speaker wishes [or needs].

50 Translated by DUNNE, in DUNNE, 2004, p.347.

51 Underlined emphasis added by us. 
The example used by him is the concept 'water-jug'. A water-jug is a composite constituted by different parts, like the base, the top, the lip etc. Those different components, when united in a certain way, constitute a "conglomeration (samuha), continuum (santāna) or state (avasthtā)", in which those various parts together are able to perform one single function, like holding water. Together, they accomplish that same telos (artha). We can think of a car, that is made up of so many different components, like the wheels, the engine, the steering wheel, the seats etc., each one of which is also made up of countless components. When all those parts are gathered in a certain way, they perform one specific function, which is then the cause responsible for the fact that we, humans, cognize all those objects together as a single unit, to which a single name is then given: car. Dharmakīrti says: "The expression 'water-jug' is used in the singular to indicate that those particulars [i.e., the many particulars that compose it] have the causal potential to together produce the same effect. Or else, the singular is dependent on linguistic convention (samketa)." (DHARMAKīRTI, Pramānavārttikasvopajñavrtti, in DUNNE, 2004, p358) ${ }^{53}$

The same explanation is also used to account for the existence of names that indicate what we can call 'negative properties' in phenomena, that is, names that express a negation of somethings' ability or capacity to have certain effects or behaviors. The examples given are 'impermanence', 'selflessness' (anātma), 'unowned' and 'empty'. Dharmakīrti explains that such words convey their meanings through first "inducing in cognition an image that is intended in accord with the interlocutor's concepts and then excluding that image." (DHARMAKīRTI, Pramāṇavārttikasvopajñavrtti, in DUNNE, 2004, p359) ${ }^{54}$

With regards to the linguistic distinction between substance and predicate, Dharmakīrti states that it is a fiction created by the human cognitive processes, and does not, therefore, correspond to ontological differences actually perceived in things. According to him, such categories are created with the purpose of expressing specific aspects of the real things. In this sense, speaking about the conceptualization of qualities as separate from the entities that they qualify, he affirms that "Those conceptual cognitions [qualities] ... are based on the experience of an aspect (bheda) of the real thing." (DHARMAKīRTI, Pramānavārttikasvopajñavrtti, in DUNNE, 2004, p. 348) (55 $^{2}$ And: “... svabhāvas (natures) are conceptualized as being by nature different from

52 Translated by DUNNE, in DUNNE, 2004, p.354.

53 Translated by DUNNE, in DUNNE, 2004, p.358.

54 Translated by DUNNE, in DUNNE, 2004, p.359.

55 Translated by DUNNE, in DUNNE, 2004, p.348. 
each other and from the subject of which they are predicated..." (DHARMAKīRTI, Pramānavārttikasvopajñavrtti, in DUNNE, 2004, p. 349) ${ }^{56}$. In such cases, what happens is that one aspect is taken as a specific object of cognition, which then causes the cognitive process to operate a distinction between a subject and a predicate. However, says Dharmakirti, despite the fact that "a conceptual cognition involving a subject-predicate construction appears in such a way that it seems to be differentiated (...) [that] cognition is not differentiated due to some differentiation in the real thing." (DHARMAKīRTI, Pramānavārttikasvopajñavrtti, in DUNNE, 2004, p. 351) ${ }^{57}$ Rather, those distinctions that appear in languages are established by the cognitive activities of the human mind, or, as he states it, they "are drawn by means of conceptual differences that appear in cognition as predicates...” (DHARMAKīRTI, Pramānavāarttikasvopajñavrtti, in DUNNE, 2004, p. 352) ${ }^{58}$

56 Translated by DUNNE, in DUNNE, 2004, p.349.

57 Translated by DUNNE, in DUNNE, 2004, p.351.

58 Translated by DUNNE, in DUNNE, 2004, p.352. 


\section{Chapter IV}

\section{Dharmakīrti's Epistemology}

From the point of view of the ultimate ontological explanation of phenomena, as we have seen, Dharmakīti's texts establish a radical distinction between the 'specifically characterized' (svalaksana) and the 'generally characterized' (sāmānyalakșaṇa). As explained above, reality itself is constituted of the 'specifically characterized', which are individual phenomena located at specific instances of time and space. The 'specifically characterized' are the continuously changing phenomena (existents) which are, essentially, causally efficient, while the 'generally characterized' are the fictitious constructs projected on reality in accordance to specific aims.

Dharmakīrti's epistemological articulations affirm that, in a direct correspondence with the 'specifically characterized' and the 'generally characterized', there are also two distinct types of 'valid cognition'. He distinguishes them in the Nyāyabindu (Drop of Logic) as "direct and indirect (perceptive and inferential) cognitions" (DHARMAKīRTI, translated by Stcherbatsky, 1993, vol II; $\S 3$, p. 12). When defining their respective objects, he states that the object of the direct (perceptual) cognition, “... is the particular (svalaksana)" (DHARMAKīRTI, translated by WAYMAN, 1999, $\S 13$, p.45), while the object of the indirect cognition is the "generality character (sämānyalakṣana)" (DHARMAKīRTI, translated by WAYMAN, 1999, §16, p. 45). This same distinction appears also in his Pramānavārttika with a different terminology: 
Valid ${ }^{59}$ cognitions are of two kinds because there are two kinds of objects. There are two kinds of objects because some objects are capable of function while others are not. (...) There are two objects because some are similar across instances and others are not similar;" (DHARMAKīRTI, Pramānavāāttika, chapter 3, verse 1, in DUNNE, 2004, p. 391; Pramānavārttika, chapter 3, verse 2, in DUNNE, 2004, p. 392)

As explained above, the objects which are capable of function are the specifically characterized, which are unique, while the objects which are similar across instances and not capable of functioning are the generally characterized ones.

The expression 'valid cognition' translates here the Sanskrit word 'pramāna'. The root 'mā' means 'to ascertain' or 'to know with certainty', that is, to know, or to cognize, with no possibility of mistakes or errors (DUNNE, 2004, p. 17; and DREYFUS, 1997 p. 287). And the prefix 'pra' can have different connotations, among which we find 'the best', 'the perfect or excellent' (DREYFUS, 1997 p. 287). This Sanskrit term have so far received different renderings in English. We have chosen to use 'valid cognition', following the most common Gelug translation found in their philosophical texts available in Western languages.

In the context of Dharmakīrti's ontology, as seen above, identifying correctly an object means identifying it correctly in accordance with the type of functionality or behavior that it is expected to present. For example, if you identify a certain object in a non-deceptive way as fire, it will burn wood and be extinguished by water. On the other hand, if you identify it deceptively as fire, when you put it close to the wood, it does not burn it, and if you throw water on it, this does not have the effect of extinguishing it. In other words, it is only by the way that this object behaves when in causal relation with others that its 'nature' can be truly determined. The real and only possible criterion to decide about the 'nature' of any given object of cognition is the experience that shows concretely what kind of effect, or functionality, such object presents.

An incorrect or invalid cognition, in its turn, is the one that misidentifies the nature of the object. A classical example of an invalid or incorrect cognition used by most authors is the case when, perceiving a certain object under a very unclear light, we wrongly identify it as a snake when it is actually a rope. The cause-effect potentialities, or the functionality, of those two objects - the

59 Dunne translates the Sanskrit term as 'instrumental cognition' instead of 'valid cognition'. Here, again we have chosen to follow the tradition of how Tsongkhapa's school interprets the term, and so adopted their translation. 
snake and the rope - are essentially different. What is actually at stake is the kind of effectiveness that one expects from the object when one makes an effort to identify it, or to cognize it, in a valid way. The validity of the cognition, therefore, is actually decided by the pragmatical relationship between the cognizing event and the cognized object, or in other words, the non-deceptive character of cognitions is, ultimately, a practical matter. As Dharmakīti states in his Nyāyabindu (Drop of Logic), 15, "Because the essence of reality is just efficiency". (DHARMAKīRTI, translated by Stcherbatsky, 1993, vol II, p. 36) Dharmottara ( $8^{\text {th }}$ century), the great commentator of Dharmakirti's texts, whose explanations of Dharmakīrti's epistemology are taken as authoritative in the Gelug manuals that we have studied, says in his commentay to Dharmakīrti's Nyāyabindu: "Indeed, successful action is possible when (knowledge) has rightly constructed the object whose (existence) has been pointed out by sensation" (DHARMOTTARA, translated by Stcherbatsky, 1993, vol II, p. 11)

\section{$\underline{\text { The Direct Valid Cognition }}$}

The direct - or perceptual - valid cognition, has as its object, as mentioned before, the individual character, or the "particular", that is. "... the mental image that varies according as the object is near or remote" (DHARMAKīRTI, Nyāyabindu, 13, translated by Stcherbatsky, 1993, vol II, p. 35). Let us observe here that also in the case of a perceptual cognition, there is always also a conceptual mental process at work, since the perceptual data are subsumed under a specific conceptual category in order to produce a cognition like 'this is a rope'. Despite of that, it is called 'perceptual', due to the fact that the ultimate basis for this type of cognition is the perceptual data obtained at specific instances of time and space. Dharmottara explains it:

Direct cognition of an object in the form of a perceptive judgment is possible, i.e., (the object is really) being cognized, owing to the coordination (of an image with a point of external reality and its contrast with correlative images). Indeed, as soon as our awareness (begins to present itself as) an image of something blue, only then we can judge that we have a distinct cognition of it (in the form 'this is blue', 'it is not non-blue). It then is really cognized. (...) What imparts distinctness (to our cognitions) is a constructed image. It must be regarded as something which is called forth (in us) by the influence of (pure) sensation. But it is not itself (strictly speaking) a sense perception, because the latter is (passive), non-constructive. (...) 
... sense perception becomes a (real) source of our knowledge only in combination with a (constructed) judgment, and not (in its genuine form of) a pure sensation. (DHARMOTTARA, translated by Stcherbatsky, 1993, vol II, pp. 42-45)

\section{The Indirect Valid Cognition}

The indirect valid cognition, that is, the valid cognition corresponding to the 'generally characterized', is called ānumāna, a term which is usually translated into English as 'inference'. The Sanskrit expression 'ānumāna' is composed of two different words: 'ānu', which means 'after', and 'māna', that means 'cognition' (RABTEN, 1992 p. 57) The ānumāna is thus a cognition that occurs after something. It occurs only after another cognition, namely, after a previous cognition which is called the 'sign' (linga - rtags). 'Sign' here has the sense of 'evidence' or 'reason'. Therefore, the 'anumāna' is a cognition that occurs after a previous cognition which is actually taken as an evidence, or reason, that proves the validity of the second cognition. This previous cognition can be either a perceptual one or another 'ānumāna'. Dharmakīrti quotes two examples. First he mentions "the determination that smoke is present in a locus", referring to the inference that concludes that there is fire in a certain place due to the presence of smoke, which is then taken as the sign, or evidence. And secondly, he cites "that being produced applies to sound". (DHARMAKīRTI, Hetubindu, chapter 2, verse 13, in DUNNE, p. 412) ${ }^{60}$

Let us analyze the first example. Smoke can be taken as a sign or evidence of the presence of fire due to the fact that there is a cause-effect relation between those two phenomena. Dharmakīti says: "Smoke is established to be the effect of fire from being seen to be so just once because, were it not its effect, it would not occur even once from that which is not its cause." (DHARMAKīRTI, Pramānavāarttikasvopajñavrtti, in DUNNE, 2004, p. 335) ${ }^{61}$

We should always bear in mind that his ontological background is the concept of reality as the interdependence of phenomena, that is, there is no impermanent phenomena which could be conceived as not being produced by previous causes. In this sense, says Dharmakīrti, the fact that smoke appears when there is fire means that there is a cause-effect relation regulating such appearance. Otherwise, if we do not assume that there is such a cause-effect relation, there would be 
no explanation for the diversity of phenomena in the universe. How can we explain the diversity of things that are generated continuously in the universe, like human beings, different animals, plants, fire, smoke etc, if we don't presuppose that the differences between those phenomena are due to the fact that they are generated by different causes, by different causal complexes? He says:

The diversity of the universe would be causeless, or else anything would come from anything. Therefore, since those conclusions are unacceptable, it must be the case that the difference or non-difference of effects is due to the difference or nondifference of causes. Hence, smoke does not come from an object (artha) that is dissimilar from its observed source because one would be forced to conclude that smoke is causeless. (DHARMAKīRTI, Pramānavārttikasvopajñavrtti, in DUNNE, 2004, p. 336) ${ }^{62}$

For Dharmakīrti, the fact that a given phenomenon manifests at a specific point of time and space, and is not present at other specific points of time and space, means that its manifestation is dependent on specific causes and conditions that are not present everywhere all the time, but opposite to that, are present at very specific points of time and space here and there. Things are not present everywhere because they are conditioned by their previous causal complexes, which, in their turn are also conditioned by their previous causal complexes. Therefore, the mere fact that phenomena appear with contiguity in time, like fire and smoke, is already an evidence that there is a causal relation connecting them:

Therefore, a thing that is occurring in one time and place in distinction to another time and place where it is not occurring is dependent upon the conditions in the aforementioned time and place. In other words, its occurrence in that fashion [i.e., in a specific time and place] constitutes its dependence on the conditions in that time and place because a thing that did not depend on the causal support provided by those conditions in that time and place could not be restricted to its occurrence to that time and place. (DHARMAKīRTI, Pramānavārttikasvopajñavrtti, in DUNNE, 2004, p. 337) $)^{63}$

It is not even necessary to observe this spatial and temporal contiguity regularly. Observing it only once is enough to characterize a cause-effect connection between those phenomena: "Hence, since smoke is restricted to a specific time and place, the nature (svabhāva) of smoke is the product of that in whose time and location smoke is observed [at least] once and in whose absence it is then 
not observed." (DHARMAKīRTI, Pramāṇavārttikasvopajñavrtti, in DUNNE, 2004, p. 337) ${ }^{64}$

Phenomena thus connected are connected by their 'natures' (svabhāva). Dharmakīrti calls that connection svabhāvapratibandha ${ }^{65}$, a term that can be literally translated as 'connections (pratibandha) due to 'natures' (svabhāva). Such a connection of natures is conceived by him as a necessary link, which he calls 'invariable':

Likewise, the cause, namely fire, also has the svabhāva (nature) of producing that kind of effect. If smoke were to come from something else, then the capacity to produce smoke would not be a svabhāva (nature) of fire. Hence, fire would not produce smoke even once. (...) Hence, the relation between an effect and a cause is invariable. (DHARMAKīRTI, Pramānavārttikasvopajñavrtti, in DUNNE, 2004, p. 337$)^{66}$

However, for this connection between the 'natures' of phenomena to be considered as invariable, so as to guarantee that the conclusion produced by the inference constitutes a pramāna, that is, a cognition with certainty, with no possibility of errors, Dharmakīrti's epistemology faces an ontological issue that has been known to Western philosophers at least since the Treatise of Human Understanding by David Hume. A relation between natures that is able to guarantee the certainty of the conclusion cannot refer to a mere connection between two terms or between two objects. Rather, it must refer to a specific type of connection, the one that Hume named as 'necessary connection ${ }^{67}$.

In order for the anumānas to provide this knowledge 'with no possibility of errors', it is necessary to presuppose that the universal-sāmannyas - the generally characterized phenomena that correspond to universals - being connected in the anumāna correspond actually to specific ontological qualities, causal qualities, in all the particulars that instantiate them. In other words, it is necessary to postulate an actual ontological correspondence between the 'generally characterized

64 Translated by DUNNE, in DUNNE, 2004, p.337.

65 Refer to Nyāyabindu, $§ 20$.

66 Translated by DUNNE, in DUNNE, 2004, p.337.

67 According to Hume, a necessay connection is a connection whose opposite implies a contradiction, and which is proven or demonstrated on the level of ideas only. It is the type of knowledge that Hume described as 'demonstrative knowledge': the knowledge about relations (between ideas) which are fixed, or, in other words, that can never be altered, unless the ideas themselves are changed. For Hume, this type of necessary relations is to be found as a legitimate object of knowledge only in the field of mathematics. He defines this type of knowledge as being constituted by "mere operations of thought, without dependence on what is anywhere existent in the universe” (Hume, D., An Enquiry Concerning Human Understanding, Sec. IV, part I.) It is what Kant described as knowledge 'a priori', never contingent, but the opposite: independent of any kind of sensible contingent experience. 
phenomena' and the 'specifically characterized phenomena' so as to guarantee that the same identical ontological qualities, or causal potentialities, be present in all 'specifically characterized phenomena' that are subsumed under the same categorical sāmānyas, or 'generally characterized phenomenon'. An infallible correspondence between the conceptual structure of language, where the generally characterized phenomena are found, and the reality of the particulars must exist, or, in other words, a sort of 'correspondence between the logos and the being'.

Otherwise, if the particulars are conceived as not necessarily correspondent to the universalsāmānyas to which they are subsumed in language, in this case, the inferences based in such 'general images' cannot have any guarantee that they will function in reality, for even the slightest difference in the qualities of a particular 'fire', for example, can prevent it from producing the expected 'smoke' according to the inference that connects those two phenomena in Dharmakīrti's theory as cause and effect.

According to Dreyfus, this philosophical issue is not explicitly addressed in Dharmakīrti's writings, a fact which has left a door open for different interpretations of the ontological status of Dharmakīti's notion of sāmānya (DREYFUS, 1997, chapter 18). The empiricist description of the origin of universals (the categorical sāmānyas) conceives this origin as based on mere resemblances, as explained above. Such approach clearly leaves an open possibility for the existence of differences in the particular instances. In language, the categories are used as if they stood for identical phenomena. However, particulars are in reality merely 'similar', and not necessarily 'identical'. Dreyfus refers to this issue pointing out that it is necessary to grant some level of 'reality' to those universal types so as to provide real guarantee for the validity of inferences. That means, it is necessary to conceive the universal-samanyas as somehow present on the level of the reality itself - in the ongoing flow of dependent arising of phenomena. We must conceive the perfect identity of the svabhāvas at stake not only in language, as mere fictitious constructs, but also on the level of the real phenomena themselves. Otherwise, if they are not conceived as having any 'level' of reality, inferences cannot be seen as being able to produce knowledge with no possibility of mistakes whatsoever.

In other words, we must conceive the 'natures' of particulars subsumed under the same universal-sāmānya as a sort of formal identity, that is, as a combination of qualities that will always have exactly the same precise behavior within the universal causal network, always the same precise power to produce the same specific effects. To grant a 'nature' in the sense of a formal identity to the universals present in the inferences means to conceive them as identities that function 
in reality although they do not exist as identities in reality, that is, they do not exist as permanent identities anywhere. However, despite of that, they should be conceived as constituting some kind of formal structure that corresponds precisely to the way that the impermanent phenomena which compose reality as a universal causal network function, as if the relation between those natures formed some sort of fixed patterns, which, when abstracted from their temporal and spatial conditions, that is, when abstracted from the ongoing flow of cause-effect net, could be thought of as composing a sort of abstract fixed structure. This means that the characteristics of a given phenomenon which are responsible for its functioning in this or that way must be conceived as 'essential characteristics' as opposed to simple 'accidental characteristics' ${ }^{68}$. As Dreyfus articulates it:

... on the basis of the perception of a particular smoke, we infer the presence of a general property - smokeness - and from it the presence of another - fireness. That is, when we see a particular smoke on the hill we realize that 'smokeness' is instantiated on this hill and deduce that 'fireness' must be as well. Therefore, the inferential process starts from the particular and moves to the universal before going back to the particular. It is based on the apprehension of universals that are connected and applied to a particular-situation. (DREYFUS, 1997, p. 145)

Whether or not Dharmakīrti's definition of 'nature' can be interpreted as something very similar to the idea of 'essence' in Western philosophy is a matter of academic debate among scholars. We shall not discuss here the debate between such scholars regarding this issue. Since our purpose is rather to clarify the epistemological theory that is used by Tsongkhapa, we shall turn our attention now to the way in which the Tibetan Gelug school has approached Dharmakīrti's epistemology centuries later.

In this respect, Dreyfus tells us that, according to the Gelug reading of Dharmakīrti's theory,

68 According to Dunne, however, this should not be taken as a direct sign that Dharmakirti's notion of svabhāvapratibandha can be easily approximated to that of 'necessity'. He mentions the fact that all the properties that constitute the nature of phenomena are approached in Dharmakirti's epistemology as properties that appear as so to a specific mind and are thus dependent on mental states such as need, habituation, expectation, purpose etc. Therefore, when a person cognizes a phenomenon whatsoever, thus subsuming his sensitive data to a categorical type or universal, he does so always with an objective in mind, aiming at some activity. Dunne analyzes Dharmakirti's example of the different natures (svabha $v a$ ) that are attributed to the same phenomenon - a corpse of a dead woman - when it is seen with the different mental states and different purposes represented by three distinct cognizers: a dog, a libertine and a meditator. The dog sees this corpse as 'food', while the libertine sees it as 'a lover' and the meditator sees it simply as a dead body. Clearly these three different 'natures' attributed to the same phenomenon do not contradict each other, otherwise at least one of them would have to be considered as mistaken, or as a non-valid cognition. Nevertheless, Dunne argues that this does not allow us to attribute a relation of de re necessity between the notion of 'natures' despite the fact that the svabhāvapratibandha does imply an idea of trustworthy, infallible cognition. He suggests that it is perhaps possible to ascribe a level of de dicto necessity although this approach also needs to be used with caution. For a detailed discussion on the topic, see Dunne, John D., Foundations of Dharmakirti Philosophy, Wisdom Publications, 2004, USA, ch 3. 
the sāmānyas are not completely fictitious images. What is fictitious is the sāmānya that is constructed as a permanent and static unity that suffers no change and is utilized to subsume the individuals that do exist in the reality. This means that the specific characteristics that individuals present do exist in reality as those specific characteristics, but not as a separate permanent unity that is not part of the universal flow of phenomena. In other words, the universal-sāmannyas can only be apprehended in the impermanent particulars that instantiate them, as they do not have any existence in themselves separate from those particulars. According to Dreyfus, for the Gelug, at least some universal-sāmānyas do correspond to certain patterns of functionality; they correspond to certain patterns of qualities and causal potentialities, although such patterns cannot be considered as existing 'per se', separate from those particulars $^{69}$.(DREYFUS, 1997, chapters 9 and 10)

We can quote here at least one passage of Dharmakīrti's Pramānavārttikasvopajñavrtti that clearly supports such interpretation. When speaking about the transient nature of phenomena, Dharmakīti asserts that the impermanence of a given phenomenon is established in reality together with that phenomenon and that it can be found in more than one phenomena. This means that this universal-sāmānya 'impermanence' is found in those phenomena that instantiate them. In other words, we are speaking of a kind o property that is common to different objects of cognition. He says:

... it is not the case that impermanence and so on do not pertain to particulars. This is so because there is no impermanence other than the fluctuating thing (anyac calãd vastunah) itself. That is, one apprehends a thing which is of that kind [i.e., impermanent] to be something that endures for only an instant; hence, one has cognitions such as 'This is impermanent' or 'Impermanence pertains to this'. (...) Those conceptual cognitions are not groundless because they are based on the experience of an aspect (bheda) of the real thing. (DHARMAKīRTI, Pramānavārttikasvopajñavrtti, in DUNNE, 2004, p p. $\left.348^{70}\right)^{71}$

69 Dreyfus states that we find a clear articulation of the philosophical problem connected to the validity of the inferences in a text by Dharmottara, the outstanding Indian commentator of Dharmakîrti that lived on the eighth century and whom the Gelug school took as an authority on epistemological issues. Dharmottara points out the problem quite clearly: 'Question: if there is no (real) momentariness or anything else, how is anything to be established by a reason of nature (svabhāvahetu, rang bzhin gyi gtan tshigs)?' In other words, if the universalsāmannyas - or general images - are not conceived as corresponding precisely to the qualities of the real things that they subsume, how can the inference be trustworthy? And he gives his reply to this objection: the universalsāmannyas are classified in two different kinds, that is, we can conceive them in the following two different ways: a) as real entities which are permanent, partless and exist separately from their instances; and b) as characteristics that do not exist separately from the entities where they are found; rather, they depend on those entities to exist. Dharmottara says that the first kind of universal-sāmānya is entirely fictitious, existing only in language and thought, whereas the second kind is real and does correspond to the properties found in reality. More than this, he says that the universal-sāmannyas as defined in term b) are actually apprehended by perception. (DREYFUS, 1997, p. 200)

70 Translated by DUNNE, in DUNNE, 2004, p.348.

71 Refer also to Dreyfus, 1997, p.197. 


\section{Chapter V}

\section{Dharmakīrti's Epistemology According to Gelug Manuals}

We shall present now a very concise analysis of the Gelug most fundamental epistemological articulations of Dharmakīti's pramāna theory in order to discuss briefly how their presentation of the relation between the universal-sāmānyas and their particular instances justify and fully support the use of anumānas in the path that leads to the Buddhist soteriological goal. As we shall see, indeed, as pointed out by Dreyfus, the Gelug articulations of Dharmakīrti's epistemology conceives the universal-sāmānyas as not entirely fictitious.

Let us start with the definition of the pramāna (tshad ma) found in the most famous Gelug manual about epistemology. A pramāna, or valid cognition, is "a mind that is infallible with regards to its principal object according to the way of apprehending it." (Yongdzin Dura, in KHENSUR Rinpoche, p. 381) The first thing to be noted here is the use of the word 'infallible'. The Tibetan term ' $m i$ slu $b a^{\prime}$ means literally 'non-deceptive', in the sense of being absolutely trustworthy, flawless, unerring, with no possibility of mistakes, therefore, 'infallible'. It clearly refers to the meaning of the Sanskrit root ' $m \bar{a}$ ' in 'pramāna', which, as explained before, means 'to ascertain', 'to know with certainty', that is, to know with no possibility of mistakes or errors.

Following very closely Dharmakīrti's epistemology, the Gelug manuals also recognize two types of pramāna, the direct valid cognition (mngon sum gyi tshad ma, pratyaksapramãna) and the 
inferential valid cognition (rjes su dpag pa'i tshad ma, anumãnapramãna). In the explanation of the Sautrāntika Tenet System from the Presentation of Tenets manual by Jang-gya-rol-bay-dor-jay, translated by klein (KLEIN, 1991), we find the following definition of Valid Cognitions in Dharmakīrti's system:

Due to objects of comprehension being definite as the two, specifically characterized phenomena (rang mthsan, svalaksāna) and generally characterized phenomena (spyi mtshan, sāmānyalaksana) or as the two, manifest (mngon gyur, abhimukhī) and hidden (lkog gyur, paroksa) phenomena, valid cognizers (tshad ma, pramāna) are definite as the two, direct (mngon sum, pratyaksa) and inferential (rjes dpag, ānumāna). (Jang-gya-rol-bay-dor-jay, in KLEIN, 1991)

In the Yongdzin Dura, we find the definition of the inferential valid cognition as "a new, infallible conceptual cognition with regard to a hidden object, its object of comprehension, based on a perfect reason (rtags - literally 'sign')." (Yongdzin Dura, in KHENSUR Rinpoche, 2005, p. 219). The first thing to be clarified here refers to the meaning of the expression 'hidden object'. That is defined as "that object realized in a hidden manner by the conceptual mind grasping it". (Yongdzin Dura, in KHENSUR Rinpoche, 2005, p. 219) It is opposed to a manifest phenomenon, which is conceived as "an object realized directly by direct valid cognition" (Yongdzin Dura, in KHENSUR Rinpoche, 2005, p. 219). Generally speaking, there is no real contradiction between a hidden and a manifest phenomenon. As we will see further down, in the explanation of the concept of 'isolates', this distinction does not refer directly to the nature of the object of cognition itself, but rather to the mode, or possibility, of apprehension of different levels or aspects of objects of cognition. Therefore, it refers mainly to the mode of cognition on the part of the subjective mind.

Regarding the different types of valid inferences, the Gelug manual Analysis of Reasons, The Essence of Scriptural Authority and Logical Reasoning: A Presentation of Reasoning to Delight Scholars (rTags rigs kyi rnam gzhag lung rigs snying po bsdus pa mkhas pa dgyes byed), by Chone Lama Drakpa Shedrup (Co ne bla ma grags pa bshad sgrub) (1675-1748) ${ }^{72}$, quotes Dharmakīrti's Pramānavārttika mentioning three distinct kinds of valid reasons, or signs (rtags). They are: reason of effect, reason of nature and reason of non-observation. The first one, the reason of effect, is the one that justifies the inference which connects the existence of fire to the presence of smoke. The manual quotes again Dharmakīrti's text: "Concerning the first, perfect reasons of effect, it instructs in the same text, 'Whatever nature the cause has, without it [as a producer], its effect will not arise.' And further, 'smoke is the effect of fire', and so forth." (in KHENSUR 
Rinpoche, 2005, p. 339) The text does not discuss the cause-effect relationship itself, but rather, takes it for granted that such relations are based on the connections between natures that constitute reality, since reality, as explained before, is conceived as a vast network of causal relations. In the continuation of its description of the reasons of effect, the manual goes on providing definitions and explanations of the different types of reasons of effect, like for example, reason of effect proving a direct cause, reason of effect proving a general cause, reason of effect proving a particular cause and so on.

The second type of reason, the reason of nature, is the one which we shall now focus our attention on, since this is the type of reason used in the inferences that prove the selflessness of persons and phenomena in Tsongkhapa's text. The manual, one more time quoting Dharmakīrti's Pramānavārttika, says: "Just by having that nature, it automatically has a perfect relationship of nature.” (in KHENSUR Rinpoche, 2005, p. 364). The classical example of this type of valid inferential cognition found in the Gelug texts, which is also the one mentioned in the quotation of Dharmakīti's Hetubindu above, is the anumāna that proves sound to be impermanent. Let us describe this inference in details. As all anumānas, it is a cognitive process that includes four terms:
a) Sound is produced;
b) everything that is produced is impermanent;
c) everything that is not impermanent is not produced;
d) therefore, sound is impermanent.

According to this epistemology, we use inferences with the reason of nature because they allow us to impute predicates to objects of valid cognition when those predicates are considered as 'hidden' (lkog gyur) from our direct perception (mngon sum), as mentioned in the definition. This is the case of the impermanence of the sound, or the impermanence of any other object. All valid inferences, however, whatever type of reason they use, must comply with a specific criterion: the reason must have the 'three modes' (tshul gsum). Jang-gya-rol-bay-dor-jay says in his Presentation of Tenets: "An inference is: a consciousness which arises in dependence on its own base, a reason (sign) having the three modes, and which thoroughly infers the object being proved." (in KLEIN, 1991, p. 164) The three modes are the following:

1) property of the subject (phyogs chos): This means that the reason (sign) - being produced - must necessarily be attributed to the subject 'sound'. That is, all types of sounds are necessarily produced; there is no sound whatsoever that has not been produced. It corresponds to the content of 
proposition 'a'.

2) pervasion (rjes khyab): it is the ascertainment of a necessary connection between the reason (sign) [being produced] and the element that will be assigned to the subject-matter by means of the inference (impermanence). It can be formulated in the following way: everything that is produced is necessarily impermanent. It corresponds to the content of proposition ' $b$ '.

3) reversed pervasion (ldog khyab): it is the negative ascertainment of a necessary connection between the reason (sign) [being produced] and the element that will be assigned to the subjectmatter by means of the inference (impermanence). It can be formulated as follows: everything that is not impermanent is necessarily also not produced. It corresponds to the content of proposition 'c'. ${ }^{73}$

The content of proposition ' $\mathrm{d}$ ' is the necessary conclusion arrived at as a result of the inferential cognitive process. $^{74}$

73 A question may be raised here regarding the need of the reverse pervasion in the syllogism, since, from the ontological point of view, the pervasion and the reverse pervasion amount to the same content. According to Dharmottara, only one of them should be actually formulated in the inference. However, when one explains the syllogism formula both must be mentioned, for, no matter which one of them one chooses to use, it is necessary to observe the fact that both must not allow any exceptions whatsoever. "The following question arises. When the presence of the mark 'only' in similar cases has been stated, its 'absolute' absence in dissimilar cases must evidently follow by implication. Why is it then, that two different aspects of the mark have been mentioned? The answer is as follows. Either the positive concomitance (of the mark with the predicate) or (its contraposition, i.e.), the inverted concomitance (of their negations), should actually be used. But both must be without exception. Not otherwise. In order to emphazise (this necessity) both aspects have been mentioned." (DHARMOTTARA, translated by Stcherbatsky, in STCHERBATSKY, 1993, vol. II, p. 57) According to Perdue, however, the Gelug school presents a different approach to this point, for it considers that the pervasion and the reverse pervasion refer actually to two different types of realization. He explains it: "For any syllogism in which the sign is established as the forward pervasion, that sign will also be the counter-pervasion. Still, the values of these two types of pervasion are somewhat different. The main requirement of the forward pervasion is that the sign must exist exclusively in the similar class whereas the main requirement of the counter-pervasion is that the sign must be universally absent in the dissimilar class. Also, the ascertainment of the forward pervasion and the ascertainment of the counter pervasion are different sorts of realizations. If one explicitly realizes the forward pervasion, one implicitly realizes the counter-pervasion. And if one explicitly realizes the counter-pervasion, one implicitly realizes the forward pervasion. From this point of view, the two types of pervasions are different requirements. Although they are ontologically concomitant - for if the sign is the one then it is also the other as well - explicitly they are ascertained separately." (PERDUE, 1992, P. 49)

74 The explanation of the inference given here summarizes the long presentation found in Khensur Rinpoche's Pointing the Way to Reasoning, where he provides the translation of the classical Tibetan Gelug manual Analysis of Reasons, The Essence of Scriptural Authority and Logical Reasoning: A Presentation of Reasoning to Delight Scholars (rTags rigs kyi rnam gzhag lung rigs snying po bsdus pa mkhas pa dgyes byed), by Chone Lama Drakpa Shedrup (Co ne bla ma grags pa bshad sgrub) (1675-1748), along with the original Tibetan text and extensive explanatory commentaries given by him, an authentic lineage holder of the Gelug oral tradition (KHENSUR Rinpoche, 2005, pp 316-338). Similar explanations are also found in Jang-gya-rol-bay-dor-jay's Presentation of Tenets (in KLEIN, 1991, pp. 163-165) with oral commentary by Lati Rinpoche, Demma Lochö Rinpoche and Geshe Belden Drakpa, as well as in Geshe Rabten's The Mind and its Functions (RABTEN, 1981, chapter III). A detailed commentarial explanation of the original elaboration by Dharmakirti himself is found in Dharmottara's commentary to the Nyāya-bindu, translated into English by Stcherbatsky (STCHERBATSKY, 1994, pp. 48-68). We have not observed any relevant differences regarding the philosophical content of all those presentations of 
At this point, as the example of the ānumāna given above uses the famous Buddhist notion of impermanence, it is important to remind us briefly of why impermanence is said to be a 'hidden object' cognized first through an inference. As explained in the second section of this part, general Buddhist ontology conceives reality as an ever-changing chain of phenomena related in a universal causal network, where all causes and effects are impermanent. According to Dharmakīrti's explanation of impermanence, impermanent phenomena undergo a continuous process of disintegration from one moment to the next, maintaining thus their transitory existence in dependence on a broad net of causes and conditions. The objects that we ordinarily perceive as if they were 'identities' abiding for a certain time are actually composed of a continuous succession of atomic similar phenomena, which we mistakenly frame as the duration of one single entity. Therefore, this level of continuous transformation of things is not directly cognizable for us; it is hidden (lkog gyur) from our ordinary capacity of sense perception.

Every Buddhist tradition agrees that, because this level of reality is not ordinarily perceptible for us, the Buddha transmitted methods of meditation to train and enhance our physical and mental senses and develop our capacity of concentration so as to attain a state of perception that allows human beings to achieve a direct cognition of impermanence. However, some traditions defend the idea that the Buddha considered necessary to develop intellectual knowledge about those hidden aspects of reality, like impermanence, before attaining the full capacity of perceiving them directly by means of a very highly developed power of concentration. Dharmakīrti's epistemology with its description of the use of inferences (ānumānas) is an example of a tradition that considers the use of rational analysis as an important tool in the path towards the final soteriological Buddhist goal. This means that, long before a practitioner of meditation attains the direct view of reality, that is, the direct perception of the continuous flow of the ever changing causal network (dependent arising - pratītyasamutpāda, rten byung) which was seen, or apprehended, by the Buddha's mind, he or she should train in understanding conceptually that this is the only possible consistent explanation of reality. And this understanding is achieved through the use of anumānas that prove it.

According to the traditions that follow Dharmakirti's epistemology, and this includes the Tibetan Gelug school founded by Tsongkhapa, the conclusions arrived at as a result of the use of

Dharmakīrti's theory of the inference. According to Dunne, those basic notions about the logical structure of inferences were a common point of agreement between most Prāmana Theorists contemporary to Dharmakīrti, the disputes among them being related mainly to the more fundamental ontological assertions that serve as a philosophical basis for justifying and legitimating the validity of the inferential knowledge. 
inferences constitute non-deceptive knowledge obtained through reasoning, as we can see by the definitions above. Taking impermanence as an example, through the use of the inferences, it is possible for a practitioner to generate in his or her mind a very precise conceptual image of this subtle continuous momentary transformation of phenomena. Such conceptual image, although of course not being the same as the direct cognition of this subtle level of reality itself, is absolutely valid. It is valid knowledge because it does correspond to the actual impermanence of phenomena.

Therefore we can conclude that, for those who believe that the use of Dharmakîrti's anumānas can actually provide accurate knowledge about such hidden levels of reality like impermanence or selflessness, those concepts, or generally characterized mental images, of impermanence, being produced, selflessness etc, do correspond to very precise and fixed patterns of how phenomena exist, or behave, in the subtle levels of reality. We may say that, in those cases, the ontological problem regarding the relationship between the specifically characterized, with their uniqueness, on the one hand, and the generally characterized built upon mere similarities, on the other hand, sort of disappears. Because, since we are speaking here about the subtle ontological mode of existence of things, like in the case of impermanence and selflessness, this subtle mode of existence is precisely the same for all things, despite their uniqueness in time and space or their uniqueness regarding other characteristics. In other words, we cannot say that phenomena which are unique, because of their uniqueness, have differences in the way that they are impermanent or empty of a self. Opposite to that, those very fundamental ontological characteristics, which relate to their mode of existence, are precisely the same for all of them. No phenomenon can be said to be less or more impermanent than others, less or more produced by causes and conditions than others, nor less or more selfless than others. However, we can still ask: how does the Gelug epistemological articulations guarantee the 'infallible' character of the inferences used to realize impermanence or selflessness conceptually?

Gelug scholars formulated their definition of a phenomenon that is considered as an individuation of a given universal-sämānya in the following way. A phenomenon is an individuation of a universal-sāmānya, - or universal-generality, as it is said in Tibetan - when it is in accordance with three criteria: (1) the phenomenon must be that universal-generality; (2) the phenomenon must have a relation of same essence (bdag gcig brel) with the universal-generality; and (3) there must exist many other phenomena which are also cases of that universal-generality. The Yongdzin Dura manual says:

The definition of something's being an instance of that phenomenon (rang nyid 
chos de bye brag yin pa) is that which is observed as a common locus ${ }^{75}$ such that (1) it is that phenomenon, (2) it is related with that phenomenon as the same essence (bdag gcig brel), and (3) many common locuses of not being it [that is, the instance] and also being that phenomenon are established. (Jam-yang-chok-hla-öser, Ra-dö Collected Topics, 34a. 4-5) (in Perdue, 1992, p. 621)

Khensur Rinpoche, in his commentarial explanation of the same manual, gives the following example. If a pot is an instance of the universal-generality 'thing' (which he calls 'causally effective thing', since that is the formal definition of the concept of 'thing'), (1) it must necessarily be a thing (causally effective thing); (2) it must necessarily have the same nature (rang zhin gcig brel) as a thing (causally effective thing); and (3) there must exist many other things (causally effective things) which also have that same nature but are not pots (KHENSUR Rinpoche, 2005, p. 64), like for example, tables, rivers, stars, animals etc ${ }^{76}$.

Let us observe, first of all, that the terms 'one [same] essence' (bdag gcig brel) - used in the manual - and the term 'one [same] nature' (rang zhin gcig tu brel), used in Khensur Rinpoche's commentary of the same manual, are considered as synonyms. Two other Tibetan expressions which are used in philosophical manuals to convey the same idea are 'one [same] substance', (rdzas gcig) ${ }^{77}$ and 'one [same] entity' (ngo bo gcig tu brel) (KHENSUR Rinpoche, 2005 p. 65). Therefore, this means that all instances of a given universal-generality have the same nature (rang zhin -, svabhāva) regarding one of their aspects. In the example given above, all those phenomena like pots, rivers, stars, tables etc, are conceived as having exactly the same precise nature of a thing

75 The term 'common locus' used here will be clarified further down.

76 For a more detailed discussion on the subject, see also Dreyfus, 1997, p. Ibid., p. 171-182.

77 According to Dreyfus, the use of the term 'substance' (dravya) by Dharmakīti - which is later followed also by those who adopted his epistemology, like the Gelug school - has its origin in the vocabulary used by the Indian Nyāya tradition, whose philosophical concepts constituted the common background for the greatest part of the philosophical discussion of that period. For the Nyāya, substance is the subject, or the basis, of the qualities which exist inherently in it. The substance is also the permanent substratum that undergoes changes, and it is considered to exist independently from its qualities, even before them. Therefore, the qualities inhere in a basis - the substance that was already there. Dreyfus quotes a Nyāya philosopher: 'apprehension of substanceness is just an apprehension of having independent existence' - As a Buddhist, Dharmakirti uses the same term - dravya -but in the context of the Buddhist ontology, which, as already explained, conceives reality as a continuous flow of a vast cause-effect network. In such a context, for Dharmakīti, a 'substance' is an effective phenomenon, that is, a phenomenon that is produced by causes and conditions, and that also produces effects. The possibility of producing effects and undergoing changes is the characteristics that alone defines whatever is real or not real, and the word 'substance' is used by Dharmakīti to denote what is real in opposition to what is unreal. Real things are those which by definition have causal potentialities and therefore are able to perform causal roles. The Gelug school, accordingly, also uses the word 'substance' (rdzas), but applied only to effective phenomena, that is, to constantly changing momentary events which are causally effective, and thus considered real from the perspective of Dharmakīrti's philosophical school (DREYFUS, 1997 p. 53-57) 
(causally effective thing). And this 'same nature' that they share is also the same nature as the one denoted by the universal-generality 'thing' (causally effective thing). In other words, in the Gelug articulations of Dharmakīti's epistemology, the universal-generalities do actually represent formal identical natures, or essences, that are found in all their particular instances ${ }^{78}$. And, as pointed out by Dreyfus, those universal-generalities are not conceived as existing by themselves, that is, as permanent entities separated from their particular instances.

The fact that they do not exist as separate permanent entities is explained with the notion of 'isolates' $(\operatorname{ldog} p a)$. In the classical Gelug explanatory commentary of Dharmakīrti's epistemology, Presentation of Generally and Specifically Characterized Phenomena, by the eighteenth century great scholar Den-dar-hla-ram-ba (bsTan-dar-lha-ram-pa), we find a clear explanation of the concept of 'isolates' $(\operatorname{ldog} p a)$, as well as of how the Gelug school conceives the conceptual cognition and justifies the way in which the inferences based on the reason of 'same nature' produce valid and infallible knowledge. The concepts of 'complete engager' (sgrub 'jug gi blo, viddhipravrttibuddhi) and 'partial engager' (sel 'jug gi blo, apohapravrttibuddhi) explain how such inferences can generate genuine valid cognitions.

A cognition of direct sense data deprived of the intermediation of categorization is said to be a mind, or consciousness, of 'complete engagement'. That means that, when I see, for example, this specific desk that is now in front of me, before I even categorize it as a desk, I see it with all its specific characteristics at this point of time and space, that is, I see something with a specific color, shape, size etc. It is said to be a consciousness of complete engagement, or a complete engager, because it engages in all the factors of the phenomenon - color, shape, size etc. On the other hand, a cognition which already contains the subsuming of the sense data under a specific category, like for example, 'this is a desk', is a consciousness of partial engagement, or a partial engager, because it engages only in a separated, or isolated, factor of the sense data. In this case, it engages only in a specific aspect of the object's way of functioning or behaving, which then makes me classify it as a 'desk'. The consciousness that classifies this object of cognition as a desk does not engage in its other aspects like its color, shape, size etc. The partial engager operates through isolating specific aspects. The oral commentary added to the translation explains it:

A thought consciousness is a partial engager because it separates out, or isolates, factors contained within the same substantial entity and focuses on only one of them. (...) A consciousness which is a partial engager excludes all that is one

78 Indeed, in Tsongkhapa's treatise analyzed in Part Three of this thesis, he states that it is definitely incorrect to apprehend a 'pervasion' (a universal relation) as if it pertained only to a particular time and place. He also compares the pervasion that proves the presence of fire from the presence of smoke to the pervasion that proves sound to be impermanent because of being produced, treating those two types of inferences as having the same logical status. (TSONGKHAPA, 2002, p. 234) 
substantiality of establishment and abiding with its appearing object except for the factor being realized. (in KLEIN, 1991, p. 67)

If I think 'this desk is white', a second partial engager is added to the previous one. That means, a second consciousness that isolates, or separates, another aspect of the sense data is generated. However, the fact that thought isolates aspects in this way does not mean that those aspects exist actually in that manner, that is, separated from each other. Opposite to that, they are said to be 'one [same] substance' (rdzas gcig), 'one [same] essence' (bdag gcig brel), one [same] entity (ngo bo gcig tu brel) or 'one [same] nature' (rang zhin gcig tu brel). Another way used by the Gelug to express this idea of being of 'one [same] essence' (bdag gcig brel), one [same] entity (ngo wo gcig tu brel) or 'one [same] nature' (rang zhin gcig tu brel) is the notion of 'common locus'. Continuing with the example given above, if I add to the conception 'this desk is white' a new conception 'this desk is small', producing thus the thought 'this desk is white and small', the desk is said to be a common locus of 'white' and 'small'. Those two conceptual cognitions, the first attributing the white color and the second attributing the small size, do not emerge at the same time. Rather, they are thought consciousnesses which are generated one after the other regarding a 'common locus' as a point of reference. According to Den-dar-hla-ram-ba, due to the fact that those two conceptual cognitions arise separately one after the other, and not together, a conceptual thought considering those two - the white and the small - as separate "qualities" is generated in our mind. Den-dar-hla-ram-ba says:

When, for example, a person wishing to speak of a flower as being both an utpala and blue says 'This flower is a blue utpala', then, even though in this flower there are not two different substantial entities - the blue which is not utpala and the utpala which is not blue - with respect to the manner of expression of the term 'blue utpala', the blue and utpala emerge serially. In the same way, a thought consciousness to which the two, utpala and blue, appear to be different, develops in the [mental] continuum of the hearer. In dependence on this appearance, the single flower itself is understood to be a common locus of utpala and blue. (in KLEIN, 1991, p. 69)

This happens because when those conceptions arise - first the 'white' and then the 'small', or first the 'utpala' and then the 'blue' - they arise in a manner which is 'isolated' from all the other sense data appearing to the perception. When we think 'white', even though referring to that desk, there is no conception of its 'small size' appearing together with the 'white' in our mind. Neither in our mind nor in the mind of those who listen to our information. That is how conceptual thought 
works both in our individual cognitions as well as in the communication using language.

In the same way, when we think of sound as 'being produced' and 'being impermanent', those two conceptual thoughts are 'isolates'. This means that, although sound is a common locus of both 'produced' and 'impermanent', or in other words, although sound is 'one [same] essence' (bdag gcig brel), 'one [same] nature' (rang zhin gcig tu brel) etc. with 'produced' and 'impermanent', the concept 'produced' itself, or the concept 'produced' as isolated, does not express the concept 'impermanent', nor vice versa. When one generates the cognition of something as being 'produced', one does not generate together the cognition of that thing as being 'impermanent'. Those are two different cognitions to be generated in one's mind, because they are two different partial engagers, or two different 'isolates'. Words and thoughts are partial engagers, as the oral commentary to Dendar-hla-ram-ba's text says, "expressing or realizing only some of the factors in a single entity or common locus".

In contrast with the way conceptual cognition operates, when it is said that direct perceivers (or events of direct perception) are 'complete engagers', this means that all the factors, or all the aspects, of the perceived object appear simultaneously, and not in a series of separated knowledge events. However, the fact that, from their side, they appear simultaneously does not mean that they are understood, or realized, simultaneously. Generally speaking, to an ordinary mind, the understanding requires the conceptual operations, that means, it requires the work of the partial engagers.

Therefore, when we speak of sound being impermanent because of being produced, the ontological and epistemological assumptions which sustain the validity of such an inference refer to the conception that a mind which has developed its capacity of concentration to the utmost level becomes actually capable of realizing the subtle impermanence, or momentariness, of phenomena. And it realizes this directly, as a complete engager, with all the factors involved, that means, it perceives directly both the fact that phenomena are momentarily being produced continuously by a vast net of causes and conditions and that they are, in this way, impermanent. That is what it means to say that 'being produced' and 'being impermanent' are 'one [same] essence' (bdag gcig brel), one [same] entity (ngo bo gcig tu brel) or 'one [same] nature' (rang zhin gcig tu brel). There can be no thing which is produced but is not impermanent, or changing moment after moment, as there is no thing which is impermanent but not produced. Den-dar-hla-ram-ba states:

That which is the entity of 'produced' is also the entity of impermanent thing, and that which is the entity of impermanent thing is also the entity of 'produced'. For this reason, the two - 'produced' and impermanent - are a single entity. Yet, the 
term 'produced' does not explicitly express impermanence and the term 'impermanence' also does not explicitly express 'produced'. (in KLEIN, 1991, p. 68)

Therefore, because our mind at its ordinary level of concentration is not yet able to realize directly this subtle impermanence, or subtle continuous momentary transformation due to the continuous change of the causes and conditions, it is necessary to use inferences to generate in us a conceptual valid cognition of those truths. The inferences work with the words, that is, they work with the conventions of thought and language. That which is meant to be proven, the reason (or sign), the subject etc, or in other words, all the elements that constitute an inference, are isolates. That means, they are all conceptual cognitions that operate with the isolation of different factors, or aspects of reality. Den-dar-hla-ram-ba explains how this process happens in the inference proving that sound is impermanent. First our thought conceives the isolate 'sound'. After that, the isolate 'being produced' is added to sound. In a third moment, the isolate 'impermanent' is then added to the first two cognitions. He says:

For, when impermanent thing is established with respect to sound, then when sound is first ascertained, there is an appearance for thought of sound as if it did not exist previously and is newly established. Following that, when the two, 'produced' and 'impermanent', are serially ascertained in relation to sound, 'produced' and 'impermanent' are like (...) a white woolen cloth becoming red [in that] there is first an appearance of [sound as] produced and, following that, [as] impermanent - as if [this were] a new establishment of what did not exist previously. [However], this seriality of former and later [appearances of the establishment of sound as a produced and an impermanent thing] is not feasible with respect to specifically characterized phenomena ${ }^{79}$. For, at the mere production of sound, it is already simultaneously produced as an entity which is a produced and an impermanent thing. (in KLEIN, 1991, p. 70)

The Gelug manuals, therefore, clearly testify that, as Dreyfus stated, the Gelug interpretation

79 It is necessary to observe here that the epistemological notion of 'direct valid cognition', connected in Dharmakīrti 's philosophy to the ontological concept of 'specifically characterized phenomena,' actually contains two moments of cognition, as explained previously. The first moment is conceived as the direct apprehension of mere sense data, with no categorization whatsoever. The second moment, on the other hand, includes the subsuming of these sense data to specific categories, inducing thus judgments like 'this is blue' or 'this is a table' [refer to the previous explanation of 'Direct Valid Cognition']. Therefore, we understand that when Den-dar-hla-ram-ba says here that "this seriality of former and later [appearances of the establishment of sound as a produced and an impermanent thing] is not feasible with respect to specifically characterized phenomena", he is referring specifically to the first moment of direct valid cognition of specifically characterized phenomena, that is, to the moment when mere sense data are apprehended with no categorization. 
of Dharmakīrti's philosophical school does consider that the universals involved in the inferences used for the generation of the cognitions of the impermanence and selflessness of phenomena represent valid patterns of ontological characteristics, which makes thus such inferences absolutely trustworthy and infallible in the way that they are supposed to produce knowledge in the minds of those who use them ${ }^{80}$. In other words, according to the Gelug interpretation, such valid inferences do generate cognitions that apprehend the truth about their objects; there is a direct correspondence between their epistemological validity and the ontological truth of their objects.

However, we must still mention in our brief presentation of the Gelug basic epistemology that this correspondence between the epistemological validity of cognitions and the ontological truth of their objects does not yet exhaust the dimension of their concept of 'validity' as applied to cognitions. There is one more aspect of the Gelug conception of the infallibility of the 'inferential valid cognition' which we think it is important to add here. Geshe Rabten, a great Gelug scholar of the twentieth century, explains the characteristic of infallibility of the valid cognitions in the following way. An infallible cognition is a cognition that is "able to lead to a correct ascertainment of the object and to eliminate misconceptions regarding it." (RABTEN, 1992, p. 53) According to this definition, inferential valid cognitions must also able to eliminate all types of misconceptions about their objects. He says: "The correct inferential cognition that sound is impermanent is able to give rise to complete certainty about this fact and to leave no room for any further doubts or misconceptions concerning it." (RABTEN, 1992, p. 53) Therefore, the meaning of the word 'infallible', or unerring, as applied to both perceptual and inferential knowledge in this system, refers also to the experience of a mental state at which it is not possible to have any doubts about a given object of knowledge. In other words, not only a valid cognition is characterized by the fact that it apprehends the truth about its object, but it must also present a subjective state of total certainty about that.

Geshe Rabten makes a distinction between a true cognition and a valid cognition: "What characterizes a cognition to be true or false is whether the apprehension of its object is in accordance with reality or not, but not whether it is capable of inducing conviction and certainty about the object or not." (RABTEN, 1992, p. 54) Therefore, he continues, a true cognition is not necessarily a valid cognition. That means, a true perception, although it certainly corresponds to the

80 According to Dreyfus, this interpretation of Dharmakirti's epistemology, which he calls 'realist', was prevalent in Tibetan Buddhism as a whole until the fifteenth century. Therefore, he argues, it was not created by the Gelug school. Rather, the Gelug simply accepted the version of Dharmakīrti's epistemology which was already widespread among all Tibetan traditions of Buddhism. However, after the fifteenth century, the great Tibetan scholar Sapan's different interpretation of Dharmakīrti's epistemology, which defends that the universalgeneralities do not exist not even in the way explained by Dharmottara, opposed the Gelug view and became also a widely accepted theory, thus dividing Tibetan schools in two main different conceptions of epistemology and ontology as well. See DREYFUS, 1997 p. 193. 
truth about its object, may not be characterized by a mental state that fully apprehends this aspect of reality as truth, that is, as totally infallible and non-deceptive. On the other hand, he says, all valid cognitions are necessarily true cognitions also (RABTEN, 1992, p. 55). Besides, the Gelug manuals also distinguish between a correct assumption and a valid inferential cognition. A correct assumption is an assertion whose conception is in accordance with reality, that is, it is a true conception. Nevertheless, it is not yet a real comprehension, but merely an assertion. The difference between an assumption and a valid cognition refers to a distinction between mental states: the assumption, or assertion, is not a mental state of total certainty arrived at as a result of valid inferential reasoning. Instead, it is characterized exactly by the fact that it lacks a solid basis. Geshe Rabten says that it is "unable to give rise to any certainty and conviction about the fact" (RABTEN, 1992, p. 54). It may be true, but it is not infallible, or unerring, knowledge. And, since it does not have this characteristic of absolute certainty, it is not a valid cognition ${ }^{81}$. In order to clarify this, Geshe Rabten gives the example of an inattentive perception of a sound. It may be a perception of a true sound, but it is not a valid cognition "because the impression it leaves on the mind is not strong enough to induce any certainty as to what the sound was or whether one actually heard the sound or not." (RABTEN, 1992, p. 55).

Therefore, the validity of a cognition must comprise those two corresponding dimensions: it must include not only the non-deceptive ontological truth about its object, but also the nondeceptive, unerring subjective mental state of certainty, or total conviction, about this truth. Tsongkhapa says: "Those with little force of mind will determine this merely through an assumption, but those with strong mind should seek firm conviction induced by valid cognition. Otherwise, it will only be an assertion." (TSONGKHAPA, 1987, p. 87)

81 The Gelug manual provides definitions for these distinctions. A true assumption is "a fallible, conceptual mind that is consistent with reality in relation to the object of its belief'. There can be assumptions with a reason or without a reason. Khensur Rinpoche, in his explanation of the manual, compares the assumptions without a reason to a subjective state of 'blind faith', a mental state where a person holds something to be truth just due to the fact of having heard it from someone else, without having truly reflected upon it, without having searched for good reasons to support that speech. This type of mental state is 'fallible' because it can easily turn into a different opinion due to hearing other assumptions from different sources. On the other hand, the assumptions with a reason are considered as fallible because either they use contradictory reasons or indefinite reasons, or unestablished reasons, or reasons that are not based on proper foundations. (in KHENSUR Rinpoche, 2005, p. 236). 


\section{Conclusion}

At this point, we may raise one question regarding Tsongkhapa's use of Dharmakīti's epistemology in his presentation of the Madhyamaka philosophy. Since the Madhyamaka view denies not only the atomistic ontology present in Dharmakinti's writings, but also the very existence of natures (svabhāva, rang zhin) of phenomena, how can those two philosophical systems be united without generating internal contradictions? In other words, how can phenomena that do not possess any natures be conceived of as having 'one [same] nature', as explained above, so as to guarantee the validity of inferences? This is the main topic that have guided our analysis of Tsongkhapa's text 'The Great Exposition of the Stages of the Path (Byang chub lam rim che pa), Part Two; Insight'. 


\section{Part Three}

The Buddhist View of Selflessness

According to Je Tsongkhapa's Presentation in His

Great Exposition of the Stages of the Path to Awakening

(Byang chub lam rim che ba) 


\section{Chapter I}

\section{Introduction}

\section{The Import of the Oral Lineage}

As explained in the introduction to Part Two, in the Tibetan philosophical tradition, the philosophical schools keep their doctrines intact for centuries, passing them on along various generations from master to disciple through the commentaries and explanations of the classical texts. Specifically, the composition of treatises is accompanied by a lineage of oral explanation of the same text, usually believed to have been initiated by the author himself. As it should be the case with a genuine oral tradition, there are no additional ideas created by individual authors other than the ones who are considered as the founders of the school or the authors of the texts being taught. As the Gelug lineage spread its ideas and practices all over Tibet along its five centuries of existence, we nowadays find some differences in the way that the great monastic universities present some concepts. Those differences, however, usually refer to the interpretation of some specific subtle philosophical aspects of the general doctrine, but never to the general approach to an extremely important text, like the one that we shall present now.

Therefore, we consider the inclusion of the clarifications provided by Ven. Gonsar Tulku Rinpoche $^{82}$, an authentic 'holder of the oral Gelug lineage', as a necessary part of a research that

82 Gonsar Tulku Rinpoche is the abbot and main professor of the first Gelug monastery founded in the West, Rabten Choeling, located in Switzerland. It was founded to attend the Tibetan community of refugees that were received in Switzerland. As the monastery is located in Europe, it opened its courses to European and Westerners students in general along with the Tibetan refugee' community. For this reason, for all courses given in Tibetan, the monastery provides translations into English, French or German. 
intends to present the traditional Gelug philosophical view of selflessness with a high level of objectivity, avoiding thus as much as possible any personal subjective anachronic interpretations that could jeopardize the academic approach to the original text.

Gonsar Tulku Rinpoche's line by line explanations of Tsongkhapa's treatise have been audio recorded and are available at the monastery, what made it possible for us to use their content to approach the most difficult and dense parts of the text. He passed on the lineage of oral commentary to this text in a series of courses given along the period covering the years 2007-2012. The courses lasted 30 days each year, an average of 3 hours per day, adding up to a total of 450 hours. We have taken the audio recordings of those classes - a register of the transmission of the oral tradition - as a source for our research. Given the great amount of audio material accessed (line by line explanation) compared to the limited time for completing our project, we have been obliged to select the topics which we considered as the most crucial structural points of the text to present in our exposition.

The Translation

Gonsar Tulku Rinpoche's explanations were given in Tibetan with consecutive English translation provided by himself. He used both the original text in Tibetan as well as the English translation published by Snow Lion Publications (2002), so as to offer the possibility for students non-familiar with Classical Tibetan to follow the oral transmission. He also provided his own personal translation of some passages whenever he thought necessary. As our ability to read Classical Tibetan improved along this doctoral research, it became possible to follow the explanations using the original Tibetan text. Along our exposition, whenever we considered it suitable, we have chosen occasionally to use Gonsar Tulku Rinpoche's personal translation for quotations of the text, or else, in some cases, we have provided our own personal translation. 


\section{$\underline{\text { Registers of the Oral Lineage }}$}

We have also used as sources for our research the written register of the oral commentaries which are available in English:

1) Steps on the Path to Enlightenment - a commentary on Tsongkhapa's Lamrim Chenmo, vol 5 Insight, by Geshe Lhundub Sopa (with Dechen Rochard). It is the first - and so far also the only published written register of the complete transmission of the oral lineage of commentarial explanations to Tsongkhapa's "Insight" section of the great Lam-rim in English.

2) Four Interwoven Annotations to (Dzong-ka-ba's) 'Great Exposition...' (lam rim mchan bzhi sbrags $\mathrm{ma}$ ). This text is composed of the written register of four different Tibetan teachers' commentaries intertwined with the original treatise. It has evolved along the last centuries into its last version, which was printed in Delhi in the twentieth century. It has been partially translated into English by Elisabeth Napper.

\section{Priorities of our Presentation}

Tsongkhapa's work that is analyzed here is a long text, extremely rich in different types of arguments, quotations of authors considered as authoritative by him and references to other relevant aspects and practices of the Buddhist universe. Due to our limitation of time for the accomplishment of this project, we have been obliged, as mentioned before, to select the topics to be presented in our exposition as well as the lines of arguments used to defend the author's positions. We have thus decided to give priority to the explanation of those topics and arguments that deal with philosophical issues more closely related to the ones found in the European philosophical tradition. The first reason that moved us in such a direction is the fact that our own background, having studied Western philosophy for many years, naturally induced our approach to those issues which 
are more familiar to us and, therefore, easier to relate with. Another reason that is important to mention is our lack of familiarity with the vast complexity of the Buddhist conceptual universe, which actually comprehends a broad spectrum of practices other than the one that is directly related to the philosophical analysis - vipaśyanā (lhag mthong) - presented here. In order to provide indepth clarifications about the arguments that deal with those other practices, we would need much more time of study than the period available for an average doctoral research.

Nevertheless, we want to make it clear that such decision regarding the priorities of our presentation is not based anyway on conceptions according to which, the actual soteriological purpose of the Buddhist philosophical debates should be left aside from the academic approach to the Buddhist treatises, as some academics seem to consider. Differently, we do not think that taking into account the actual soteriological purpose of the author can hinder a purely scientific rendering of the philosophical content of such texts. Opposite to that, in our opinion, a truly scientific approach is the one that attempts to achieve an understanding of those treatises that corresponds as closely as possible to the intention of the authors. Indeed, the meaning of the Buddhist philosophical articulations cannot be legitimately separated from the original aim that moved the authors of such texts nor from the conceptual environment from where such debates emerged and where they certainly display their deepest sense. 


\section{Chapter II}

\section{Basic Prerequisite Notions $^{83}$}

"... one is unlikely to form a correct appreciation

of the works of the great Buddhist philosophers

unless one remembers that they were steeped

both in Buddhist literature and

in a tradition of meditative practice."

(GOMBRICH, R., 1991, p. 77)

83 The information gathered in the chapter 'Basic Prerequisite Notions' has three different sources: 1) Gonsar Tulku Rimpoche's teachings given from the 18th to the 22nd of May 2007, at Rabten Choeling; 2) Geshe Lhundub Sopa's commentary Steps on the Path to Enlightenment, Vol 1, chapter 6 - Refuting Misconceptions about Practice, Wisom Publication, 2004; 3) Pabongka, Rinpoche. Liberation in our Hands, Part Three, N. Jersey, USA, M.S.T. Press, 2001. 
The first thing to be clarified is the meaning of the Tibetan word which is translated as 'insight' in the English version, and which is used as the title of this entire part of the treatise. The Tibetan term 'lhag mthong' is a literal translation of the Sanskrit word 'vipaśyanä'. The TibetanEnglish Dictionary of Buddhist terminology ${ }^{84}$ defines 'lhag mthong' as "a single pointed concentration able to apply analysis on its object". Let us try to understand exactly what this means. 'Lhag mthong' is actually a combination of two separated terms which have their own independent meanings: 'lhag' is used by itself as meaning "exceeding, more, beyond, excellent, superior, surpassing, excelling"85; and 'mthong', in its turn, means "to look, to see, to view in the broad sense of the term as an ordinary faculty" ${ }^{\prime \prime 6}$. Therefore, a more literal translation of the word could be rendered as something like 'seeing beyond'. And 'seeing beyond' here means seeing beyond the ordinary way in which things appear to our daily perception of ourselves and the world around us. As we will explain further down, according to Tsongkhapa, this 'seeing beyond' is actually a type of meditation that involves both a very high level of concentration as well as a very precise philosophical analysis of the ultimate mode of existence of phenomena. However, before we start with the actual exposition of Tsongkhapa's text, a few preliminary considerations are needed in order to introduce the Tibetan meaning of some key terms.

The language that the Tibetans used to translate the vast Indian Buddhist literature was conceived in the second half of the $7^{\text {th }}$ century CE by a minister of the Tibetan king, who had spent a long period in India studying the Sanskrit language under the guidance of an important Brahman in Magadha. After returning to Tibet, he created the Tibetan alphabet and formulated grammar rules inspired in the Sanskrit language and in the task that lay ahead of him and of generations of other

84 Tibetan-English Dictionary of Buddhist terminology Tsepak Rigzin, Library of Tibetan works and archives, 1986, New Delhi, India.

85 A Tibetan-English Dictionary with Sanskrit Synonyms by Sarat Chandra Das, 1902, Calcuta, India.

86 A Tibetan-English Dictionary with Sanskrit Synonyms by Sarat Chandra Das, 1902, Calcuta, India. 
great Tibetan translators: to produce reliable Tibetan translations as close as possible to the original Sanskrit Buddhist texts. The first Tibetan translators and grammarians created Tibetan terms precisely equivalent to the Sanskrit terms of the Buddhist jargon, which made it possible for them to translate literally almost word by word. This is the reason why, although the Chinese translations were made earlier, the Tibetan ones are considered by the scholars as a better source for reconstructing lost Sanskrit originals. The Chinese translations, although they may be very good, they are just like ours, that is, they also try to render this very peculiar and unique jargon in a preexisting language, struggling most of the time to find satisfactory suitable terms.

The word 'Ihag mthong' is a good example of the Tibetan efforts. As mentioned before, it translates 'vipaśyanā', where 'lhag' corresponds to 'vi', and 'mthong' to 'paśyanā'. Although we shall use the English translation 'insight' from now on, we consider it necessary to bear in mind that the word 'insight' in the present context has this very specific and precise meaning: seeing beyond the ordinary appearances. According to Tsongkhapa's approach to Buddhist practice and philosophy, such 'seeing beyond' the ordinary appearances is not a mystical experience attained by chance nor grace. Rather, it is the result of rigorous philosophical rational analysis applied to our common perception of phenomena united with a highly developed power of concentration.

Vipaśyana, or lhag mthong, is actually a specific type of meditation. It is a meditation which has the purpose of generating wisdom (shes rab, prajñ $\bar{a}$ ) in the mind of the practitioner. The word commonly translated into English as 'wisdom' also requires some explanation. Its root - shes, jũa refers to an event of perception or knowledge, that is, it refers to a mental event that perceives (or 'is conscious of') a certain object and is able to know, or to identify, what it is. This term is used to identify the different types of sense perception, so that, for example, a visual perception occurring in dependence on the eye is named "mig gi nam shes" and is translated as 'eye consciousness'; the perception of sound is called "nab'i nam shes", translated as 'ear consciousness', and so on, covering the five sense perceptions. "Shes" is sometimes also translated as 'to perceive' or 'to know', or 'to be aware of', 'to be conscious of'. The first term derived from this root, which is "shes-pa" can be translated as 'awareness', 'consciousness' or 'knowledge'.

On the other hand, the word ' $r a b$ ', which is the second part of the Tibetan term 'shes $r a b$ ', and corresponds to the Sanskrit 'pra', means 'best, higher, superior, excellent, pure' ${ }^{187}$. Here again, this etymological elucidation has the purpose of helping us to bear in mind the precise meaning of 'shes $r a b$ ', which is, 'higher knowledge', 'higher perception' or 'excellent knowledge', 'excellent 87 A Tibetan-English Dictionary with Sanskrit Synonyms by Sarat Chandra Das, 1902, Calcuta, India. 
perception', or still, 'excellent awareness'. The term 'higher' or 'excellent' refers to the fact that this knowledge is supposed to be faultless, it is supposed to be excellent, or perfect, in a way that it ascertains the mode of being of its object. It is sometimes also translated as 'discriminative awareness $^{188}$, or even, as 'intelligence', so as to convey its distinctive characteristic of being able to discriminate perfectly its object. Keeping in mind its meaning in the context of Buddhist philosophy, we can continue to use its most common English translation: wisdom.

Buddhist philosophy considers that there are three types of wisdom (shes rab). The first one is the wisdom derived from hearing (thos-byung gi shes rab, srutamayiprajñ $\bar{a}$,). This is the type of knowledge which is generated in a practitioner's mind when he or she listens to clear explanations about reality and is able to understand the meaning of what is explained. This is actually considered the first level of wisdom, that is, the first step towards generating genuine wisdom in oneself. However, it is not considered yet proper knowledge in the epistemological sense of the term 'knowledge'. Knowledge in its epistemological sense is, as defined by Dharmakīrti, 'valid cognition' (tshad ma, pramāna), a concept which was briefly explored in Part Two.

The wisdom of hearing is not considered 'valid cognition' because, as mentioned in the previous part, there are only two types of 'valid cognition': 1) valid perceptual cognitions, like, for example, the correct cognition of this desk in front of me as a desk; and 2) valid inferential cognitions, which are produced by means of inferences (rjes su dpag pa, anumāna), as explained previously. The wisdom of hearing is clearly not of the first type, as it has to do with concepts and reasonings. But why is it not considered 'valid cognition', since it has as its object the concepts, reasonings and inferences of the speaker, which are heard and, supposedly, correctly understood?

As explained at the very end of last chapter, the concept of 'valid cognition' comprehends not only the ontological truth regarding the object cognized, but also a subjective state of total certainty about this truth. This subjective mental state, which is called 'ascertainment', must be the result of a process or reasoning in one's own mind. The fact that the practitioner has heard and understood at some level those inferences taught by another person does not mean that he or she has also gone through the whole mental process that constitutes the proper formulation of the inferences, having thus reached, or produced in his or her own mind, the correct conclusion, which is then, and only then, considered as 'valid cognition' in the correct sense of the term. In other words, for a cognition produced by an inference to be considered as 'valid' knowledge in the mind of someone, the whole process of the inference, step by step, must be accomplished by this person,

88 Tibetan-English Dictionary of Buddhist terminology Tsepak Rigzin, Library of Tibetan works and archives, 1986 , New Delhi, India. 
so that the conclusion arrived at appears to oneself as totally solid and unshakable. Clearly, this mental exercise cannot be done while listening to the speech of another person.

This 'mental exercise' is called 'contemplation' (bsam byung;cinta;) and is characterized by the mental application of one's full attention to a given chain of reasoning, or specific topics, leading to a conclusion. It is usually performed several times repeatedly before the conclusion arrived at reaches a state which is considered 'solid' enough to be called proper knowledge, or 'valid cognition' (tsad ma; pramāna). Before this is accomplished, even though a person may generate the so-called 'wisdom of hearing' regarding some topics which are considered definitely true in Buddhist philosophy, like the selflessness of phenomena, this 'wisdom of hearing' is not considered yet as 'knowledge', but only as correct belief or correct assumption. This is the reason why, after having explained the arguments proving the non-existence of a personal self separated from the aggregates, Tsongkhapa says:

You should repeatedly practice so as to reach solid certainty that arguments such as
these contradict the existence of a self that is essentially different from the
aggregates. For, if you do not develop genuine certainty about the critique of the
positions of one and different, then even though you may decide that the person
lacks intrinsic existence, it will be just an unproved proposition; hence, you will
not obtain the authentic view. (TSONGKHAPA's Lam Rim Chen Mo, Vol 3, 2002,
p. 297)

The second type of wisdom is the one that is generated through contemplation and is called 'wisdom of contemplation' (bsam byung gi shes rab, cintayiprajĩāa). This wisdom, as just explained, is already considered as real 'knowledge'. The third type is the wisdom produced through meditation (bsgom byung gi shes rab, bhāvanāmayiprajñā).

It is important to clarify also the meaning of the word 'meditation' for this tradition in order to explain how it relates to the philosophical presentation of reality. The Tibetan word which is translated into English as 'meditation' (sgom) $)^{89}$ originally meant 'to fancy' or 'to imagine'. After the full introduction of Buddhist practices in the Tibetan culture, a new meaning was added to that one: 'to contemplate systematically' or 'to reproduce in one's mind'. Two basic types of meditation are used in combination by the Gelug followers. They are: analytic meditation (dpyad sgom) and placement meditation ('jog sgom). In the 'analytic meditation', the practitioner is supposed to analyze, or examine, several times the object of meditation. The term 'analysis' (dpyad), or examination, refers to a mental exercise in which the mind examines the object of concentration, 
including all its parts, or aspects, focusing on one by one repeatedly. If the object of concentration is an image of a physical entity, for example, a mental image of the representation of Buddha Shakyamuni, the mind should engage its attention in the image's different parts one by one several times, starting, for instance, focusing on the legs. After examining carefully and in details all aspects of the legs, like its color, the feet, the knees, the way they are positioned etc., the mind then focuses on the upper parts of the body - the trunk, the arms and hands, the face etc - one by one.

The object of concentration may also be a discursive one, that is, some subject of the teachings of the Buddha, like for example, the truth of suffering or the selflessness of phenomena. In that case, the analytical meditation proceeds by examining one by one all the aspects or topics of that teaching. Regarding the teaching about the selflessness of phenomena, the practitioner should repeat in his or her mind all the arguments, demonstrations and clarifications provided by the teacher. This repetition must follow a specific order, the same order in which the explanations were transmitted. Through repeatedly examining, or analyzing, the arguments with full attention, the practitioner is able then to clarify all his doubts, and finally reach a conclusion which is solid and stable. This conclusion, however, must not be a mere superficial repetition of what was taught. Rather, the practitioner must truly examine and analyze the arguments and explanation in a most honest way, letting all possible doubts be raised and honestly dealt with.

When analytical meditation is applied to conceptual objects, like the explanation of selflessness, for example, it is deeply connected to two types of mental activities which are sometimes translated as 'deliberation' (rtog pa, vitarkah) and 'reflection' (dpyod pa, vicarah). Deliberation (rtog pa, vitarkah) is defined as a mental activity which examines its object of concentration asking 'What is this?' Reflection (dpyod pa, vicarah), in its turn, is defined as 'an analysis that determines that the nature of this object is such and such'.

The second type of meditation, the so-called 'placement meditation', or 'fixed meditation' ( jog sgom), has a totally different kind of purpose. Its objective is to develop the capacity of the mind to concentrate on one single object steadily as long as possible. The mental state which is achieved through this kind of training is called 'śamatha' in Sanskrit and 'zhi gnas' in Tibetan. This term has received different translations in English: calm abiding, tranquil abiding, meditative serenity, quiesence etc. The Tibetan word is a combination of two terms: ' $z h i$ - $b a$ ', which means 'to be peaceful or calm', 'to become pacified, still, quiet, dispassionate', 'not subject to any mental emotions', and the verb 'gnas', which means 'to live', 'to stay', 'to continue' or 'to abide'. Therefore, the literal meaning is 'to abide pacified'.

This state of pacification refers to a calmness or stillness of the mind. As a result of a 
specific training, the mind has the ability to develop fully its capacity to remain fixed one-pointedly on a single object. All the details about how to proceed in order to undergo such a training are carefully described by Tsongkhapa in the long part of this treatise that comes just before the presentation of the philosophical view of reality, which is the subject-matter of our analysis. This training, which lasts a minimum of six months of full time meditation, with breaks only for meals and sleep, is supposed to lead the mind step by step from its ordinary state, where it possesses a very low capacity of concentration of just some minutes, to a state of full control, when the mind becomes able to remain totally focused on its chosen object of attention without moving away from it at all. This means that, apart from the present active perception, or apprehension, of that chosen mental object, there are no other movements occurring in the mind, no thoughts, no ideas, anything. That is why it is described as a 'non-discursive' mental state.

Non-discursiveness is the first of the three characteristics that Tsongkhapa mentions as the features that define śamatha (zhi gnas). The other two are clarity and benefit. The word 'clarity' refers to the fact that this mental state should also be free from any kind of sinking, or laxity. This means that the full capacity of concentration alone does not yet define śamatha, because there are states of full concentration which, despite holding their objects of attention with no other mental movements, are still subject to this other obstacle: laxity. In this case, the object is not apprehended with full clarity and brightness, due to the fact that the mind's focus is still too relaxed, which makes the appearance of the object still unclear. The third characteristic that defines śamatha, benefit, refers to the very intense sensation of bliss that should accompany this high state of mental concentration. It is described as a physical and mental experience of ecstasy.

The attainment of the real state of śamatha is indicated by the presence of those three features altogether. If one of those three characteristics is missing, this means that śamatha has not been achieved yet ${ }^{90}$. Tsongkhapa dedicates a long part of his treatise to the presentation of a very detailed description of the mental training leading to this high level of concentration as well as of the expected result of such a training, that is, of all the signs that accompany the attainment of śamatha. This is done with the intention of assuring that his instructions will not lead his readers or followers to any other mental states which do not correspond precisely to the real accomplishment of 'pacified abiding', exactly as this is described and taught in the classical texts of the Indian Buddhist tradition, starting with the Prajñāpāramitā Sūtras, Asañga's Bodhisattva levels, Asanga's

90 For a complete description of the whole process of nine stages that lead to the state of śamatha, refer to Tsongkhapa's Great Treatise on the Stages of the Path to Enlightenment (Byang chub lam rim che pa), vol 3, Snow Lion Ed., Ithaca, New York, 2000-2003; and to 'Pabongka, Rinpoche. Liberation in our Hands, N. Jersey, USA, M.S.T. Press, 2001; days 21 and 22. 
Sravaka Levels and other classical works that teach how to develop perfect concentration ${ }^{91}$. Tsongkhapa urges his followers to seek the guidelines contained in those Indian classical masterpieces, warning them that those who do not do so risk to miss the real path taught by Buddha Shakyamuni: "Profound are the descriptions of the stages for achieving concentration well taught in the sütras and the great commentaries. (...) There is nothing apart from the meaning of the instructions in the treatises..." (TSONGKHAPA's Lam Rim Chen Mo, Vol 3, 2002, pp. 102-103)

91 For a list of those texts, refer to Tsongkhapa's Great Treatise on the Stages of the Path to Enlightenment, vol 3, Snow Lion Ed., Ithaca, New York, 2000-2003, p. 101. 


\section{Chapter III}

\section{Why It is Necessary to Practice Vipaśyanā}

The same approach as the one described above regarding the practice of śamatha is found in Tsongkhapa's presentation of the practice of Insight (lhag mthong, vipaśyanā) as well. That means, according to him, his explanations of selflessness are entirely based on the commentaries composed by Nāgārjuna, Buddhapālita and Candrakīrti, as mentioned previously.

The practice of Insight (lhag mthong, vipaśyanā) sustained by the perfect concentration of Pacified Abiding (zhi gnas, śamatha) is found only in the Buddhist tradition. The analytical meditation that establishes the selflessness of phenomena after an exhaustive and comprehensive process of rational examination, which is what the practice of vipaśyana consists of, was added by Buddha Shakyamuni to the practice of śamatha that he had learned with the two teachers he had before he decided to pursue his meditation all by himself. Therefore, this same method to attain perfect concentration can also be found in other yogic traditions. In those traditions, however, it is considered as THE method to totally eradicate the root of suffering. Buddha Shakyamuni, on the other hand, after having attained all the highest meditation absorptions taught to him by his teachers, concluded that this path did not actually lead to destruction of the deepest cause from which our suffering originates. According to him, the only result that the development of concentration can have in this respect is to prevent the causes of our suffering, which are attachment and aversion, to manifest in the mind, for the mind finds itself totally absorbed on its object of concentration, thus leaving no possibility for any other mental factors to arise. Attachment and aversion are subdued by the power of concentration, but potentially, they are still there. Their root 
has not been truly eradicated.

According to Buddhism, there is a deeper cause that is actually the seed from which those 'fruits' (bras bu) - attachment and aversion - are generated. This deepest seed is called ' $m a$-rig- $p a^{\prime}$ in Tibetan (Sanskrit: avidya), which means lack of knowledge, or lack of awareness ${ }^{92}$. It refers to the 'lack of knowledge' about reality (dekhonanyid, tattva), that is, 'lack of awareness' of the ultimate mode of existence of oneself and all other phenomena. The philosophical expression used by the Gelug that corresponds to the notion of 'ma-rig-pa' is 'incorrect view of reality', and it is explained as the projection of an illusory self onto phenomena that actually lack it. And here Tsongkhapa quotes Kamalaśíla to support his point: "Although worldly persons cultivate concentration, they do not destroy the notion of a self; afflictions return and disturb them..." (TSONGKHAPA, 2002, p. 107)

Among Buddhists, 'ma-rig-pa', or the incorrect view of reality that projects a self onto phenomena, is considered the very root from which our suffering arises. And just like it happens to a plant that is cut only in its surface, in which case there is always a possibility that it may grow again from the root that was left untouched inside the earth ${ }^{93}$, if this mistaken notion of a self, and the consequent grasping to this self, is not eliminated from the mind, although a very high level of concentration may pacify attachment, aversion and the sufferings for a while, once this concentration is interrupted, those mental states can easily manifest again in the presence of certain conditions. Therefore, in order to liberate oneself definitely from all types of suffering, it is necessary to eradicate, once and for ever, this very fundamental misconception of reality. Tsongkhapa comments:

...through analyzing individually the lack of a self in phenomena, you generate the wisdom (shes rab) that understands the meaning of selflessness (...); then one meditates through sustaining that view (...). This is the cause of the result which is the attainment the nirvana. (TSONGKHAPA, Byang chub lam rim che pa, p. 565, oral translation by Gonsar Rimpoche, $19^{\text {th }}$ of May, 2007, Rabten Choeling.)

The procedure should follow precisely the steps mentioned above, that is, first the practitioners are supposed to apply the rational analysis to a given phenomenon so as to attain a definite conclusion in their minds, according to which that phenomenon is actually deprived of a

92 The word 'rig-pa' (Sanskrit: vidyā) means 'knowledge', 'awareness' or 'science'. The prefix 'ma' in Tibetan, as the prefix 'a' in Sanskrit, is a negative particle, thus rendering the translation of 'ma-rig-pa' as 'lack of knowledge' or 'lack of awareness'.

93 Verbal information by Gonsar Rinpoche, 19th of May 2007, Rabten Choeling. Transcribed from audio recordings of the commentarial explanation about this treatise. 
self, despite the fact that their ordinary cognition has always projected such a self on it. After the conclusion has been reached and thus the view of the selflessness of that phenomenon has arisen very clearly in their minds, the practitioners should then apply the śamatha concentration on it, sustaining then this view for a long time. The more this view of selflessness is maintained in the mind, the stronger is its effect as an antidote to the mistaken view that sees phenomena as possessing their own intrinsic selves. The procedure should be repeated as many times as possible until the mistaken view is eventually completely eliminated. That is how the wisdom of meditation is generated. In the Four Interwoven Annotations, it is said: “... if you analyze the reasons for [selflessness] again and again, your ascertainment becomes stronger and stronger, whereby the conception of self is badly damaged." (in NAPPER, 2003, p. 237)

The focal point of this type of meditation, though, is not supposed to be the selflessness of any outer objects. Rather, the crucial object of this meditation is the selflessness of one's own person, that means, the object that is construed by the mind when one uses the concept 'I', as opposed to everything else which is not included in this 'I'. The process of analysis may start with another object of conception, like the chariot for instance, which is the classical example of analysis of selflessness used in many Buddhist texts, including in Tsongkhapa's treatise. However, this is just a preliminary stage. This preliminary stage is considered necessary because it is much easier for our untrained mind to capture, in the flow of our mental stream, the construed 'self' of an outer object, like the chariot, in order to analyze it and then realize that such an identity - the chariot - is simply a construction of our own cognition and thus does not exist in the object itself. The conception of one's own 'I', on the other hand, is much subtler, and therefore much more difficult to grasp. Nevertheless, the crucial vipaśyanā, the one that can really bring about the expected result of eradicating totally the mental afflictions - that is, attachment, aversion and all the secondary afflictions originated from those two, like, greed, hatred, fear etc - is the analysis applied to our mistaken view of our own person.

This type of meditation has a specific name: 'non-interruption path' (bar chad med lam, $\bar{a}$ antaryamārgh). It is the ultimate meditation that brings about the definite cessation of our mental habit of projecting an inherent self onto phenomena in general and specially on our own persons. When this permanent cessation is achieved, this practitioner is said to have entered the state of nirvana, where there is no more experience of any kind of suffering. This is obtained, of course, as a result of a long and very stable dedication to the practice, going through all the various stages that lead to this final expected result. 
However, it is necessary to clarify that, according to this system, there are two distinct types of 'mistaken view of reality': The innate one (ngar dzin lhan brtags, sahajatmagrahah) and the conceptual one (ngar dzin kun skyes, parikalpitatmagrahah). The conceptual mistaken view of reality is the one that is acquired through the adoption of mistaken philosophical ideas based on wrong reasonings. The innate mistaken view, in its turn, is unconscious. It is the spontaneous habit that we have to project inherently existing selves when we ordinarily cognize phenomena. It is the spontaneous tendency to see reality as composed of intrinsically existing selves which arises in us without any philosophical ideas nor reasonings. The conceptual mistaken view is much more superficial and, therefore, can be eliminated much more easily. It is not necessary to use deep meditation to destroy superficial conceptions or philosophical ideas acquired through mistaken reasonings. The unconscious spontaneous innate mistaken view, on the other hand, is not easy to uproot. That is why meditation is needed in this case.

First of all, it is necessary to recognize in our own ordinary process of perception how our cognition spontaneously apprehend phenomena as having their intrinsic selves. This mere neutral observation of our own mental acts when we ordinarily cognize phenomena already requires a very high level of concentration. And more than anything else, here it is at stake, as explained above, the mental act of cognizing, or apprehending, the phenomenon of our own existence as a person, or self, to which the label "I" is then imputed. All this happens at a very subtle level of the mind and its functioning as a cognizer. Therefore, deep introspection is supposed to be exercised, along with a sophisticated philosophical analysis of the real mode of existence of this "I" as well as of all phenomena generally speaking.

But if the establishment of the philosophical correct view of reality, that is, the selflessness of the "I", is the hallmark that distinguishes the Buddhist practice from the other important yogic communities of Ancient India, why does Tsongkhapa consider it necessary to quote here greatly revered masters of the past in order to support his claim that it is absolutely indispensable to carry on the practice beyond the attainment of śamatha (pacified abiding) into the practice of vipaśyanā (extraordinary seeing)? And Tsongkhapa himself gives us the answer for that question when he says that one important composition of Kamalaśîla ${ }^{94}$ quotes a verse of the sütra "King of concentration", asserting that "there is no peace through any other means" but through the cultivation of vipaśyanā in meditation, and that Kamalaśíla's quotation has a very specific purpose, which is "to discredit the assertions of the Chinese abbot Ha-Shang". (TSONGKHAPA, 2002, p. 108)

94 "Stages of Meditation". 
In order to understand the meaning of this passage, we need to go back a few centuries in the history of Buddhism in Tibet. One important event explains why Kamalaśíla needed to discredit the Chinese abbot Ha-Shang. It is the so-called "Great Debate" at Samye ${ }^{95}$. At the very beginning of the introduction of Buddhism in Tibet, there were not only important Indian Buddhist teachers, like Kamalaśîla, who dedicated their best efforts to the propagation of the teachings of Buddha Shakyamuni in that country, but also some great Chinese Buddhist monks endeavored seriously to take their lineage of practice to their neighbor land. However, the approach that the Chinese monks had to the Buddhist practice was quite different from the one which was taught by the Indian meditators. Since the points of divergence were very crucial, really touching the core of the Buddhist doctrine as a whole, it was decided that a debate should be organized between the greatest representatives of those two different interpretations, and that the winner would then be granted the responsibility of establishing Buddhism in Tibet.

Historical sources assert that around the year 792, king Khri-srong of Tibet presided personally the debate between Chinese and Indian Buddhist teachers. It lasted not less than two entire years ${ }^{96}$. The Indian teachers, in accordance with the way that Buddhism was practiced in India, defended the idea that the practice towards awakening must follow specific gradual stages in their right order. In other words, it is necessary to go through a step by step development and deepening of the abilities of the mind until it reaches its full capacities, and the practice of philosophical analysis - vipaśyana - is definitely indispensable. The Chinese monks, on the other hand, were proponents of the so-called 'concentration' school ${ }^{97}$, which is considered by the Gelug as 'spontanist', that is, a view according to which there is no need to go through a gradual process of development. All that one has to do is to meditate developing concentration, and this alone will lead to a sudden attainment of the supreme state of the awakened mind (Buddha) ${ }^{98}$. The followers of the Gelug school consider that the Chinese abbot Ha-Shang propagated a sort of 'no-thinking'

95 First Buddhist monastery founded in Lhasa.

96 Per Kvaerne, 'Tibet: the rise and fall of a monastic tradition' in The world of Buddhism, Tames and Hudson, 1984, London

97 'Ch'an' in Chinese, 'Zen' in Japanese. The Chinese name of this school - Ch'an -, wich later was pronounced as 'Zen' in Japan, is said to have its origin in the way that the Chinese pronounced the Sanskrit word dhyanna, which means 'concentration'. (Hershock, Peter, "Chan Buddhism", The Stanford Encyclopedia of Philosophy (Spring 2017 Edition), Edward N. Zalta (ed.), URL $=<$ https://plato.stanford.edu/archives/spr2017/entries/buddhism-chan/>.)

98 The discussion about whether or not this is truly the way that the Chinese Ch'an proponents approached the Buddhist teachings is beyond the scope of this thesis. There are no doubts, however, about the fact that this is the way in which Tsongkhapa understands the historical debate between the Indian Buddhist teachers and the Chinese abbot Ha-Shang. Moreover, according to Kvaerne, in philosophical debates between Tibetan Buddhist schools in general, "the accusation of propagating 'spontanist' views was considered to be most serious." (KVAERNE, 1984, p. 253) 
meditation, that is, a type of meditation in which the practitioner is supposed to stop, or suspend, all mental activities. Any kind of thinking, refection or analysis of mental objects is considered as a hindrance to be avoided and finally totally overcome ${ }^{99}$. Clearly, this kind of approach is opposite to the type of Buddhist practice that the Indian teachers defended, since there is no place for the full dedication to the philosophical analysis required to establish the correct view of reality.

The famous "Great Debate" at Samye was won by the Indian pundits. They received full support from the king to establish their teachings in the land of snow, while the Chinese 'Ch'an' proponents eventually had to leave the country. However, despite the fact that the Buddhism that flourished in Tibet from then on was the one that propounded a gradual path in which the practice of the philosophical analysis is absolutely crucial, Tsongkhapa still considers it necessary to open his section on vipaśyanā reminding his readers of the absolute necessity of such a practice. And he quotes Kamalaśīla to support his point:

\footnotetext{
"One who is satisfied with mere concentration (...) might develop an inflated sense of pride, [mistaking] mere concentration for the path of meditation on the profound meaning." (TSONGKHAPA, 2002, p. 108)

“...by hearing from others, one will be liberated..." (TSONGKHAPA, Byang chub lam rim che pa, p. 566) ${ }^{100}$
}

'Hearing from others' here refers to the first level of wisdom explained above: the wisdom of hearing. The Buddha was the first one to attain the very subtle, or very profound, view of selflessness that goes beyond mere concentration. He then explained to his followers how to achieve the same realization, and through listening to the clarification given by Buddha Shakyamuni, they were also able to generate this level of understanding. Then, through contemplating and meditating on the same clarification, they finally achieved the same view of selflessness as the Buddha himself had done. The fact that the practice should start with the wisdom generated from hearing the explanation from someone who has attained the wisdom of meditation is called 'transmission from master to disciple' and is considered, by most Buddhist traditions, an indispensable condition for a genuine practice.

And again this serves the cause of opposing the view defended by the 'concentration school'

99 Verbal information by Gonsar Rinpoche, 19th of May 2007, Rabten Choeling. Transcribed from audio recordings of the commentarial explanation about this treatise. 
(Ch'an), as it stresses the fact that the ultimate view of reality will not just simple reveal itself to the meditator due to his efforts to develop the capacity of focusing the mind unshakably on one mental object. No matter how long he or she may wait for this revelation while maintaining a very high level of focus on one object, reality (dekhona, tattva), the ultimate mode of existence, will not spontaneously appear to his or her perception ${ }^{101}$. In this sense, Tsongkhapa affirms: " 'Pacified abiding' (zhi gnas, śamatha), that is, one-pointedness of mind, does not become pure perfect wisdom”. (TSONGKHAPA, Byang chub lam rim che pa, p. 566) ${ }^{102}$.

The last argument used by Tsongkhapa to conclude this topic is on important reminder. He reminds us that the Buddha taught that for the attainment of full awakening to reality, the Bodhisattvas must practice the six perfections, or six päramitās (pha rol tu phyin pa) ${ }^{103}$. Among the six perfections, the two last ones are the perfection of concentration, which corresponds to śamatha, and the perfection of wisdom (Prajñāpāramitāa), which corresponds to vipaśyanā. Therefore, if the Buddha separated those two practices into two different pāramitās, there are no doubts whatsoever that concentration alone can not lead a practitioner to the view of ultimate reality. Boddhisattvas must add vipaśyanā to their perfect concentration. Tsongkhapa thus concludes: "Among all the perfections, the perfection of wisdom is the one that investigates reality". (TSONGKHAPA, Byang chub lam rim che pa, p. $567^{104}$ ). And he quotes Kamalaśîla again: "Therefore, dwelling in 'pacified abiding' (zhi gnas, śamatha) [and using] wisdom (lhag mthong, vipaśyanā), I will accurately seek reality." (TSONGKHAPA, Byang chub lam rim che pa, p. $\left.567^{105}\right)^{106}$.

101 Verbal information by Gonsar Rinpoche, 19th of May 2007, Rabten Choeling. Transcribed from audio recordings of the commentarial explanation about this treatise.

102 Our translation.

103 Donald S. Lopez, in The Heart Sutra Explained: Indian and Tibetan Commentaries, explains the different interpretations of the Sanskrit term 'pāramitā'. According to him, it has two diverse etymologies: "The first derives it from the word parama, meaning "highest", "most distant", and hence "chief", "primary", "most excellent". Hence, the substantive can be rendered "excellence" or "perfection". This reading is supported by the Madhyāntavibhāga (V.4), where the twelve excellences (parama) are associated with the ten perfections (pāramitā). A more creative yet widely reported etymology divides pāramitā into pāra and mita, with pāra meaning "beyond", "the further bank, shore or boundary," and mita, meaning "that which has arrived," or ita meaning "that which goes." Pāramitā, then means "that which has gone beyond," "that which goes beyond," or "transcendent." This reading is reflected in the Tibetan translation pha rol tu phyin pa ("gone to the other side") and is supported by such renowned figures as Asanga, Vasubandhu and Candrakirti, as well as the Heart Sutra comentators Jnanamitra, Prasastrasena and Vajrapani. (...) Candrakirti, in the first chapter of his Madhyamakavatara, defines the 'beyond' as the shore or port of the ocean of samsara and identifies it with Budhahood..." (LOPEZ, 1988, p. 21-22)

104 Our translation.

105 Our translation.

$106 \mathrm{We}$ should remind ourselves here that the word translated a 'wisdom' (shes rab, prajñā) has also the meaning of 'intelligence', or even of 'discriminative awareness', in the sense of analysis or discernment that investigates the nature or essence of phenomena. So, wisdom here is something to be practiced, it is a mental activity that is supposed to reveal the truth about phenomena. 
Considering that it is now clear that it is indispensable for a Buddhist practitioner to strive in the practice of vipaśyana, Tsongkhapa moves on to the next point of his presentation, which discusses the actual steps that must be taken in order to be able to engage in such a practice. The first step is "relying upon the collection for vipaśyana". The Tibetan word 'tshogs' (pronounced 'tsog'), which means 'collection', refers here to the set of causes and conditions that must be gathered as a prerequisite. Why is there a prerequisite? As explained in Part Two, Buddhist ontology is based on the fundamental notion that all phenomena are 'dependent-arisings' (rten byung, pratītyasamutpāda), that is, every existent thing arises in dependence upon certain causes and conditions. This is valid also for all human activities or endeavors. Therefore, the practice of vipaśyanā also requires specific causes and conditions in order to be developed. The word translated here as 'relying' literally means 'depending'. Hence Tsongkhapa is saying that we must 'depend' on certain causes and conditions in order to be able to generate in our minds the proper practice of vipaśyana $\bar{a}^{107}$.

And, according to him, we must depend, or rely, upon a scholar who understands perfectly the teachings about emptiness. He says that we must 'listen' to the treatises, referring here to the oral lineage of commentaries: "You should listen to the stainless textual systems, relying on a scholar who accurately understands the key points of the scriptures." (TSONGKHAPA, 2002, p. 111) That means, we must listen to the explanations of the oral lineage of commentaries of the treatises given by a teacher that has truly gained the perfect understanding of all the subtle and essential points, and preferably, has also developed in his or her own mental continuum the united practices of 'pacified abiding' and 'superior seeing'. Only those conditions can provide a very high level of accuracy in the way that such special instructions are transmitted.

Tsongkhapa takes as texts to be relied upon not only the discourses of the Buddha about emptiness, like the Prajñāpāramitā Sütras, but also those explanatory commentaries of such discourses which, according to him, do actually disclose perfectly, and with the highest level of accuracy, their real meaning. Those are the commentaries composed by Nāgārjuna, first of all, and secondly, those composed by Buddhapālita and Candrakīrti, which comment on Nāgārjuna's treatises.

107 Verbal information by Gonsar Rinpoche, 20th of May 2007, Rabten Choeling. Transcribed from audio recordings of the commentarial explanation about this treatise. 


\section{Chapter IV}

\section{How to Establish the View of Emptiness}

\section{The Stages of Entering into Reality}

The attainment of the correct view, also called by Tsongkhapa as 'entering ('jug pa)' into reality', is accomplished in stages. First of all, one needs to know what is this reality that one is searching for. Tsongkhapa defines it as "the total extinction of conceptions of both the self and that which belongs to the self, specifically by stopping all the various internal and external phenomena from appearing as though they were reality itself..."(TSONGKHAPA, 2002, p. 119). And he provides here a short summary of the main stages one is supposed to go through before even starting to seek this reality. First it is necessary to generate an unshakeable determination to overcome one's present condition of being constantly subject to all types of suffering. Secondly, one should investigate deeply, also in meditative introspection, which is the cause of this condition in one's own mind ${ }^{108}$. If the methods taught by the Buddha for practicing such introspective

108 It is important to remind ourselves here that the practice of 'Insight ' which we are studying in this part of the treatise is actually an advanced stage of the Buddhist meditation, being thus preceded by many prerequesites which, due to the limitations of space and time, we cannot present in the scope of this thesis. The in-depth explanation of the three types of suffering, the methods for recognizing them in introspection and the way to recognize which is the deepest cause of such sufferings are found in the previous parts of Tsongkhapa's Great Exposition of the stages of the path. Those are the explanations of the first two of the famous Four Truths taught by the Buddha, that is, the Truth of Suffering and the Truth of the Cause [of suffering]. 
investigations are applied correctly by the practitioner, he or she supposedly reaches the experience that realizes that all the sufferings originate from the 'view of the perishing collection' ('jig tshogs la lta ba, satkāyadrstí).

The expression 'perishing collection' refers to the main 'parts' which compose a human being according to the Buddha. These 'parts' are called 'piles' (phung po, skandhas), usually translated into English as 'aggregates'. They are five:

1) form (gzugs, rüpa) > the various material forms that make up the body;

2) feelings (tshor $b a$, vedana $)>$ refers specifically to the feelings of pleasure, pain or neutral feeling;

3) perceptions ('du shes, samjña $)>$ the data provided by the five physical senses:

4) formations (or 'volitions') ('du byed, samskkāra) > refers to all mental and physical factors that make up our actions, from the volition, in the sense of the decision of performing a given act, up to the physical performance of the act itself.

5) cognitions (or consciousnesses) (rnam shes, vijñāna) $>$ refers to the identification of data as specific things, like for instance, 'this is a chair'.

They are called 'perishing collection' because they are impermanent, that is, changing moment after moment, thus perishing moment after moment. However, the so-called 'view of the perishing collection' which is the deepest cause of the sufferings, is a mistaken view of the collection, that is, instead of seeing its impermanence and emptiness of a self, it conceives the opposite of that. This view mistakenly conceives the collection of the aggregates as a permanent 'I'. It also mistakenly conceives the aggregates as objects possessed by this 'I', so that this 'I' has its own body, its own feelings etc, that is, it has a body that belongs to it, feelings that belong to it etc. It is known as the mistaken conception of the 'I' and 'mine'.

Tsongkhapa is certainly not referring here to a philosophical articulation, although there have also been philosophical articulations of such a belief in a permanent 'I', or individual soul, along the history of mankind, not only in India, but in the West as well. But that is not what is at stake in Buddhism. As mentioned before, the false conception that should be dissolved by the practice of vipaśyanā is not a view acquired as a result of intellectual elaborations. Instead, it is an innate tendency, a very subtle conception that all human beings have spontaneously, and which can be discovered in one's mind only through deep introspection. As G. Sopa says, “...to our natural way of thinking, our 'I' seems to be a unit, something single, with its own identity." (SOPA, 2017, 
Once this second stage has been accomplished, that means, the practitioner has been able to recognize that the cause of the sufferings is this conception of a 'self' ('I') and that, due to that, this false conception must be eradicated from one's mind, the next step, according to Tsongkhapa, should be the search for the most precise realization of how this mistaken 'self' is being conceived. He quotes Candrakīti to support his point: "Hence, at the very beginning they [the meditators] examine only the self, asking, 'What is the self that is the object of the conception of a self?" ( TSONGKHAPA, 2002, p. 121) Tsongkhapa considers that the most accurate understanding of what is this illusory 'self' projected on the aggregates is an absolutely crucial step that must not be under-valuated, for even the slightest mistaken comprehension of it entails the inadequacy of the whole process which should culminate with the dissolution of all sufferings. Thus the practitioner must realize that this 'self' that is supposed to be negated by the practice of vipaśyana cannot be simply a vague or inaccurate notion.

Before going deeper into the examination of what this 'self' that is supposed to be negated really is, Tsongkhapa discusses briefly the relation between the negation of the self (or identity) of the person and the negation of the self (or identity) of the aggregates. Exactly as the person is a collection of the aggregates, each one of the aggregates, too, is a collection. The form aggregate is a collection of forms, the feeling aggregate is a collection of feelings etc. Therefore, neither the person, the 'I', nor that which belongs to the person, the aggregates, truly possess a self, or identity. Their identities are construed by the mind in the act of apprehending them as objects of cognition. And, quoting Candrakirti again, Tsongkhapa states that those two cognitions - the lack of the self of the person and the lack of the self of the parts of the person - are deeply connected. You cannot have one of those cognitions without having the other. "At the moment one realizes that the self (bdag, ätman) lacks a nature (rang bzhin - svabhāva), one [also] realizes that the aggregates belonging to the self also lack a self, that is, [they lack] a nature." (TSONGKHAPA, Byang chub lam rim che pa, p. 577) ${ }^{109}$

And here we can see that he equates the notion of a 'self' (bdag, àtman) to that of 'nature' (rang bzhin - svabhāva), using them as synonyms. The notion of a 'self' (bdag, attman), in the sense of 'identity', that is, something that is usually attributed not only to the persons (myself and other persons) but also to all kinds of objects of cognition, as well as the notion of 'nature' (rang bzhin svabhāva), again here in the sense of 'identity' or even 'essence', constitute this mistaken projection that is supposed to be negated by the practice. As a follower of Nāgārjuna, Tsongkhapa naturally equates 'selflessness' to the absence of a nature (rang bzhin-svabhāva). And as he operates this

109 Our translation. 
equation, we start to approach the idea of what this self that must be negated amounts to. But there is still a lot to be understood regarding how Tsongkhapa conceives this 'nature' (rang bzhin svabhāva) that should be negated.

He illustrates the relation between those two cognitions - the cognition of the selflessness of the self and the cognition of the selflessness of the aggregates - with the example of the cognition of the fact that a son of a barren woman does not exist. If one cognizes that a son of a barren woman does not exist, this very knowledge itself removes the possibility of conceiving that his parts exist, such as his legs, feet, head etc. The parts of something that does not exist cannot exist either. With such affirmation Tsongkhapa distances himself from what he considers to be a realist approach, defended by the so-called realist Buddhist schools, according to which, the self of the person is imputed by the mind, but the basis on which this imputation is done, that is, the parts, or the aggregates, do exist by themselves independently of any constructions or imputations by the subjective mind apprehending them. Diverging from such approach, Tsongkhapa sides with Candrakīti restating that "When a chariot is burned, its parts are also burned, and thus are not apprehended [by cognitions]." (TSONGKHAPA, Byang chub lam rim che pa, p. 577) $)^{110}$.

For Tsongkhapa - and he maintains that he is just reaffirming Candrakīrti's position -, those who do not realize the selflessness of the aggregates of the person cannot realize truly the selflessness of the person, because as long as one keeps on apprehending the parts of the person as substantially existing, one will also keep on apprehending the person as substantially existing at some level. Let us analyze briefly the precise meaning of the expression 'substantially existing' (rdzas yod) in this context. The first thing to be observed is that the term 'substantially existing' appears in this treatise as a direct opposite of 'lacking a nature' (rang bzhin mes pa). That means, if something is conceived as substantially existing, it is also conceived as the opposite of something that lacks a nature. In other words, conceiving that something is substantially existing means to conceive that this thing possesses a nature.

Secondly, as the term is related here to the way that the so-called 'realist' schools' supposedly understand the aggregates, we must examine what it means in the context of such realist schools as depicted in the Gelug tenet manuals. According to the Precious Garland of Tenets, the term 'substantially existent' is used by the Great Exposition School (based mainly on Vasubandhu's writings) referring to the "partless particles" and "partless moments of consciousness" (Gön chok jik may wang bo, in SOPA and HOPKINS, 1989, p. 183-186) that constitute the ultimate, or the reality, according to this system. For the Great Exposition School, as well as for the Sūtra School (based on Dharmakīrti's texts), reality is composed of spacial and temporal indivisible atoms, which

110 Our translation. 
are understood as the subtlest level of constitution of phenomena. Our ordinary cognitions, which attribute a singular identity to phenomena, like for instance, 'this is a pot', are seen by those two philosophical systems as conceptual conventions, as explained in the previous part of this thesis ${ }^{111}$. Those two schools, despite their differences, share some common ontological assumptions: 1) as just mentioned, they both assert that the ultimate level of phenomena is constituted of indivisible particles in interdependent relations; 2) the 'identities' of phenomena are construed by our ordinary cognition events; 3 ) the atoms that constitute the ultimate level are considered as existing substantially, that means, at the ultimate level, the atoms exist as such, as indivisible particles, totally independently of the cognition events.

Therefore, we can deduce that the expression 'substantially existing' means to exist in a way which is not construed by the cognitive event, that is, to exist in a certain way, by itself, without any contribution from the perceiving consciousness, much like the concept of 'thing in itself' as described by Kant in modern European philosophy. And since Tsongkhapa equates 'substantially existing' to 'having a nature', we can conclude that 'having a nature' for him means to have a nature which is not construed by the perceiving mind, or to have a nature in itself, independently of the cognitive event, that is, 'having one's own nature', an inherent nature. Considering that this is the meaning that the expression 'having a nature' assumes for Tsongkhapa along the whole treatise, we shall translate it from now onwards as 'having an inherent nature' or having 'one's own nature'.

So the 'realist' approach that Tsongkhapa is opposing here is the one represented by the 'atomistic' ontology defended by the Great Exposition School and the Sūtra School, both of which are considered as proponents of this explicit realist view explained above ${ }^{112}$. The realist Buddhist tenets conceive thus that the aggregates are a 'substantially existent' basis on which the personal self is imputed. The aggregates are substantial, but the person is just a name attributed to the collection.

Generally speaking, all Buddhist philosophical schools assert that the person does not exist concretely, substantially, being therefore just a 'name'. However, there are of course differences in the way that this is understood by each tenet system. According to the realist approach, the idea that the personal self is imputed on the basis of the collection of aggregates is enough to sustain the affirmation that the person does not exist ultimately. But from Tsongkhapa's perspective, the fact that the basis of attribution is seen as substantially existent means that this conception of

111 There are of course many important philosophical differences between those two schools. However, since such differences are not relevant for our discussion now, we shall not present them here.

112 It is important to remark here that, for Tsongkhapa, also the two other tenet systems, the Mind-Only and even some presentations of the Madhyamaka, like Bhavaviveka's one, are considered as still displaying some traces of this 'realist view', inasmuch as they, according to Tsongkhapa, also conceive, albeit not explicitly, a fine trace of phenomena possessing, at a very subtle level, their own nature. In the long section where he discusses the difference between the autonomous reasoning and the consequential reasoning, Tsongkhapa attempts to demonstrates that Bhavaviveka's argumentation still show a very subtle 'unconscious' conception of phenomena possessing their inherent natures. 
selflessness is not complete. This is so because as long as one conceives the basis of imputation, which are the aggregates, as having their own constitutive natures which exist independently of the cognitive event apprehending them, one will also keep on apprehending the person as existing independently of the act of cognitive apprehension at some level. After all, if the aggregates or parts - the basis of attribution - are conceived as having their own natures independent of the cognitive consciousness, then the person itself also has some sort of its own nature, or own being, which does not depend on the mind that conceives it. In this sense, it is not a total negation of the self, because one keeps on conceiving that there is something on the side of the object of cognition which exists by itself with its own nature, independently of the cognitive event, and which serves as a basis of attribution. Those who keep such a view cannot understand that the person lacks a self, or an inherent nature, even ultimately. That means, it does not have its own nature - a nature existing as that nature on the side of the object of cognition - it does not have such 'own nature' in any sense whatsoever. For Tsongkhapa, this is the real meaning of the statement that the person does not exist ultimately. Hence he ends this section saying:

Therefore, this master [Candrakīrti] states that, as long as they (the realists) do not abandon the tenet that the aggregates are substantially existent, they grasp also the person as substantially existent, [and thus] do not realize that the person does not ultimately exist. (TSONGKHAPA, Byang chub lam rim che pa', p. 579) $)^{113}$

We can say that Tsongkhapa applies the negation of the self to all types of conceptions of identities, including the conception of singular indivisible basic particles as being the substantial ground of phenomena. As Dharmakīrti himself states, "the singular is dependent on linguistic convention (samketa)." (PVSV, in DUNNE, 2004, p358) For Tsongkhapa, this idea is extended to all levels of conception of singular identities, wherever those 'singular identities' are supposed to exist. There are no singulars which can be legitimately considered as independent of conceptual conventions, not even when those singulars are postulated as the most minute indivisible particles (atoms) that constitute reality.

113 Our translation. 


\section{The actual establishing of reality}

The section called 'the actual establishing of reality' is subdivided in three main parts which correspond to the three main subject-matters of the whole treatise from now on. The first one refers to the correct identification of the object of negation, which is discussed extensively along many chapters. After this topic has been exhausted, considering that the object of negation has been completely and precisely determined in the text, there comes the second main topic, which deals with the specific kind of syllogism that must be used in order to carry out the real negation in one's mind. And thirdly, Tsongkhapa then describes in details the procedure that a practitioner is supposed to use for the actual establishment of the correct view of reality. Due to our limitation of time, we have been obliged to decrease significantly the explanation of the second main topic, considering that, despite its importance, it is not as relevant as the other topics with regards to the specific question that has guided our analysis. It is presented in chapter VI (Applying the Rational Analysis to Negate Inherent Nature) as a sub-chapter called 'Two Types of Reasoning to Refute The Object of Negation'.

\section{The Need of Identifying Properly the Object of Negation}

The first important point to be established refers to the absolute need of identifying correctly the object of negation, as pointed out in the previous section. Tsongkhapa uses one analogy to clarify what is at stake. If we need to know for sure whether or not one specific person is absent in a room, it is absolutely necessary for us to have a very clear and precise idea of which person we are 
referring to. If someone asks you "Do you know if Mary is not here?" If you do not know who Mary is, you simply cannot answer this question. Similarly, says Tsongkhapa, in order to realize the selflessness of phenomena, one must know the exact meaning of the term 'self', or inherent nature, which we are talking about:

In order to know with certainty the meaning of selflessness, or lack of inherent nature, one must identify well that self, or inherent nature, that does not exist. For, if the generality (spyi, sāmānya) of the object of negation does not appear well [to one's apprehension], one will also not unmistakably ascertain its negation. (TSONGKHAPA, Byang chub lam rim che pa', p. 579) ${ }^{114}$

And Tsongkhapa quotes here a text by Shāntideva that is an authoritative reference for all Tibetan Buddhist scholars, the Bodhisattvacaryāvatāra (byang chub sems dpa'i spyod pa la 'jug $p a)$ : "Not perceiving the attached entity (dngos po), one does not apprehend the absence of that entity." (TSONGKHAPA, Byang chub lam rim che pa, p. 579) $)^{115}$

We must remind ourselves here that the projection of inherent nature onto phenomena is an unconscious mental act. Therefore, although we do it all the time, we are not aware of it. That is why it is necessary to design the contour of the 'attached entity' very accurately, so that the meditator is then able to recognize it in deep introspection before he or she can start with the actual rational process that is supposed to see clearly its character of being a mistaken mental construction. According to Tsongkhapa, the correct recognition of the actual object of negation, that is, of the actual mistaken projection, is something which is not at all to be taken for granted by a serious meditator eager to establish the view of reality solidly in his or her mind. One can very easily mistake it for something which should definitely not be negated, or else, one can also easily negate just the superficial layers of such a deluded projection, while still leaving intact its deepest core.

Tsongkhapa explains these two types of wrong negation as cases of 'falls in the extremes'. There are two extremes that a meditator seeking reality must try to avoid at all costs: the extreme of eternalism and the extreme of nihilism. One who is able to find the 'middle way' between those two, escaping thus from those falls, is considered a genuine Mādhyamika. The term 'extreme of eternalism' refers to the cognitive mistaken conception that conceives phenomena as existing with their inherent natures, that is, as existing in themselves and by themselves, or by the power of their own being. In other words, this is the kind of conception that we have spontaneously about all phenomena. Therefore, what is meant here is that, despite one's attempt to attain the view of reality by means of the practice of vipaśyana , if the practice is not correctly done, one's apprehension of 
phenomena will still continue to conceive things as existing by way of their inherent characteristics, or inherent nature, at some level, even if the grossest part of such a conception has been dissolved. It is similar to the case of the realist schools' tenets mentioned just above by Tsongkhapa: if the aggregates or parts (the basis of attribution) are conceived as having their own natures independent of the mind, then the phenomena themselves (the persons or any other phenomena) are also conceived as having their inherent natures, their own being, which do not depend on the mind that conceives them. This means that those phenomena are conceived as existing by themselves, independently of the perceiving mind, at some some level.

On the other hand, the extreme of nihilism is the view that denies the existence of phenomena. For Tsongkhapa, negating that phenomena have their own natures independent of the cognitive event does not at all mean to negate that they exist. They do exist. But they do not exist by themselves, with their own being, independently of the cognitive event. What should actually be negated by the proper vipaśyana practice according to him is not the existence of phenomena, but only a specific deluded conception of the way that phenomena exist: not existing independently of the cognitive event does not signify 'not existing at all' for Tsongkhapa. Therefore, he points out that those who do not find - in their vipaśyanā practice - the precise point between the conception of 'existing by itself, in itself', on one side, and the conception of 'not existing at all', on the other side, have not found the correct 'Middle Way'.

Tsongkhapa is addressing here some of his contemporary Tibetan Buddhist scholars who "claim to propound the meaning of Madhyamaka (the middle way)" (TSONGKHAPA, Byang chub lam rim che pa, p. 580), but who actually, according to him, have not found that. He classifies their erroneous interpretations of the object of negation in two types: 'the overly broad (khyab che ba) misconception of the object of negation (dgag bya)' and the overly limited (khyab chung ba) misconception of the object of negation'. He starts with the refutation of the overly broad misconception, a subject matter to which he dedicates a large portion of his treatise. This mistaken identification, which leads the mind to the so-called 'extreme of nihilism', could be found, according to him, in the explanations of most of those who taught the Madhyamaka during his time. 


\section{Chapter V}

\section{Misconceptions of the Object of Negation}

The Overly Broad Misconception of the Object of Negation

Tsongkhapa describes this mistaken identification saying that those who propound this view consider that all phenomena are refuted by rational analysis and that objects that have been negated by rational analysis cannot possibly exist. He quotes their position: "... how is it possible for something that has been rationally refuted to exist?" (TSONGKHAPA, 2002, p. 127) First of all, we must clarify what the expression 'rational analysis' refers to. It is a specific type of rational investigation that searches for the ultimate nature of a given object of cognition. Searching for the ultimate nature means searching for the 'self', or 'identity', of a phenomenon, in the sense of trying to locate where exactly this identity, or self, (or nature) is found in the object itself, that is, where this identity or nature exists in the object without any construction on the part of the subjective apprehension. This type of analysis is a procedure which is followed by all those who adhere to Nāgārjuna's Madhyamaka philosophical school. 
Tsongkhapa defines it as "The thorough analysis [that investigates] whether phenomena like forms etc -, in their mode of being objects [of cognition], exist or do not exist, are produced or are not produced, [this kind of analysis] is called 'the reasoning analyzing reality' or 'the reasoning which analyzes the ultimate'." (TSONGKHAPA, Byang chub lam rim che pa, p. 606) ${ }^{116}$ Further ahead in the treatise, he refers to it quite often simply as 'rational analysis' (rigs ps $d p y d$ - rik pe che). Gonsar Rinpoche, in his commentary, explains it as a kind of analysis that "penetrates into the objects [of cognition] in order to understand their ultimate mode of existence." He distinguishes between ordinary search for an object of cognition and the 'ultimate search' with the following example. If one searches ordinarily for a cow, one asks: 'Where is the cow? Is it behind that mountain? Is it behind that rock?' On the other hand, if one is involved in the 'ultimate search', one asks to oneself: 'Where is the cow (or the 'cowness') in the cow itself?' (verbal information) ${ }^{117}$. In order to illustrate how the Madhyamaka rational analysis is carried out, we will reproduce here, step by step, the complete application of rational analysis as it is found in Pabongka Rinpoche's "Liberation in our Hands"118. This type of analysis is known as 'neither-identical-nor-different'. We shall apply it now to the concept of a jug.

When our perception constitutes the jug as an object, we see a singular unit - the jug which seems to possess its nature, or identity, as a jug from its own side. In the process of our ordinary and naive perception of objects of cognition, we have the clear impression that, our mind, like a mirror, simply captures the outer object exactly as it is in itself, just there, complete in its nature, or identity, sort of 'waiting' to be apprehended by our senses. In other words, we have the clear impression that our senses are merely reflecting - as a mirror - the 'inherent nature' that the object already possesses in itself. However, when we examine the object, we can see that its identity, or nature, is composed of many parts. In the case of a jug, it is composed of a base, a top part, a lip etc. We ask then what exactly this 'nature' of the jug is: is it identical to the jug's parts, or is it different from the jug's parts? There are only two possibilities to conceive the nature of a phenomenon: it must be either a unity or a multiple ${ }^{119}$. If the nature of the jug, that is, the fact of its

116 Our translation.

117 Verbal information by Gonsar Rinpoche, 3rd of June 2007, Rabten Choeling. Transcribed from audio recordings of the commentarial explanation about this treatise.

118 Our analysis, which is applied here to the 'inherent nature' of the jug, repeats step by step Pabongka Rinpoche's analysis applied to the 'inherent nature' of the 'I', or self, of a person, in Liberation in our Hands, part three, 2001. The same type of analysis is also found in the final part of Tsongkhapa's treatise which is being analysed in this thesis. However, as the one presented by Tsongkhapa's in this text is much longer and much more detailed, we have decided to utilize here Pabongka Rinpoche's one in order to introduce the procedure of rational analysis to our readers for the first time. Tsongkhapa's presentation, which has as its first object the classical chariot, will be explained in a more extensive way further down in this work. For those who can read Classical Tibetan fluently, Tsongkhapa's Middle Lenght Exposition of the Stages of the Path (lam rim 'bring ba) also presents a more summarized version of the same type of rational analysis, very similar to the one found in Pabongka Rinpoche's Lam rim.

119 In Illumination of the thought' (translated by HOPKINS, 2008) Tsongkhapa expresses this principle: "...whatever are established bases [that is, are existents] do not pass beyond being either one entity or different entities." 
being a jug and not a pillar or a dog, is identical to its parts, then it is a multiple; if it is different from its parts, then it can be conceived as another separate unity.

Regarding the first possibility, if the jug's nature, or the jug's self, and its parts were identical, they could not appear to our mind as being distinct and separate. Instead, they should form a complete unity, impossible of being differentiated at all. Besides, if the jug's self and its parts were identical, it would not be necessary to conceive the self of the jug as separate from the self of the parts of the jug, like the nature of being a jug as separate from the nature of being a lip, from the nature of being a base etc. The very expression 'parts of the jug' would have no meaning, or would be equivalent to saying 'the parts of the parts' or 'the jug of the jug'. It would be senseless to express the identity of one self - as the jug - and the identities of other selves - as the parts of the jug. In other words, it would be senseless to express the concept of the self of the jug as being distinct from the concept of the parts of the jug, as we ordinarily do when we see and analyze the parts of the jug. If the self of the jug were identical to the parts or to the qualities of the jug, such a self of the jug would then become only those parts and qualities and nothing else. Another absurd consequence of the identification of the self of the jug with the parts of the jug is the fact that, since the parts are multiple, the self of the jug, too, would have to be multiple. There would be many 'selves' of the jug.

Regarding the second possibility, the conception of the self of the jug as being different from the parts of the jug also leads to absurd consequences. The first absurd consequence is the fact that, in this case, we should be able to conceive the self of the jug without the parts of the jug. The following analogy clarifies the inconsistency of such a thesis. Suppose we can see now three objects: a desk, a book and a pencil. If the book and the pencil are set apart from the desk and disappear from our sight, we can still point to the desk and say: "That is a desk". In the same way, if the self of the jug were different from the parts of the jug, it should be possible to eliminate the parts of the jug one by one, the base, the body, the lip and the top, and still identify the self of the jug without any of those parts. It should be possible to point to this self of the jug which is supposed to be independent from the base, the body, the lip or the top part, and say: "This is the jug". But it is not possible to identify the being of a jug without the parts of a jug.

Therefore, the self of the jug cannot be conceived neither as being identical to the parts of the jug nor as being different from them. And according Tsongkhapa, the reason for that is the fact that the self, or nature, of the jug does not exist in the object of cognition itself, out there just 'waiting' to be captured by our senses exactly as it is as a self, a unity, a singular nature. Instead, the 
reality is that this self, this unity, this singular nature, is actually construed by the cognitive event. However, this is not the conclusion that those who misconceive the object of negation arrive at. Criticizing this mistaken use of the Madhyamaka rational analysis, Tsongkhapa says:

Analyzing whether something such as a pot is any of its parts - such as its lip or neck - they do not find it to be any of those; this leads them to a sense of certainty that 'there is no pot here'. Then, applying the same analysis to the analyzer, they become certain that 'there is also no analyzer here'. They then wonder, 'If the analyzer is not to be found, then who is it that knows that pots and such do not exist?' So they say, 'Things are neither existent nor non-existent.' (TSONGKHAPA, 2002, p. 139)

Moreover, reminding the reader of the fact that the correct Madhyamaka view is supposed to be attained only after great exertion and long endeavor both in the studies as well as in the application of analytical meditation, he argues saying that such kind of meaningless conclusions, as the one just mentioned, simply cannot be the correct Madhyamaka view, for it does not require more than a quick superficial reasoning to understand it and realize that it does not signify anything. Therefore, he says: "If the false certainty brought on by this sort of counterfeit reasoning were considered a case of finding the Madhyamaka view, then gaining that view would seem to be the easiest thing in the world." (TSONGKHAPA, 2002, p. 139) A little further in the text, he cites another example of such counterfeit conclusions:

They hope to avoid falling to the extremes of existence and non-existence simply by saying, 'We do not claim that things are non-existent (med $p a$ ); we say that they are not existent (yod pa ma yin pa). We do not claim that things exist (yod pa); we say that they are not non-existent (med pa ma yin $p a)^{\prime}$. This is nothing but a mass of contradictions; it does not in the least explain the meaning of the middle way. (TSONGKHAPA, 2002, p. 146)

With the same kind of analysis, they also negate that "production and such" exist (TSONGKHAPA, 2002, p. 127). Negating 'production' means negating that things are produced by causes and conditions. In other words, along with the negation of the existence if single objects of cognition, like a jug, a person etc, they also negate the existence of the causal relation between objects of cognitions. These two negations are, of course, consistent with each other, for you cannot negate the existence of separate objects without negating at the same time the existence of the causal relations between them. After all, if single objects do not exist, how can the causal relations 
between them exist?

In Tsongkhapa's view, conclusions as the ones mentioned above are clear instances of negating more than what is supposed to be negated by the Madhyamaka rational analysis. And he explains the mistake made by those who negate too much. Not understanding correctly the precise meaning of the concept of self, or nature, that is supposed to be negated (which is actually, as just explained, a nature or self that exists as such inherently in the object of cognition), they apply the analysis and conclude that the object itself does not exist, or is just an illusion, since its nature, or self, has not been found by the analysis. However, as Tsongkhapa points out, the conclusion that the phenomenon analysed does not exist, or that it is as illusory as a mirage in a desert, is clearly an absurd. For a mirage in a desert disappears when I approach it and try to touch it, and the water in its spring cannot relieve my thirst, while the jug analyzed here can be touched and used, that is, it has its functionality that certifies for the fact that it is not an illusion in the same sense as a mirage or a dream. In other words, due to not recognizing properly that what is supposed to be negated by this analysis - only the mistaken conception of the existence of an 'inherent nature' in the object of cognition -, they end up negating the object's 'mere nature', that is, a nature that is NOT conceived as existing inherently as such in it, and which corresponds to its functionality.

Hence, Tsongkhapa establishes here a clear distinction between the conception of an 'inherent nature' of an object of cognition and the conception of it as having simply a 'nature'. He clearly states that those who think that negating the [inherent] nature of things destroys the existence of phenomena cannot distinguish between a sprout's lack of nature (rang zhin med pa) and a sprout's non-existence (med $p a$ ) nor between the existence (yod pa) of a sprout and the establishment of the sprout by its own entity ( rang gy ngo bo kyis grub pa) (TSONGKHAPA, Byang chub lam rim che pa, p. 594). He cites Candrakīrti saying that this type of analysis is an investigation that searches for the [inherent] nature (rang zhin, svabhāva) [of phenomena] and explains that this actually means that it is supposed to seek "whether forms etc. are established by their own entity (rang gy ngo bo kyis grub)" (TSONGKHAPA, Byang chub lam rim che pa, p. 607).

Following this short explanation, he makes a clear distinction between 'being established by one's own entity', on one side, and 'mere (tsam) establishment', on the other side. This same distinction appears often along the next pages and is used as having the same meaning as the similar distinctions between 'existence by way of one's own entity (rang gi ngo bos yod pa) and 'mere existence' (tsam yod pa), and between nature ( rang zhin), understood, as explained above, as inherent nature, and 'mere nature'. In other words, the expressions 'being established by one's own entity', 'existence by one's own entity' and 'having an [inherent] nature' all mean the same and are 
differentiated from 'mere establishment', 'mere existence' and 'mere nature'. Tsongkhapa concludes: "Therefore, innumerable mistaken ideas will be overcome if one distinguishes the existence or nonexistence of a [inherent] nature (rang zhin yod med) from existence and non-existence (yod med) [of the object of cognition itself]. (TSONGKHAPA, Byang chub lam rim che pa, p. 606) (20 $^{12}$

However, Tsongkhapa clarifies, those who fail to make this crucial distinction and thus believe that the Madhyamaka analysis is meant to negate the mere existence, or mere nature, of phenomena, actually end up equating phenomena to "the son of a barren woman" or "the horns of a hare", that is, they equate phenomena to "non-things", where, as we have seen in Part Two, the definition of a 'thing' is a phenomenon that can function, or in other words, that is part of the vast causal network, being cause and effect of other things in it. Therefore, says Tsongkhapa, their conclusion is tantamount to affirming that phenomena are "empty of all function", which makes them incur in the "fallacy that dependent-arisings do not exist". (TSONGKHAPA, Byang chub lam rim che pa, p. 611)

Next, he points out the second mistake made by those who negate more than it should be negated. They also fail to distinguish between 'not resisting the rational analysis', on one hand, and 'being destroyed by the rational analysis', on the other hand, as if the Madhyamaka analysis could legitimately empower oneself to deny the existence of phenomena that are unequivocally appearing to oneself and which unequivocally function in some way. He says:

Therefore, not withstanding the analysis with reason [on one side] and to be negated [on the other side], those two (...) and [with this kind of] reasoning mind which is analyzing whether things exist with one's own nature or not, not finding birth, cessation etc, [one one side] and finding the non-existence of birth, cessation etc [on the other side], all these alternatives, not distinguishing them and holding them to be identical, because of this, not only those of the present time, but even some of the earlier wise ones seem also to have generated misconceptions. Therefore, those endowed with intelligence should analyze precisely and distinguish them. (TSONGKHAPA, Byang chub lam rim che pa, p. 609, oral translation by Gonsar Rimpoche) $)^{121}$

Thus the crucial point to be stressed is the fact that the Madhyamaka rational analysis is not at all supposed to negate 'mere existence' (yod pa tsam), but only 'existence of one's own entity' (yod pai rang gyi ngo wo). (TSONGKHAPA, Byang chub lam rim che pa, p. 612) However, how does Tsongkhapa explain 'mere existence', or 'mere nature', as opposed to 'existence (or

121 4th of June 2007, Rabten Choeling. Transcribed from audio recordings of the commentarial explanation about this treatise. 
establishment) by one's own entity', or to the conception of phenomena possessing their '[inherent] natures'? According to him, we must seek the selflessness, or emptiness of [inherent] nature, on the very basis of the conception of dependent origination taught by the Buddha. This doctrine, already mentioned in Part Two of this work, holds that all phenomena arise, or originate, in dependence upon specific causes and conditions. Therefore, if we seek the 'the object of negation' in this view, we must definitely find it as being something that would contradict this doctrine. And the conception of the mode of being of phenomena that directly contradicts it is the conception of phenomena as existing by themselves, that is, as possessing their own 'natures' independently of causes and conditions.

For example, if a sprout possessed its nature of 'sprout' in itself, inherently, such a nature could not have been produced through the action of various causes and conditions. These causes and conditions are, for instances, the fact that a seed has been planted in a fertile soil, and after that, has been exposed to specific conditions, like the correct amount of watering, heat etc. It is precisely because such a sprout does not possess its nature inherently that we can admit that it was originated as an effect of those various causes and conditions. It is also this quality of being empty of an inherent nature that allows the sprout to gradually change into a mature plant, produce grains etc ${ }^{122}$. Therefore, it is exactly because the sprout does not possess its nature inherently that we can see the cause and effect relation really functioning. In this sense, Tsongkhapa affirms that the dependent origination of phenomena is actually "the best reason" we can use to establish the truth of the absence - or emptiness - of inherent nature (TSONGKHAPA, 2002, p. 137) According to him, this union of emptiness - which, in his treatise, means the same as selflessness, or the absence of inherent nature - and dependent origination is a feature that is specific to Nāgārjuna's philosophy. In other words, "the ascertainment of appearances (the diversity of phenomena) and emptiness together, on one basis" is the correct Madhyamaka view of reality (TSONGKHAPA, 2002, p. 132), and it can be found only in the Madhyamaka tenets system. He quotes Nāgārjuna:

'I bow down to the Buddha,

The unequaled supreme teacher

Who taught that emptiness, dependent-arising,

And the middle way hold a single meaning.' (TSONGKHAPA, 2002, p. 133-134)

In the written register of the oral lineage, we find another citation of Nāgārjuna which explains very clearly this union: "'Because those things that arise only mutually dependent on 
causes and conditions coming together are not established by way of their own power or through their own force, the perfect Buddha explained that they are empty of being established by way of their own entities. (...)"' (Four Interwoven Annotations, in NAPPER, 2003, p. 332) The simple fact that phenomena originate in total dependence on so many factors is a proof that they do not "exist as self-powered entities", that is, "they are empty of existing from their own sides" or, in other words, they are empty of being established by their own natures.

This connection between emptiness and dependent origination is also elaborated as the inseparability between the two truths. Tsongkhapa says: "The way to establish that view [the union between emptiness and dependent origination] is to reach certain knowledge of the two truths..." (TSONGKHAPA, 2002, p. 130). The philosophical differentiation between the two truths is found in all four Buddhist tenet systems which are recognized by the Gelug as based on authentically instructions taught by the Buddha. Each one of those systems, though, has their own specific explanation of this distinction. For example, Dharmakīrti's philosophy, according to the Gelug, distinguishes the two truths in terms of the 'specifically characterized phenomena' and the 'generally characterized phenomena'. The Gelug tenet manual by Jang-gya-rol-bay-dor-jay cites Dharmakīrti's Prāmanavārttika: "Whatever ultimately is able to perform a function exists ultimately here [in this system]; other [phenomena, unable to do so] exist conventionally. These set forth specifically and generally characterized [phenomena].” (in KLEIN, 1991, p. 124) In other words, the specifically characterized phenomena, which, as explained in Part Two, are able to function in reality, do ultimately exist, whereas the general representations used by thought and language to deal with the impermanent things, and which are not able to perform real functions in themselves, exist only conventionally. However, both of them are 'truths', that is, they are both valid, since one is real in itself and the other corresponds to reality in a functional way.

The Gelug position, however, since it is based on the commentarial explanations of Nāgārjuna's Mūlamadhyamakakārikā composed by Buddhapālita and Candrakīrti, uses Candrakīrti 's definition of the term samvrti (kun rdzob), usually translated as 'conventional'. According to the Gelug tenet manual 'Great Exposition of Buddhist and Non-Buddhist Views on the Nature of Reality' (1699) written by Jam-yang-shay-ba ${ }^{123}$, in his text 'Clear Words', Candrakīrti mentions three different usual meanings for the term samvrti (kun rdzob). They are: 1) that which obscures the perception of reality, 2) that which is dependently originated and 3) the conventions of the world. (in HOPKINS, 2003, p. 234) Therefore, for the Gelug, a 'conventional truth' is also an 'obscured truth'. Further ahead in Tsongkhapa's treatise, in the part where he discusses in depth the validity of 
the conventional truths, he quotes Candrakirti saying: "Because the nature [of the phenomenon] is covered by ignorance, it is conventional [obscured or relative]" (TSONGKHAPA, Byang chub lam rim che pa, p. 625) $)^{124}$. The term 'ultimate' in 'ultimate truth' (don dam bden pa), in its turn, can be literally rendered as 'the supreme object'125. Hence, an ultimate truth is an ultimate object of knowledge, an ultimate object to be apprehended or understood by the mind.

We can understand the relation between the two truths by applying their meanings, for instance, to the definitions given in Dharmakïrti's tenet system in Part Two. The generally characterized phenomena, which Dharmakīrti considers as samvrti, are obviously conventional, since they are the representations used in language and thought. And they are also 'obscurative' in the sense that they do obscure, or cover, the reality as defined by him, that is, the impermanent phenomena originated continuously in the universal net of causality. We repeat here two quotations utilized in Part Two in order to remind the reader of the 'obscurative' character of the generalities (sāmānya) in Dharmakīrti's philosophy:

Real things are themselves different, but in conceptual cognition they appear as if non-different in that they appear in some single form. Those things appear that way in that their differentiation is obscured by an obscurative cognition which obscures the form of something else [- i.e, those distinct real things - ] with its own form [ i.e., the form of a single image]. That obscurative cognition, although based on those different real things, has the cognitive appearance of a single object. (...) Due to the intention of that cognition, a generality (sāmānya) is commonly said to exist. But it does not ultimately exist in the way that it is conceptualized by that cognition. (DHARMAKīRTI, PV1.68-70, in DUNNE, 2004, p.339)

And:

That awareness is obscurative (samvrti); that is, it obscures the form of something else [i.e., those distinct things] with its own form. In other words, that cognition obscures the difference among those things. (DHARMAKīRTI, PVSV in DUNNE, 2004, p.339-340)

Tsongkhapa's perspective, however, is different from the one presented in Dharmakīrti's philosophy. First of all, the two truths are defined as two types of object of knowledge: "Although there indeed are many different ways of asserting what the basis of division of the two truths is, 
here it is taken to be objects of knowledge." (TSONGKHAPA, Illumination of the Thought, in HOPKINS, 2008, p. 108) The Gelug 'Presentation of Doctrines ${ }^{126}$ defines the two truths in the following way. The conventional truth is "an object [of knowledge] found by a valid cognition that analyzes a convention", and the ultimate truth is "an object [of knowledge] found by a valid cognition that analyzes the ultimate.” (JETSUN CHOGYE GYELTSEN, in PRESTON, 2009) ${ }^{127}$.

The 'ultimate', for Tsongkhapa, is not the infinitesimal particles occupying space and time, like in Dharmakīrti's perspective, but the mere selflessness, or the absence or emptiness of inherent nature in phenomena. The relation between the two truths in the Gelug system is the same one as explained in Part Two between 'impermanence' and 'being produced', that is, they are different isolates of one same entity ${ }^{128}$. That means, in the same way as one existent, for instance, this desk, is 'one same entity' with its impermanence, its 'being produced', its color and its shape, it is also 'one same entity' with its selflessness, or emptiness of nature. "The two truths are one entity but different isolates [that is, one entity but conceptually isolatable], like produced and impermanent thing." (TSONGKHAPA, Illumination of the Thought, in HOPKINS, 2008, p.221). Or in other words, "The two truths are just two aspects of the same thing. They are like two sides of one leaf..." (GONSAR R., 1999, p. 26) ${ }^{129}$.

Applying this articulation between the two truths to the connection between emptiness and dependent origination, we conclude that, as G. Sopa states, “...any dependent arising thing and its being empty of inherent existence are the same nature." (SOPA, 2017, p. 92) They are two isolates within a common locus. As such, we can speak of them also using the logical terms examined previously, namely, pervasion and reversed pervasion. Commenting on a passage of Nāgārjuna's Vigraha-vyavārtini-vrtti, Tsongkhapa says:

Therefore, [Nāgārjuna] speaks very clearly about the pervasion that whatever depends on causes and conditions lacks [inherent] nature and the reversed pervasion that whatever has [inherent] nature does not depend on causes and conditions." (TSONGKHAPA, Byang chub lam rim che pa, p. 589) ${ }^{130}$

Regarding the doctrine of dependent origination, it appears in Tsongkhapa's treatise with 126 Composed by Jetsun Chogye Gyeltsen.

127 Our Translation.

128 Refer to Part 2, pp.46-52

129 That is also how the Gelug interprets the famous passage of the Heart Sūtra "Form is emptiness, emptiness is form. Form is no other than emptiness. Emptiness, too, is no other than form." 
three different meanings, or rather, it is approached in three different levels of dependence. These are levels of subtlety in the description of how phenomena arise in an interdependent way. The first level is the one mentioned above in the example of the sprout, that is, the fact that any given phenomenon is the result of the gathering of many causes and conditions. This is the grossest level of dependent origination: causality. The second one is perceived when we analyze the dependence of a phenomenon on its parts. For example, what I perceive as being myself, or ' $\mathrm{I}$ ', is conceived as such in dependence upon my perception and conception of my body, my mind, the parts of my body, the different parts or manifestations of the mind, like feelings, sense perceptions, thoughts etc. The same relation between the phenomenon and its parts is valid for all other things. A chariot is conceived as a chariot in dependence on all its parts, such as the wheels, the axis, the seats etc., just like a jug is conceived as a jug in dependence on its lip, top part, body etc. And finally, the third and subtlest level of dependent origination refers to the fact that all phenomena - as appearances depend on a subjective awareness to be established as phenomena. In relation to this last level, we find, first of all, Tsongkhapa's quotation of Nāgārjuna's treatise:

'That which arises dependently
Is explained as emptiness
This is imputed dependently;
This is the middle way.' (TSONGKHAPA, Byang chub lam rim che pa, p. 585)

Further ahead in the text, Tsongkhapa himself states:

Question: How does ignorance superimpose intrinsic nature?

Reply: ... in the case of reification by ignorance, there is, with regard to objects, be they persons or other phenomena, a conception that those phenomena have ontological status - a way of existing - in and of themselves, without being posited through the force of an awareness. The referent object that is thus apprehended by that ignorant conception, the independent ontological status of those phenomena, is identified as a hypothetical 'self' or 'intrinsic nature'. (TSONGKHAPA, 2002, p. 212)

Those three levels of gradual subtlety are related also to the increasing grades of difficulty to establish in the mind those views of phenomena as arising interdependently. Although all three of them are ignored when we ordinarily perceive things, the third one is much more difficult to understand and identify. The first level - causality - can be easily understood. In fact, it constitutes

131 Oral translation by Ven. Gonsar Rinpoche, 27th of May 2007, Rabten Choeling. Transcribed from audio recordings of the commentarial explanation about this treatise. 
a kind of ordinary knowledge which is used as a basis for many of our daily activities. As G. Sopa points out, "Farmers know that if they plant corn seeds and provide the other necessary conditions, corn sprouts will grow and when fully ripened will result in a great crop of corn." (SOPA, 2017, p. 94) However, this ordinary knowledge about causality is by no means the same as understanding the emptiness, or selflessness, of phenomena. In order to attain some comprehension of the selflessness of phenomena, one must necessarily add to one's grossest view of dependence, which corresponds to causality, the other two more subtle layers of understanding how phenomena originate in dependence on other factors. Therefore, the union between dependent origination and emptiness can only be gained after one has mastered the two other levels. The subtlest one, specifically, can be understood only as a result of engaging consistently and repeatedly in the rational analysis - described above - that seeks for the ultimate mode of existence of what appears to our cognition. The written register of the oral lineage of commentary brings a quotation of Nāgārjuna's treatise to support and clarify Tsongkhapa's point:

'This dependent designation with respect to things that are only mere aggregations and collections of other causes and conditions - appearing as the meaning of the emptiness of nature - is the middle way beyond the two extremes of permanence, or establishment by own power, and annihilation, or the non-existence of dependent-arising.' (Four Interwoven Annotations, in NAPPER, 2003, p. 332-333)

Tsongkhapa affirms that only authentic Mādhyamikas are able to attain this complete union of the two truths - dependent origination and emptiness - in their view of reality. According to him, all other systematization of the Buddha's teachings end up considering dependent origination and emptiness of [inherent] nature as contradictory. (TSONGKHAPA, 2002, p. 130 ) Or else, even if one thinks one is a proponent of the Madhyamaka view, but instead of showing that one has attained this perfect combination of those two aspects of reality, one shows that, for him or her, the meaning of emptiness is that, ultimately, dependent-arisen phenomena simply do not exist - like those whose mistake Tsongkhapa is criticizing here -, then he warns them that they have not yet encountered the true Madhyamaka understanding of reality. This means that, in the minds of those who have not attained this view, there is no possibility for dependent arisen phenomena and their emptiness to be seen as two sides of the same leaf.

Instead, when one attains a deeper understanding of the first level of dependence, that is, that phenomena originate as a result of the gathering of specific causes and conditions, one has no possibility of seeing those phenomena that originate within the cause-effect relationship as being at 
the same time empty of their own [inherent] natures, or as being selfless, empty of their own [inherent] identity. Opposite to that, phenomena appear as if they MUST have their natures inherently so as to guarantee the efficiency of the causal relation. This is the view of causality that we have ordinarily. According to our ordinary conception, if we think of phenomena as not possessing their natures inherently in terms of 'their own [intrinsic] characteristics', we cannot conceive any of the efficient chains of causality that we ordinarily perceive in the world.

For example, we take the quality of heat as being one essential or intrinsic characteristic of fire, without which a certain phenomenon cannot be conceived as fire. There is no such thing as a cold fire, or as fire without heat. Therefore, apparently, if we deprive the phenomenon 'fire' of the characteristic of heat as belonging to it essentially or intrinsically, there is no way to conceive that when fire is in contact with wood, for instance, it will show the effect of burning it. This is just one illustration of how we ordinarily conceive phenomena as having their 'inherent natures', or 'intrinsic characteristics', to account for their specific 'roles' in the diversity of phenomenal causalities and transformation. Therefore, we ordinarily see things as if their existence and functionality could have no other explanation BUT the fact that each one of them has its nature inherently as this or that, as fire or as water etc. Thus there is no place for seeing the emptiness, or selflessness, of phenomena.

This is what Tsongkhapa means when he says that those two - emptiness and dependent origination - are seen as contradictory, as if it were not possible at all to posit both at the same time. On the other hand, when one generates some view of the emptiness of [inherent] nature through the use of the rational analysis, realizing thus that the identity, or self, of phenomena is construed by the cognitive event, one then is not able to see phenomena as existing nor as functioning in the causeeffect relations. One sees the emptiness as if phenomena simply did not exist nor could fulfill truly their real functioning. In Tsongkhapa's words:

In that case, when one ascertains the non-existence of even the smallest particle of a nature which exists by its own in the phenomena, then, one does not find the place for the certitude of the relation between cause and effect in one's own view. Thus, one has to posit (or accept) those things just for the view of others. (TSONGKHAPA, Byang chub lam rim che pa, p. 590) ${ }^{132}$

Ven. Gonsar Rinpoche explains that the sentence 'one has to posit (or accept) those things

132 Oral translation by Ven. Gonsar Rinpoche, 28th of May 2007, Rabten Choeling. Transcribed from audio recordings of the commentarial explanation about this treatise. 
just for the view of others' means that one has to posit the conventional phenomena and their functionality as something that, for example, only ordinary beings like ourselves perceive, that is, as something that is not seen, or perceived, by those who have attained a higher, deeper, view of reality. So the conventional phenomena and their functionality is something 'for the others', meaning, for those who have not yet gained the Madhyamaka view of emptiness. Generally speaking, those who teach this pseudo Madhyamaka understanding of emptiness assert that the conventional phenomena do not appear anymore to a mind which has attained the awakened state and is perceiving emptiness, because the conventional phenomena are all falsities, or illusions, in the same sense as a mirage in the desert is totally illusory. They affirm that in the state of awakening (Buddha), the mind that sees conventional phenomena ends, and this also brings an end to the conventional phenomena themselves, which then disappear completely. (verbal information $)^{133}$ Therefore, as we can see, this kind of explanation of emptiness leaves no place, in one's own view, to achieve this perfect union of dependent arising and emptiness, which is the real hallmark of the authentic Mādhyamikas.

On the other hand, says Tsongkhapa:

Or, if you do develop a sense of certainty about cause and effect within your own system, then it will be impossible for your system to foster certain knowledge of the absence of intrinsic existence. You will have to find some other way to construe what the Buddha meant in speaking of the absence of intrinsic existence.

(TSONGKHAPA, 2002, p. 138)

According to Ven. Gonsar Rinpoche's commentary, on the other extreme of the disharmony between emptiness and dependent arising, we find the situation in which a practitioner, after generating in his or her mind some kind of ascertainment regarding the fact that phenomena originate through the gathering of causes and conditions, is then not able to keep in one's view the ascertainment of the emptiness of inherent nature. When this happens, it becomes necessary for such practitioner to explain the teachings given by the Buddha about emptiness, like for instance the Prajñāpāramitā Sütras, either as provisional instructions, that is, as teachings which are not definitive and require thus further elaborations, or simply as non valid or non authentic, and which, therefore, have no place in one's system. In both cases, as we see, dependent origination and emptiness of [inherent] nature are seen as contradictory assertions that cannot be united. In such cases, says Gonsar Rinpoche:

133 28th of May 2007, Rabten Choeling. Transcribed from audio recordings of the commentarial explanation about this treatise. 
....as long as this kind of separation remains between the two, instead of one leading to the other, [instead of] one confirming the other, one sees as if there were a kind of opposition between them; therefore, one has to deal with them separately. [In such cases], one has not yet found the Madhyamaka view. (verbal information) ${ }^{134}$

And he clarifies the process for actually generating the proper Madhyamaka view according to Tsongkhapa:

First one has to ascertain the interdependent existence [dependent origination]. Through that, then one ascertains the emptiness. That is the correct way.(...) As one then reaches one's analysis' limit, and gets this view of emptiness correctly, this emptiness will bring along the certitude about the interdependence [dependent origination] again. In this way, then finally one's view will be more and more precise and on the middle, free from extremes from every angle. (verbal information) $)^{135}$

Or, as G. Sopa states it: "Instead of contradicting each other, these two kinds of understanding assist each other. By understanding one, we develop a more powerful understanding of the other, and vice verse." (SOPA, 2017, p. 94) And he reminds us of Tsongkhapa's very concise exposition of the correct Madhyamaka view in his famous and short composition 'Three Principal Aspects of the Path', where he states that when those two understandings - the dependent origination of phenomena and their emptiness of [inherent] nature - cease to take place separately in one's mind and, opposite to that, start to come together, without alternating, then one can consider that his or her vipaśyanā practice has completed the Madhyamaka analysis:

When they come together [emptiness of inherent nature and dependent origination], no longer alternating,

Just seeing dependent origination in a non erroneous way

Destroys how the object is grasped by wrong apprehension,

Then one's analysis of the view is complete. (Lam gtso nam gsum) ${ }^{136}$

Therefore, while a practitioner has not attained this union, he or she is always alternating

134 28th of May, 2007, Rabten Choeling. Transcribed from audio recordings of the commentarial explanation about this treatise.

135 28th of May, 2007, Rabten Choeling. Transcribed from audio recordings of the commentarial explanation about this treatise.

136 Our translation. 
between the two extremes. Moreover, as Tsongkhapa is pointing out in the Lam-rim long treatise, the inability of reaching this union can also be found as mistaken systematizations of the teachings, like the one he has been criticizing through his attempt to demonstrate that it has an overly broad object of negation. This kind of exposition of the Madhyamaka view (by other Tibetan scholars) that completes its rational analysis concluding that the object of cognition analyzed, like the jug or the person, simply does not exist, being as illusory as a mirage, ends up, says Tsongkhapa, presenting an actual internal contradiction in the way that the two truths are asserted by the Mādhyamikas. That is, its presentation of the ultimate truth - the emptiness - affirms that the conventional truths - the appearances - do not exist. According to Tsongkhapa, this kind of internal contradiction in the way that a system is propounding the two truths is found exclusively in such Tibetan expositions that negate too much, and cannot be traced back to any of the original Buddhist philosophical schools that existed in India: "I hold that there is no one from any Indian Buddhist tenet system, Madhyamaka or otherwise, who says 'In my own presentation of the two truths, reasoning directed at the ultimate eradicates conventional objects."' (TSONGKHAPA, 2002, p. 161)

On the other side, this same inability to reach the union between dependent origination and emptiness is found as the second type of mistaken systematization, that is, the one that cannot posit the absence of [inherent] nature due to affirmation of the causal relations as real, like the realist Buddhist schools. Tsongkhapa quotes Nāgārjuna's 'Refutation of Objections' to give us one example of the arguments used by those schools against the Madhyamaka: "If all things are completely without [inherent] nature, then your words also lack [inherent] nature and cannot refute [inherent] nature." (TSONGKHAPA, Byang chub lam rim che pa, p. 585-586). What is at stake here is the fact that, as explained above, according to our ordinary perception, apparently, if we think of phenomena as not possessing their natures inherently in terms of 'their own (intrinsic) characteristics', we cannot conceive any of the efficient chains of causality that we ordinarily perceive in the world.

However, the main objection put forward by the realist Buddhist schools against the Madhyamaka does not refer only to the causal potentialities of phenomena in general. Rather, it touches a crucial point of the Buddhist practice as a whole. In Tsongkhapa's own words: "If all phenomena are empty [in the sense of] lacking a nature which is established by one's own entity, then the presentations of cyclic [existence] (samsara) and nirvana - bondage, liberation etc - cannot be posited." (TSONGKHAPA, Byang chub lam rim che pa, p. 583) ) $^{137}$ This topic is absolutely essential in the context of Buddhist philosophical debates. The teachings about cyclic existence and 
nirvana are the ones that establish the ground for all Buddhist practices. Thus, the objection made by the realist school affirms that the very core of the Buddhist doctrine, i.e., the teachings about the specific chain of causalities that give rise to cyclic existence, or samsara, characterized by suffering, as well as the specific chain of causalities that gives rise to liberation from this cycle, or nirvana, characterized by peace and the absence of all forms of suffering, are contradictory with the Madhyamaka view of reality. These fundamental teachings of Buddhism are contained in the famous Four Truths, a doctrine that all Buddhist schools assume as authentic, contained in the baskets of teachings that are accepted by all Buddhist traditions ${ }^{138}$, and which, therefore, must be tenable in the context of any given Buddhist philosophical systematization. A system which shows contradiction with regards to what the Buddha taught as being truths about how suffering originates (the causes of suffering) and how it can be overcome (the causes to attain the cessation of suffering) cannot be accepted by any Buddhists.

The line of arguments used by Tsongkhapa in order to reply to this type of objections raised by the realist schools goes in the same direction as the argument analyzed up to now, that is, he attempts to demonstrate that the Madhyamaka negation of the [inherent] nature of phenomena does not eradicate the functionality of things. Fundamentally, his argument is again based on the distinction between the [inherent] nature, which is actually what is supposed to be negated by the Madhyamaka analysis, and the 'mere' nature, which should not at all be negated. However, before we advance with the presentation of how his exposition of this issue is deepened and amplified with the discussion of the notion of 'valid cognition' (tshad ma), we must return to the argumentation against his contemporary Tibetan scholars who negate too much in their analysis.

At this point of the text, Tsongkhapa demonstrates that "those who currently claim to teach the meaning of Madhyamaka are actually giving the position of the realists" (TSONGKHAPA, 2002, p. 132). What does Tsongkhapa mean with such an assertion? Certainly he is not unaware of the significant difference between the realist Buddhist philosophical systems and the Tibetan Mādhyamikas of his time whose tenets he is criticizing, that is, he is definitely not unaware of the fact that the realist schools assert the existence of [inherent] nature in phenomena and that those who consider themselves as proponents of the Madhyamaka, on the other hand, assert the very opposite to that.

Nonetheless, points out Tsongkhapa, those who use the Madhyamaka analysis to negate too much and the realist schools are alike in that they both consider that negating the [inherent] nature 
brings with it the destruction of the existence of phenomena and their causal relations. In other words, both consider that the negation of the nature implies automatically the negation of causality (production). Certainly, the difference between those two positions is maintained though. Despite their consideration of the negation of [inherent] nature from the same perspective, they chose opposite positions. The realists chose to assert the [inherent] nature of phenomena and thus (according to their view of what negating the [inherent] nature implies) maintain the validity of the causality, while the Tibetan madhymikas who negate too much chose to negate the [inherent] nature of phenomena despite the fact that this, according to them, also means negating their production, that is, causality. Tsongkhapa sides with the realists regarding this topic, considering that negating the existence of the causal relations destroys the ground of the Buddhist practice, which is established in the Four Truths, and is therefore totally unacceptable.

Due to the limitation of time for the accomplishment of this project, we cannot provide here an in-depth clarification of the way Tsongkhapa extensively explains the Four Truths in previous parts of his long Lam-rim treatise. Yet, it is necessary to present at least a very concise scheme of such causal relations in order to elucidate Tsongkhapa's position. First of all, let us make some brief observations regarding the notion of causality for the Gelug.

The Yongdzin Dura ${ }^{139}$ defines 'cause' (rgyu) as "anything that assists in or causes production" (Yongdzin Dura, in KHENSUR RINPOCHE, 2005, p. 94). The definition of an effect ('bras bu) is "that which is produced" (Yongdzin Dura, in KHENSUR RINPOCHE, 2005, p. 158). Regarding the causes, that which 'assists in' is called a 'cooperating condition' (lhnacig rkyen) while that which causes is the 'substantial cause'. The 'substantial cause' is explained as 'the principal producer of an effect in its substantial continuum" (Yongdzin Dura, in KHENSUR RINPOCHE, 2005, p. 98). We must remind ourselves here that the Gelug concept of substance (rdzas) (taken from Dharmakīrti) does not refer to an identity-substratum of contingent qualities, but simply to an effective phenomenon, that is, a phenomenon that is produced by causes and conditions, and that also produces effects ${ }^{140}$.

139 A classical Gelug manual of funndamental philosophical concepts. Refer to Part Two.

140 Dharmakīti uses the term 'substance' - dravya - in the context of the Buddhist ontology, which, as already explained, conceives reality as a continuous flow of a vast cause-effect network. In such a context, for Dharmakirti, a 'substance' is an effective phenomenon, that is, a phenomenon that is produced by causes and conditions, and that also produces effects. The possibility of producing effects and undergoing changes is the characteristics that alone defines whatever is real or not real, and the word 'substance' is used by Dharmakīrti to denote what is real in opposition to what is unreal. Real things are those which by definition have causal potentialities and therefore are able to perform causal roles. The Geluk school, accordingly, also uses the word 'substance' (rdzas), but applied only to effective phenomena, that is, to constantly changing momentary events which are causally effective. (DREYFUS, 1997, p. 53-57). Refer to note 46 in Part Two. 
A substantial continuum is explained as a chain of phenomena arising one from the other, depending, of course, on the efficiency of the present cooperating conditions, and which maintain very similar causal potentialities. Khensur Rinpoche gives the following example:

"...fertilizer cannot turn into a sprout, nor can heat, water, earth or air and so forth. Only a seed can turn into a sprout. Therefore, a sprout is of the substantial continuum of a seed. Seeds turn into sprouts and become plants, which in turn produce more seeds that likewise can be planted to produce other plants, and so on." (KHENSUR RINPOCHE, 2005, p. 99)

Therefore, there are 'substantial causes', like seeds, for instance, and 'substantial effects', like sprouts. Substantial causes can also be 'material causes', like the metal or clay that is used for making a jug. The substantial cause is that phenomenon (cause or producer) which is directly transformed into a new phenomenon (effect or produced). On the other hand, the cooperating conditions, also sometimes called 'secondary causes', are those factors of production whose efficiency in the production of a given phenomenon does not set up a continuum of the same substance, that is, a continuum of similar causal potentialities. In the example of the seed and sprout, the cooperating conditions are the earth, heat, air, water etc, whose presence together assist in the production of a sprout from a seed. In the example of the jug, the cooperating conditions are the tools, other auxiliary materials, the human specific ability or knowledge to make it, the human effort exerted etc. Not all things (effective things - dngos po) have a continuum; sound, for example, does not.

The Gelug manual goes on providing further more detailed classifications of types of causes, conditions and effects, offering thus a very broad spectrum of different combinations between phenomena in their relationships, which keep on producing continuously new phenomena in the vast net of dependent origination. There are, for example, non-interfering active causes, co-arising causes, concomitant causes, ripening causes etc, as well as object conditions, governing conditions immediately preceding conditions etc, and ripened effects, dominant effects etc. Those ongoing combinations give rise continuously to new things (effective things - dngos po), also called 'composed phenomena' ('dus byas).

Let us now briefly present how the origination of suffering is explained using this Buddhist model of complex causality. The first and principal seed from which suffering is produced is the one already described at the beginning of this section. It is 'marigpa' in Tibetan (Sanskrit: avidyā), which means 'lack of knowledge', or 'lack of awareness', of reality (dekhonanyid, tattva), that is, of 
the ultimate mode of existence of oneself and all other phenomena. In other words, it is the lack of awareness of the selflessness (or emptiness) of oneself and all phenomena, or the mistaken projection of an illusory self onto phenomena that actually lack it. From this root mental state of distorted apprehension of objects of cognition, two first main subsequent distortions arise: attachment ('dod chags) and aversion (khong dro). They arise as a result of the gathering of specific conditions along with the root cause, 'marigpa'. In other words, they are produced only when specific objects of cognition are apprehended by a cognitive event in which 'marigpa', the fundamental misapprehension, is also active. They are called afflictions (nyon mongs, kleśa), denoting thus the fact that they are states of mental suffering, from their very subtle manifestations up to the very intense feelings of greed or hatred, for example, that can be clearly recognized as afflicted (suffering) mental states even by ordinary beings totally untrained in introspective observation of their minds. Moreover, according to the appearance of diverse specific conditions, such mental states can motivate actions which are clearly sources of more and more experiences of suffering for oneself and others.

But how does it happen that a mistaken cognition can give rise to attachment and aversion? At a very subtle level of constructive apprehension of phenomena, we conceive the 'I' as having an inherent nature, that is, as being established by its own entity, which is the same as conceiving that it is established, or that it exists, independently, just by itself. This very subtle distorted misconception is the opposite of the reality, it is the opposite of the way in which the 'I' really exists, which is as a dependent arising. It exists, or is established, moment by moment, as a result of causes and countless conditions, first of all. Secondly, it exists, or is established, as the conception of an identity - the 'I' - in dependence on its parts (body, mind, feelings etc). And thirdly, it exists as a generic image, or as the name 'I'. In the process of construing this generic image, or this name 'I', our perception separates, or isolates, this 'I' from the vast flow of continuously arising and disintegrating phenomena that actually give rise to this 'I'. Our process of cognition also separates it from the subtle mental act of designation that construes it as the identity, or self, 'I', making us thus believe that it exists just by itself, as if our cognition just captured it and mirrored it exactly as it is in itself. Our perception does this with all phenomena. As we misapprehend our ' $I$ ' in this way, projecting an inherent nature, or inherent identity, on a dependently originated phenomenon that actually lacks that, a very subtle mental affliction of attachment, grasping, arises in relation to this misconceived 'I'. And following that attachment to the misconceived 'I', there comes aversion towards anything that seems to threaten its 'misconceived existence' as something that is not one construed identity. 
Let us use one analogy to try to make it clear. Suppose we make a beautiful sand sculpture on the beach. It is obviously a dependently originated phenomenon. It came into being through causes and conditions, like the human effort exerted in the work, the tools used to mold the sand, the sun light that made it possible for us to see clearly and thus accomplish it according to our design, and if we go further, it depended also on the food that we ate that day, which provided the physical energy for the work and so on. After completing it, we feel fascinated by its beauty and start to cultivate this wish to keep it for ever as it is, we feel attachment for it, wanting to transform it into a stone sculpture and bring it home to be able to appreciate its beauty every day. But then it suddenly starts to rain, and the action of the water drops on the sand makes our sculpture slowly be transformed into a totally different phenomenon. So we immediately feel some aversion for this rain, even some slight anger, thinking, 'I wish so much it did not rain so that I could continue to appreciate my sculpture'.

Or else, we can think of what happens to us when we watch a movie ${ }^{141}$ and feel attachment or even strong desire, for some things that we see, and fell aversion, or even intense hatred, for other things. In reality, as we all know, none of the things that we see in a film exist in the way that they seem to exist in the film. This does not mean that those things do not exist at all, but simply that, when we are captured by the magic of the film, we totally forget the way in which those things really exist, that is, we forget that the people we are watching are actors acting as this or that character, we forget that the homes, clubs, restaurants and even some landscapes are just scenery, we forget the screen, the film director giving instructions to the actors, the script, the amount of time spent in rehearsal and preparations and so on. Therefore, everything we see in the film has a dependently originated existence much vaster than what we conceive and believe during the moments that we feel totally captivated by the story. And as we believe that the story is really happening right now and that every single thing exists there exactly as we are aeeing them, we start to feel attachment, desire, aversion, hatred, fear etc. If the story suddenly stopped and we could see the film being made, with the director giving instructions, the scene being repaired, the actors acting totally differently from their characters etc, if we suddenly could see the whole thing, those intense feelings of attachment, anger or fear would immediately vanish.

This example has the purpose of showing how much the sphere of our emotions is directly conditioned by the way we cognize things. Depending on our cognitions and on the way we are conceiving phenomena, starting with our own 'I', those emotions can arise in different degrees of intensity or simply not arise. This does not mean that when meditators see dependent origination

141 This analogy was used by Gonsar Rinpoche at a course at Rabten Choeling, 11th of August 2017. 
and emptiness they lose the ability of having emotions. That is not the case. Those two spheres, the sphere of the cognition and the sphere of the feelings are deeply connected. The difference is that, according to the descriptions of the true meditators, when one attains the view of dependent origination and emptiness, the mind is totally filled with very intense bliss, ecstasy, a very intense feeling of happiness that is totally free from all subtle traces of afflictions, disturbances or sufferings. Hence, it is not a matter of eradicating emotions, but only of eradicating 'afflicted emotions' (nyon mongs, kleśa), that is, emotions which are intrinsically bound with either manifest or potential sufferings. Moreover, it is important to note that those processes are all gradual, that is, as a meditator gradually develops his or her correct view of reality, correspondingly, the 'afflicted emotions' gradually decrease their intensity and their manifestations. Actually, this should be used as an empirical criterion for a meditator to check whether or not he or she has been directing the meditation to the right target, that is, if the actual object of negation has been really hit. In case the correct misconceived 'I' is being properly negated by the analysis, then the immediate result should also be felt in the sphere of the 'afflicted emotions', that is, one should experience their gradual decrease up to their total cessation.

By the way, it is also necessary to observe at this point, that the Buddhist causal explanation of the origin of suffering and of its cessation is not supposed to be approached as a mere theory to be discussed about only in rational terms. Rather, its real purpose is empirical, that is, a practitioner must put all this into practice and experience personally the reality of such causal productions and cessation. According to tradition, this cessation was attained by the Buddha, the awakened one, who was able to observe the very subtle mental activities in his own mind, and eventually gain total control over them. And it was passed on from master to disciple for many generations, that is, many great meditators have used these methods and obtained the expected results, too, if not the complete cessation of all suffering, at least very advanced levels of partial cessation or significant decrease. In other words, the final criterion for one's appreciation of the methods is one's own personal experience of its functionality.

As we can see, the same model of causality that explains the origin of suffering is also used to account for the way suffering can be overcome. First, the prerequisite practices must be completed up to the attainment of perfect concentration as described at the beginning of Part Three, which also depends, as already mentioned, on the correct application of a gradual method for overcoming the innate mental tendencies towards distraction and sinking. The application of this method is, of course, also based on causal explanations of how to antidote our ordinary capacity of very low concentration. Briefly, all Buddhist practices are based on causal explanations of how to 
use specific methods and conditions to enhance our mental capacities. And finally, the practice that leads directly to the dissolution of the root of all suffering processes is the 'vipaśyanā' (lhag mthong) analysis of reality combined with śamatha (zhi gnas), or perfect concentration. Through that, a gradual dissolution of the habitual projection of an [inherent] self or nature on the person (and on phenomena in general) is accomplished.

The total dissolution of this habitual projection is called 'cessation', referring to the fact that this root cause of suffering has been ceased, and with that, all mental states which are characterized by suffering, also cease. In other words, when the root cause ceases, even though conditions may appear, that means, the objects of cognition which, in the presence of the root cause, produce, together with it, attachment, aversion etc, even though they may continue to appear to that mind, since the root cause is not present anymore, the afflicted emotions are no longer produced, exactly as a sprout cannot be produced if there is no seed in the ground, even though the conditions - heat, water, fertilizer etc. - may be present. Therefore, causality, or dependent origination, is the ontological basis on which all Buddhist practices are designed. Hence, says Tsongkhapa, it cannot be negated by any consistent Buddhist philosophical systematization. It is absolutely crucial to keep the validity of dependent origination.

Particularly, Tsongkhapa mentions the practices of the Bodhisattvayāna, or Mahāyāna, which are supposed to combine activities to benefit sentient beings in various ways (and eventually guide them to the final state of cessation of all suffering) with a deep realization of emptiness (selflessness) of persons and phenomena. According to him, such practices, which are taught in the Prajñāpāramitā Sütras, for example, cannot be genuinely carried out by a practitioner who has not attained the union of dependent origination and emptiness of [inherent] nature in his or her own vipaśyana practice, for, if the mind stays only on the extreme of emptiness in the comprehension of reality, without uniting this view of emptiness with the view of dependent origination, as explained above, in that case, such a practitioner, negating thus the existence of objects of cognition and their production (or causal relations), will not be able to engage properly in those various Bodhisattva activities which are based on the view of dependent (causal) production of phenomena. Indeed, if a practitioner's view is conceiving production of phenomena as non-existent, how can he or she engage genuinely in the production of phenomena? That is, how can he or she engage correctly in activities which are supposed to produce benefits for sentient beings?

Or else, on the other hand, if marigpa does not produce the mental afflictions and the mental afflictions do not produce sufferings and actions that produce more sufferings to oneself and 
others, then why should a Buddhist practitioner follow specific ethical codes of behavior which are designed exactly with the purpose of avoiding the production of mental afflictions like greed and hatred, for instance, which then produce actions guided by greed and hatred that, in their turn, produce more and more sufferings to oneself and others? A genuine Buddhist practitioner is supposed to avoid the cultivation of the 'mental afflictions' and the actions motivated by them during their whole practice up to the moment when their true complete cessation is attained. However, if one negates the existence of objects of cognition and their production, one automatically negates that greed and hatred produce sufferings as well as actions that also produce sufferings for oneself and others, and hence one has no ontological ground on which to establish one's ethical conduct. In other words, one has no real reason why one should exert so many efforts aiming the total eradication of those afflicted mental states, since they are seen as not really producing anything, that is, as not having any harmful effects. Therefore, ontologically negating the existence of objects of cognition as well as their causal production has far reaching consequences, and for this reason such a view must definitely be avoided.

Regarding this topic, we must also mention that the ethical codes of behavior within the Buddhist context are not external moral rules that a practitioner should follow due to obedience to one hierarchical or divine authority. Rather, ethical conduct is supposed to be the conduct adopted due to one's own personal authentic understanding of how suffering originates, attained as a result of one's personal pondering, analysis and reflection. In other words, a person who has not genuinely understood that, for instance, greed and hatred produce sufferings, will not genuinely adopt a conduct that truly avoids the production and encouragement of such mental states nor the encouragement and production of actions guided by such mental states. Therefore, according to Tsongkhapa, the path of the Bodhisattvayāna must be grounded on the practitioner's personal attainment of the view of reality that unites dependent origination with the emptiness of [inherent] nature. 


\section{Mere Nature}

The 'mere nature', or 'mere self', is the self or identity which, as mentioned above, exists as a dependently originated phenomenon established as such through the three levels of dependence already explained. In some Gelug contemporary texts, it is usually referred to as 'conventional self' (or conventional nature); sometimes it is called 'relative self' (or relative nature). According to Ven. Gonsar Rinpoche's explanation ${ }^{142}$, this relative or conventional nature of phenomena appears, in our ordinary perception, totally mixed with our habitual innate projection of an inherent nature, or inherent identity. Therefore, deep introspection, or observation of one's mind during the process of cognition, must be exerted for quite a long time before one is able to develop the capacity to distinguish clearly between those two types of nature in one's apprehension of phenomena. Tsongkhapa says: "Reflecting carefully, you must identify the intrinsically existent person as it is imputed by the ignorance in your mind-stream." (TSONGKHAPA, 2002, p. 304) Only after those two types of identity have been clearly distinguished in the process of cognition, should a practitioner then apply the rational analysis to negate the inherent nature, or inherent self. G. Sopa says:

... innate ignorance (marigpa) holds the self to be inherently existent. (...) This combination - of an ordinary object and its way of being grasped by innate ignorance - is the so-called object of innate ignorance. This is what needs to be negated. The ordinary object itself should not be negated. (SOPA, 2017, pp. 240241)

That means, if the procedure is done properly, the meditator should realize that, although the application of the analysis has dissolved the mistaken projection of the inherent nature, the cognition of the conventional, or relative, nature (the dependently originated nature) is still valid. In this sense, quoting Candrakīrti, Tsongkhapa asserts: "Candrakīrti negates valid cognitions and objects of perception which are established by their own entities; he does not negate valid cognitions and objects of perceptions that are posited as dependently originated." (TSONGKHAPA, 
Byang chub lam rim che pa, p. 617) ${ }^{143}$

Discussing extensively Candrakīrti's ideas and defending his presentation of the Madhyamaka, Tsongkhapa affirms that the realist schools conceive the valid cognitions as valid in a way that is essentially different from the way proposed by Candrakīti - which is the conception that Tsongkhapa agrees with. According to him, the realist schools consider valid cognitions as nonmistaken inasmuch as they are thought of as correctly apprehending characteristics which exist inherently in the object of cognition. However, according to Tsongkhapa, regarding specifically the perception of characteristics as existing inherently in the objects of cognition, valid cognitions are actually mistaken, deceptive and therefore, invalid. For example, when we ordinarily cognize a table, we perceive a specific shape, color etc., and we end up imputing the name 'table' to such an object due to our judgment that it is able to perform the functions of a table. But, together with all this, we also 'perceive' these characteristics as if they belonged intrinsically to the object, that is, as if our own process of cognition, our consciousness, simply mirrored it exactly as it is in itself, without adding anything to it nor having anything to do with the construing of the single object. Therefore, says Tsongkhapa, valid cognitions are mistaken and deceptive in relation to this aspect. However, they are deceptive regarding this aspect alone, which means that their validity in relation to the specific functionality pointed out by the cognition can still be maintained. In other words, the fact that they are valid regarding the judgment about their causal potentialities does not mean that they must also be valid in relation to the fact that such objects are apprehended as if they existed inherently, or as established by their own entities.

According to Tsongkhapa, it is not adequate to simply superimpose to the ordinary notion of epistemological validity - which refers specifically to the adequacy of a certain name and concept to a certain cognition due to its correspondence to a given type of functionality -, it is not adequate to superimpose on this kind of epistemological validity the added belief or assertion that this validity necessarily implies the ontological fact of such an object of cognition being established, or existing, by its own entity, or with its characteristics belonging to it inherently or essentially. In other words, epistemological validity must be circumscribed only to the sphere of the object of cognition's correspondence to specific types of functionality. In this sense, epistemological validity must not be used as a means to assert anything regarding the object's mode of existence. He establishes here a clear border between those two domains.

The so called 'conventional consciousnesses', that is, the ordinary consciousnesses that 
cognize 'this is tree', 'that is a table', 'it is a lemon tree', 'it is a round table' etc. are classified as 'nonanalytical consciousnesses'. This does not mean that this type of consciousnesses does not analyze at all. Tsongkhapa says that those consciousnesses can also inquire, of course. Bu they inquire, or examine, only within the sphere of how conventional objects of cognition work or function, or of how they relate to each other. What Tsongkhapa means when he calls them 'non-analytical' is that they do not engage in the rational analysis that seeks specifically for the real mode of existence of those things, for the actual way in which they are established to us as objects of cognition. In other words, the ordinary conventional consciousnesses do not have the ontological question in their horizon, they do not investigate the ultimate reality of those things that appear to us. Their function is the mere recognition of a presence in our field of perception and cognition, the mere recognition of a presence without investigating how this presence has come about. In his own words:

In a sense, conventional consciousness operates in a non-inquisitive manner. It operates only within the context of how a given phenomenon appears to it, without analyzing, 'Is this how the object actually exists, or does it just appear this way to my mind?' [628] It is called non-analytical consciousness, but it is not the case that it is utterly non-inquisitive. It operates within the context of how things appear, how they are known, to a worldly or conventional consciousness. It does not operate via analysis of how things actually exist. (TSONGKHAPA, 2002, p. 178)

And he adds that what non-analytical consciousnesses really relate with "is the perceptual or experiential basis for the construction of conventional language" (TSONGKHAPA, 2002, p. 179), making it clear that, up to this point - but just up to this point - he does agree with Dharmakirti about how language is created. He does not agree with him, however, regarding the assertion that valid cognitions are based on characteristics that exist inherently in their objects.

Tsongkhapa defends a different position, presenting his view as the correct interpretation of Candrakirti's ideas. For him, the simple fact that the sensory consciousnesses are unimpaired, that is, they are not being affected by any external nor internal causes of error, is enough to account for the validity of perceptual cognitions. Quoting Candrakīrti, he provides a list of conditions that can impair the sense faculties. The internal conditions can be cataracts, jaundice, sleep etc. up to the consumption of intoxicants that affect and distort the sensory data. During the sleep, for example, dreams make a person perceive things which do not exist in reality. In this sense, dreams are classified along with those circumstances that induce mistaken perceptions. After one wakes up from a dream state, one realizes that the objects perceived in the dream do not have any functionality any more; therefore, they are conceived as non-valid cognitions. The external 
conditions include mirrors (which present objects of cognition as if they existed in a place where they do not exist, since they are mere reflections), water (when it reflect things), sounds inside caves (which produce echoes), the sunlight at specific places and times (it can cause mirages or other distorted perceptions) etc. Therefore, conventional cognitions can be classified in two types: non-distorted ones and distorted ones.

A set of three criteria is provided in order to determine what exists conventionally or not. A cognition is considered as corresponding to something that exists conventionally when: 1) it is cognized by a conventional consciousness; 2) it is not contradicted by any other conventional consciousness which is considered as a valid cognition; 3) it is not contradicted by an analytical consciousness that seeks for the actual mode of existence of that object. The first criterion does not require an explanation. The second one is quite easy to understand. Tsongkhapa uses the classical examples in Buddhist philosophy: seeing reflections, having optical delusions, seeing a rope and judging it at first as being a snake, thinking that a mirage is real water etc. Let us analyze the snake/ rope instance. In this case, one sees something coiled and, at first, thinks it is a snake. However, a subsequent cognition that is then proven to be valid, that is, that shows adequacy between the general image of the object and the behavior or functionality commonly, or conventionally, attributed to this image, contradicts the first judgment. Therefore, one concludes that the first cognition - that conceived a snake - does not correspond to the conventions, since the general image of 'snake' indicates a functionality different from the behavior that one ends up finding in that object. That is the meaning of the conclusion that the snake, in this case, 'does not exist conventionally'; a rope exists conventionally in this case. He says:

As for consciousnesses that perceive things such as a double moon or a reflection, objects such as those which appear to them - two moons, a reflected face and the like - do not exist; [624] this is established by conventional valid cognition itself without relying on a reasoning consciousness. Thus, it is appropriate that these wrong sensory consciousnesses and the five valid sensory consciousnesses be differentiated as incorrect conventional consciousnesses and correct conventional consciousnesses. (TSONGKHAPA, 2002, p. 173)

Note that the expression 'reasoning consciousness' used in the sentence 'this is established by conventional valid cognition itself without relying on a reasoning consciousness' refers specifically to the analytical consciousness, that is, the consciousness that uses rational analysis to seek for the ultimate mode of existence. Therefore, it does not mean that there is no reasoning at all involved in that process. The following quotation makes it clear: 
For example, a consciousness that does not analyze how things actually exist may think that a rope is a snake or that a mirage is water. However, conventional valid cognition does contradict the objects apprehended by such consciousnesses, so those objects do not exist even conventionally. (TSONGKHAPA, 2002, p. 179)

Regarding the third criterion - something that exists conventionally cannot be contradicted by the Madhyamaka rational analysis (that seeks whether an object of cognition has an inherent nature or not) - Tsongkhapa draws our attention here to the fact that it is necessary to distinguish between "(1) not being contradicted by an analytical consciousness and (2) being established by an analytical consciousness." (TSONGKHAPA, 2002, p. 179) Conventional phenomena are not established by an analytical consciousness, that is, they are not in the least established by the Madhyamaka rational analysis, although they are necessarily also not contradicted by it. They are not contradicted by it, because, for a phenomenon to be contradicted by the Madhyamaka rational analysis, it must be posited as existing by the force of its own entity, that is, as existing with its inherent nature. Conventional phenomena are conventional, that means, they are posited as dependently-originated, they are posited as the opposite of what the Madhyamaka rational analysis can contradict or negate.

Conventional phenomena are also necessarily not established by the Madhyamaka rational analysis because, in the context of this type of analysis, if the object which is sought is found, this means that it has an inherent nature, that is, by definition, it is not a conventional phenomenon. Conventional phenomena are established by conventional consciousnesses, that is, by consciousnesses that adequately subsume phenomena to general images that do correspond to the functionality that they demonstrate to be able to perform. This explanation is based on Dharmakīrti 's epistemology, which was explained in Part Two. The difference is that Tsongkhapa does not accept the ontological assertion, present in Dharmakīrti's texts, that partless particles, or atoms, that exist substantially, that is, independently of the cognizing event, are the ultimate real substratum that causes the sensory data to arise in us.

Regarding this point, Tsongkhapa mentions the philosophical schools - both Non-Buddhist as well as Buddhist - that posit the existence of certain phenomena as existing by the force of their own entities or inherent natures, that is, as not dependently-originated phenomena. He calls those phenomena 'imaginary constructs' (TSONGKHAPA, 2002, p. 180) and gives some examples: a divine creator (not caused by anything prior to it) and a primal essence (again not caused by 
anything prior to it) are cases of such phenomena posited by the non-Buddhist schools. Some Buddhist schools, on the other hand, posit the existence of partless particles, or atoms, like we find in Dharmakîrti's and Vasubandhu's writings. According to the philosophical assertions of those schools, such phenomena are posited as existent because they have been proven by rational analysis, that means, they are considered as having been discovered by rational analysis. However, says Tsongkhapa, when we apply the Madhyamaka rational analysis on them, they are not found ${ }^{144}$. This means that the Madhyamaka rational analysis contradicts their existence. Therefore, they fall in the category of phenomena that are contradicted by the Madhyamaka rational analysis, and because of this, they are classified as non-existent. Tsongkhapa affirms:

When they [the non-Buddhist and Buddhist schools] posit such, they do so after rational analysis of whether those things essentially exist; they think that this sort of rational analysis will discover these things. Thus, because they assert that these things can withstand rational analysis, they have to accept that others, outside of their schools, can perform such rational analysis in order to discover whether these things intrinsically exist. When analyzed in this way, such things cannot withstand the pressure of inquiry by impeccable reasoning. Thus, when reason does not find them, they stand refuted - for if they did exist, such reasoning would have to find them. (TSONGKHAPA, 2002, p. 180)

Tsongkhapa considers that those three criteria constitute a firm boundary that guarantees the possibility of positing conventional phenomena correctly, that is, as valid cognitions that, although valid, are not asserted to exist by the power of their own entities. He says:

We posit forms, sound and such only as they are known to conventional consciousnesses that are not impaired by internal or external causes of error. We do not assert them as part of a system in which an analysis of whether they are mere conventions or instead have objective existence will find that they are essentially or intrinsically existent. ${ }^{145}$ (TSONGKHAPA, 2002, p. 180)

144 As G. Sopa remarks, obviously their conceptions of rational analysis are different from the Madhyamaka rational analysis. 145 Our underlining. 


\section{The Overly Limited Misconception of the Object of Negation}

Dependent origination, as stated above, is the view of reality that correctly antidotes the mistaken projection of a self, or inherent nature, onto phenomena. And, as mentioned, it includes three levels: dependence on causes and conditions, dependence on parts and dependence on conventional designation. In the part of the treatise called 'Refuting an Overly Limited Misconception of the Object of Negation', Tsongkhapa addresses some defenders of the Madhyamaka view who propound to antidote the innate mistaken projection of a self using only arguments that oppose the first two levels of dependent origination. For example, they use only arguments that state that phenomena which are dependent on causes cannot be said to possess an inherent nature, or self. Indeed, this is definitely true. However, Tsongkhapa points out, such kind of approach does not identify the fundamental Madhyamaka object of negation. Other Buddhist schools also antidote the false notion of a self in phenomena using this kind of argument. Other Buddhist schools also assert that "compounded phenomena are produced by causes and conditions", and as such, are continuously changing.

According to Tsongkhapa, this kind of argument antidotes only one aspect of the false projected self, namely, its permanence. In other words, meditation on this, can negate only the self as a permanent phenomenon, and nothing else. Therefore, says Tsongkhapa, this cannot be considered as the sole Madhyamaka object of negation. Although negating the self as a permanent phenomenon is definitely necessary, it is still a very superficial level of negation, that does not challenge the real, and deeper, root of the mental afflictions and sufferings. Hence, those who negate only this aspect have a limited misconception of the object of negation:

Since the partisans of non-Madhyamaka Buddhist schools have already established that compounded phenomena are produced by causes and conditions and are mutable, we should not have to demonstrate to them the absence of intrinsic nature. They also should have recognized that things lack intrinsic nature. So how can this be the unique Madhyamaka object of negation? (TSONGKHAPA, 2002, p. 196) 
Moreover, negating the self based on arguments that demonstrate the second level of dependence, that is, dependence on parts, does not touch the deepest core of marigpa either. What does it mean, in the context of the Madhyamaka view, to assert that phenomena depend on parts? The realist schools, as mentioned, advocate the idea that phenomena are composed of minute partless particles, or atoms, which are not directly perceptible by the ordinary human capacity of cognition. The Mādhyamikas, however, do not agree with that. They use the argument that, if a particle occupies some space, no matter how minute, it can certainly be divided into eastern, western, southern and northern parts. Therefore, it cannot be considered truly as partless. On the other hand, if one asserts that the minute atoms do not occupy any space, then, the Mādhyamikas ask: how can spaceless particles sum up and give origin to things that occupy space? Therefore, as explained previously, the idea of the existence of partless particles as the ultimate substratum of phenomena is considered by Tsongkhapa - along with the notion of a non-caused divine creator or non-caused primary substance - as an 'imaginary construct'. Besides, such ideas cannot be the fundamental innate marigpa because they are not innate at all. Nobody is born with the philosophical assumption of the existence of atoms (nor of the existence of a divine creator). These are philosophical constructions which one acquires at a mature age due to the contact with specific speculative doctrines. Hence, since they are not innate, they cannot be the root marigpa that gives rise to attachment, aversion and all the sufferings as explained by the Buddha. Tsongkhapa says:

... even if you determine that those partless things lack intrinsic nature and then meditated on that, this would not at all counter the ignorant conception which has operated from beginningless time. Therefore, even optimal and direct knowledge of that would not overcome the innate afflictions. (...) '... make your principal task to determine that an object as conceived by innate igorance does not exist. Ancillary to that, refute objects of acquired misconceptions. (TSONGKHAPA, 2002, p. 196)

In brief, if the innate mistaken projection of a personal self is not properly addressed, what is negated by the rational analysis are only the most superficial aspects of the construed self: its character of being permanent, unitary and independent. On the other hand, when one uses the rational analysis to negate the self of objective phenomena (instead of the personal self) what is truly negated are only ideas that have been acquired by exposition to philosophical systems. None of these negations can have the least effect in the sphere of the mental afflictions and the sufferings. Tsongkhapa affirms that if we remain on this level only, we establish "nothing more than this shallow selflessness". He says:

Therefore, even if you actualized such a selflessness in meditation and consummated your meditation of it, nothing would come of it. It would be 
extremely absurd to claim that you can overcome innate afflictions by seeing as non-existent the two selves imputed by acquired misconceptions. (TSONGKHAPA, 2002, p. 196)

That does not mean that those so-called 'acquired misconceptions' do not have any relation at all with the root innate marigpa. Actually, for Tsongkhapa, they represent more superficial layers of projections of the innate marigpa, that is, of the innate mistaken projection of inherent nature or inherent existence. In this sense, he says that they are "merely superimpositions based on this [the innate marigpa]" (TSONGKHAPA, 2002, p. 211). 


\section{Chapter VI}

Applying the Rational Analysis to Negate Inherent Nature [self or identity]

The Actual Object of Negation

Among the three levels of dependent origination, two have already been discarded as not representatives of the root innate marigpa. We can deduce now that the innate mistaken apprehension of phenomena refers thus to the third, and most subtle or profound, level of dependence, that is, to the fact that phenomena arise in dependence on conventional designation by the apprehending mind. Tsongkhapa says:

Therefore, what exists objectively in terms of its own essence without being posited through the power of a subjective mind is called 'self' or 'intrinsic nature'. The absence of this quality in the person is called the selflessness of the person; its absence in phenomena such as eyes, ears and so forth is called the selflessness of objects. (TSONGKHAPA, 2002, p. 213) 
Actually, marigpa, as we can see, is a general category, since it includes both the attribution of a self to persons as well as to phenomena [other than persons]. Tsongkhapa explains that the one that arises first is the misapprehension that mistakenly attributes an inherent nature to phenomena other than the persons. That means, first we attribute an inherent nature to the aggregates. We wrongly perceive the body, feelings etc. as having an existence, or a nature, which is independent from our cognition and conceptual designation of them. On the basis of this deepest mistaken projection, we then project an inherent nature to our own person as a composite of those aggregates. Tsongkhapa speaks here of a 'cause and effect relationship' between the first and the second mistaken projections, that is, the mistaken projection of 'inherent natures' to the aggregates causes us to do the same regarding our person. Then, a mistaken conception that thinks 'I' is generated.

Therefore, marigpa, which here can be said to mean 'misapprehension' or 'faulty apprehension', is a general category that indicates this mistaken projection of a false self or inherent nature. The specific 'faulty apprehension' that generates the mistaken sense of an inherently existing 'I' is a case of the general category of marigpa, and it is called, as explained at the beginning of Part Three, 'the view of the perishing collection', or the 'view of the perishing aggregates'.

This specific view is identified as the root of the mental afflictions and all the sufferings. On the basis of the misconception of the 'I', the aggregates are again misconceived, but now, not only as inherently existing, but specifically as inherently existing 'mine'. In this way, the 'view of the perishing aggregates', which misconceives the 'I' and 'mine', is completed. When we speak of the 'mine' (my aggregates, that is, my body, my feelings etc) as misconceived by this view, we are still speaking of the projection of an inherent nature to the person, and not to phenomena. G. Sopa explains it in the following way. When we conceive, for example, the body as having an inherent existence as 'mine', the conception of the 'I' as inherently existent must also be present. He says:

"When we think 'this is my hand', first there is the thought 'hand' and then the
thought 'mine', which is that hand in connection with 'me'. (...) Without 'me', 'mine'
cannot appear. So when we grasp 'mine' as inherently existent, we are also grasping
'me' as inherently existent'. Therefore, the main object of the grasping at 'mine' is
'me'; so grasping at 'mine' is the grasping at a self of persons". (SOPA, 2017, p. 291)

Such innate and deep misconception of the 'I' and 'mine' should not, however, be confused here with the mere conception of the 'I' and 'mine'. The innate misconception of the 'I' is characterized by the fact that this ' $\mathrm{I}$ ' is apprehended as having a nature of its own, as having an identity in itself and by itself, that is, it is apprehended as something that exists by the force of its 
own entity without being posited or construed conceptually as an identity by the cognitive event. In Tsongkhapa's words: “...since a view of the perishing aggregates is a conception of the person as essentially existent, it is a conception of an 'I' that exists by way of its intrinsic character." (TSONGKHAPA, 2002, p. 214) He insists that it is necessary to distinguish clearly between the false 'I' that exists by its own entity and the mere 'I', and that only the inherently existent 'I' must be negated by reasoning:

...[the word] 'self' refers to essential or intrinsic existence and also refers to the object of an awareness that simply thinks 'I'. Of these two, the former is the object negated by reason, whereas the latter is accepted conventionally, so it is not refuted. (...) ... you do not refute the object which is observed by the innate view of the perishing aggregates. However, the way that its aspect is apprehended is as an essentially existent ' $\mathrm{I}$ ', so it is not that you do not refute that way of apprehending. (TSONGKHAPA, 2002, p. 215) (46 $^{146}$

G. Sopa explains it using the epistemological concepts of two different types of object in the cognitive event. He calls them the 'held object' and the 'basic object'. Using the example of the debate about the impermanence of sound, he says that those who do not conceive sound as impermanent hold as their object of cognition 'sound as permanent', or 'permanent sound'. This is their 'held object'. However, there is another object of this cognition, which he calls the 'basic object' and refers simply to 'sound'. The attribute 'permanent' is actually added to the 'basic object' when sound is conceived as permanent. He says: "the held object is the combination of the basic object and the attribute" (SOPA, 2017, p. 288). 'Held objects' can be either false or true. The conception 'impermanent sound' is also a 'held object'.

In relation to our ordinary cognitions that conceive phenomena as having a nature in themselves, G. Sopa says that it is the same process. We add the 'inherent nature', or 'inherent existence', to the basic object, which is the mere phenomenon, that which appears to us. We thus constitute the 'held object' as, for example, 'a table with its inherent nature as a table', or 'a table that exists as such by itself and in itself', or, in other words, 'an inherently existent table'. G. Sopa explains again: "The held object is the conventional object grasped in this incorrect way - as inherently existent" (SOPA, 2017, p. 288). The 'basic object' - the mere table - is not supposed to be negated; only its false attribute of existing inherently should be negated.

In brief, the actual object of negation is our innate, ordinary and naive unconscious way of perceiving phenomena as existing independently of our cognition of them, independently of our mental processes that categorize and name them according to this categorization, as if their 
identities as 'this' or 'that' stood in themselves, and our perceiving mind just passively mirrored such 'natures' or 'selves'. G. Sopa says:

When we identify things ordinarily, we do not think they are established by the power of our mind in any way. (...) ... the innate mind of ignorance holds them to exist from their own side, through their own reality or way of existing. (...) ... the grasped object, as it is held in this way by innate ignorance, is called 'self' or 'nature'. (SOPA, 2017, p. 284)

Two Types of Reasoning to Refute The Object of Negation

After the discussion about the correct object of negation has been completed, leaving the reader with a precise idea of what mistakes should be avoided, Tsongkhapa moves on to the next subject matter to be treated, which deals with the specific kind of reasoning that must be utilized by a meditator when applying correctly the Madhyamaka rational analysis in order to induce an inferential cognition of emptiness. He tells us that Tibetan scholars distinguished between two types of Mādhyamikas, classifying them as either 'Prāsangika (thal 'gyur pa) Mādhyamikas' or 'Svātantrika (rang rgyud pa) Mādhyamikas', according to the type of reasoning used by them in the procedure of the rational analysis. Tsongkhapa states that such a distinction was not fabricated by Tibetan scholars, but actually is in conformity with Candrakīrti's important work Clear Words (Prasanna-padā) (TSONGKHAPA, 2002, p. 116).

First of all, it is necessary to clarify the very basic meaning of the terms 'Prāsangika' and 
'Svātantrika'. In a debate, the word 'Svātantrika' refers to the use of 'autonomous' arguments, while Prāsangika' refers to the commitment to use only arguments that demonstrate the inconsistent consequences of the opponents' statements. We can therefore use the English terms 'autonomous reasoning' and 'consequential reasoning' to translate the Sanskrit and Tibetan words. The 'autonomous' reasoning corresponds to the structure of the syllogism analyzed in Part Two of this thesis: all produced things are impermanent; sound is produced; therefore, sound is impermanent. The 'consequential' reasoning, in its turn, can be defined as a reasoning that ends up concluding the absurd consequences of the accepted assumptions, usually explicitly following the model "if ' $x$ ', then it follows that ' $y$ '", where ' $y$ ' is always an unacceptable logical consequence. The same elements of the autonomous reasoning can be put in a different way so as to form a consequential reasoning. For example, to antidote a mistaken assumption that sound is not impermanent, one may use the consequential reasoning 'If sound is not impermanent, it follows that sound is not produced (unproduced)'. Such a reasoning will be effective to shake the person's wrong assumption that sound is not impermanent in case this person already conceives that all permanent things are necessarily 'not produced', although he or she may not have yet verbalized it nor ascertained such a pervasion. Gonsar Rinpoche explains it:

For someone who also accepts sound being produced [the fact that sound is a production], and that whatever is produced has to be also impermanent, and that what is permanent has to be also uncreated [non-produced], and knowing that sound is created, but still holding sound to be permanent. For somebody like that, if one gives this consequential reasoning, it makes the other person think and see that his assumption is wrong. It shakes the other person's wrong belief. (Verbal Information) $)^{147}$

As mentioned in Part One, the distinction between Prāsañgika and Svātantrika Mādhyamikas has its origin in the great Indian commentaries to Nāgārjuna's work Mūlamadhyamaka-kārikā (MMK). The first great Indian Buddhist scholar to comment on Nāgārjuna's MMK was Buddhapālita (ca 470-ca 540 CE). Buddhapālita's commentary uses the same type of reasoning found in Nāgārjuna's text, that is, reasonings that demonstrate the untenable consequences of the philosophical assumptions put forward in order to answer specific philosophical questions. Buddhapālita's commentary and interpretation of Nāgārjuna's MMK was criticized by another great Indian scholar: Bhāvaviveka (ca. 500 - ca. $578 \mathrm{CE}$ ). Bhāvaviveka criticized Buddhapālita stating that Mādhyamikas should not limit their reasoning only to the effect

147 Verbal information by Gonsar Rinpoche, 19th of June 2011, Rabten Choeling. Transcribed from audio recordings of the commentarial explanation about this treatise 
of demonstrating the untenable consequences of assumptions, but instead, should use positive argumentation to establish the Madhyamaka philosophical view. The next great Indian Buddhist scholar to enter this debate was Candrakīrti, who lived in the seventh century. He also composed an important commentary to Nāgārjuna's MMK, called Prasannapadā Madhyamakavrtti. Candrakīrti's commentary defends Buddhapālita's position against Bhāvaviveka's critiques.

According to Tsongkhapa, the debate regarding these two different ways of presenting the Madhyamaka's position occupied the attention of many Madhyamaka scholars. He makes it clear that he does not intend to discuss all of them: "There have been many ways of defining Svātantrika and Prāsangika arguments; who could explain all of them? That is why I focus on only a few of them." (TSONGKHAPA, 2002, p. 226). He then proceeds to explain four presentations of this debate, that is, four different articulations of the precise manner those two different types of arguments work and of the reasons that justify, legitimately or not, either the use of the autonomous arguments or the advice to avoid them. He dedicates many pages to the detailed clarification of these four presentations and to his own personal refutation of each one of them. Due to our limitation of time we cannot present here this part of the discussion, which is quite dense and long, but shall proceed instead directly to Tsongkhapa's own explanation of the difference between the two types of arguments and to his own conclusion regarding whether or not it is appropriate for Mādhyamikas to use autonomous reasoning when attempting to establish (or prove) the emptiness of phenomena.

First of all, it is necessary to mention one distinctive aspect of the so-called 'autonomous reasoning', as it is explained by Bhāviveka according to Tsongkhapa's description of Bhāviveka's position: all the elements of the syllogism, that is, the subject, the predicate and the reason, must be established as elements that appear in common to both parties involved in the debate. What does it mean for the elements of the syllogism to appear in common to both parties? Citing passages of Candrakīrti's Clear Words, Tsongkhapa gives us one example to show what this means. In a debate between a Buddhist scholar and a debater from a non-Buddhist school, the elements of the thesis 'sound is impermanent', for instance, which are 'sound' and 'impermanent', must be taken in a general sense, that is, "not with specific qualifications". The term "specific qualifications" refers to the specific philosophical positions the each party holds regarding that specific element. That means, one school considers 'sound' as a "quality of space", that is, as constituted of the substance of space ${ }^{148}$, whereas the other school (the Buddhist school) considers that sound originates from the interdependence of the four elements (wind, fire, water and earth). Obviously, if each school 
establishes its own conception of 'sound' as the subject to be debated about, there will be no debate, for the other school will not accept it right from the beginning. Therefore, according to Bhāviveka as read by Tsongkhapa, the subject - as well as the other elements - must be a 'general' one, in the sense that it must comprehend only conceptions which are accepted by both parties. In Tsongkhapa 's words:

Therefore, it is impossible to use as a subject something that is incompatible with one's own belief system. For, given that the subject is the basis that both parties analyze in order to see whether a specific quality is present, it has to be something established as appearing in common to both. (TSONGKHAPA, 2002, p. 253)

Therefore, in the case of the syllogism 'sound is impermanent because it is produced', the subject 'sound' must be taken by both debaters in its general sense, that is, as simply 'sound' and not as it is specifically understood by the different schools represented by two parties. Moreover, Tsongkhapa states that, for Bhāviveka, the meaning of 'establishing the elements as appearing in common' refers to the idea that both parties must establish those objects of cognition (the subject, the predicate and the reason) with the same kind of valid cognition: "That is what Bhāviveka thinks: to establish as appearing in common means that the proponent and the opponent use the same kind of valid cognition to establish it." (TSONGKHAPA, 2002, p. 253)

However, explains Tsongkhapa, when it comes to the use this type of syllogism to prove the emptiness of inherent existence, something that Bhāviveka has not mentioned enters the scene. The proponent of the emptiness of inherent existence is a Mādhyamika. The opponent, that is, the person to whom this Mādhyamika is supposed to 'prove' (or establish) the emptiness of inherent existence is a debater belonging to any other Buddhist philosophical school, since only the Madhyamaka school advocates such a tenet. And we must bear in mind here that 'proving', or 'establishing', in this context means actually, as Geshe Sopa puts it "engender further understanding” (SOPA, 2017, p. 360). That means, if the proponent is successful, the opponent should be sincerely convinced of the truth of the emptiness of inherent existence, that is, he or she should engender this realization, this understanding, genuinely in his or her mind-stream. Tsongkhapa points out that, using the 'autonomous reasoning' there is no real chance of proving the emptiness of inherent existence to an opponent, due to the simple fact that, from the outset, both parties in this case cannot establish the elements of the reasoning as appearing in common, that is, as appearing to both as established by the same kind of valid cognition. 
We must remind ourselves here that, as explained previously, according to Tsongkhapa, all other Buddhist schools conceive the valid cognitions as valid in a way that is essentially different from the way proposed by the great Mādhyamika Candrakīrti (as read by Tsongkhapa), and which is the conception that Tsongkhapa agrees with. That is, the other Buddhist schools consider valid cognitions as non-mistaken inasmuch as they are thought of as correctly apprehending characteristics which exist inherently in the object of cognition. However, from Tsongkhapa's perspective, regarding specifically the perception of characteristics as existing inherently in the objects of cognition, valid cognitions are actually mistaken and deceptive.

That is, when we ordinarily cognize something, like a book, for example, we perceive a specific shape, color, functionality etc., and so we attribute the concept 'book' to such an object due to our judgment that it is able to perform the functions of a book. However, in this process of cognition, we also end up conceiving those characteristics as if they belonged inherently to the object, that is, as if our own process of cognition, our consciousness, simply mirrored it exactly as it is in itself, without adding anything to it nor having anything to do with the construing of the single object. Therefore, says Tsongkhapa, valid cognitions are mistaken and deceptive in relation to this aspect. Certainly, valid cognitions are neither invalid nor mistaken regarding the specific functionality pointed out by the identification of the object. Nevertheless, the fact that they are valid regarding the judgment about their causal potentialities does not mean that they must also be valid in relation to the fact that such objects are apprehended as if they existed inherently, or as established by their own entities. Actually, this is an 'added ontological belief' that accompanies our ordinary cognitions, but to which we should not give any credit, for such added ontological belief is precisely our fundamental delusion - marigpa -, it is precisely the very object that must be negated in the vipaśyana (lhag mthong) meditation.

Therefore, as the notion of valid cognitions for Mādhyamikas is essentially different from the notion of valid cognition of the other Buddhist schools, it is not possible for a Mādhyamika to use autonomous reasoning to prove emptiness of inherent existence to adepts of the other schools, because there is no way of establishing the elements of the reasoning by the same kind of valid cognition accepted as a 'general' common appearance by both parties. There is no general, common, identical appearance of the elements for those debaters. For the adepts of the other Buddhist schools, the elements of the syllogism appear as validly established as objects of cognition that exist in themselves, and this specific point is totally out of question for them, since it is included in their very definition of what a valid cognition really is. On the other hand, for the Mādhyamikas, this very aspect that is totally out of question for the other party, and which cannot 
thus be abstracted from their conception of the valid cognition of the elements of the reasoning, is exactly the point that the Mādhyamikas want to prove to them. Tsongkhapa says:

... when both the opponents of essential or inherent existence [that is, the Mādhyamikas] and the realists [that is, the adepts of the other Buddhist schhools] posit visible forms as the subject of a syllogism, non-mistaken perception does not establish it as appearing in common to both parties in the debate. Therefore, since there is no valid cognition attesting to a subject that is proven to appear in common for both systems, there will inevitably be a fault in any position that you try to prove to an opponent using an autonomous reasoning. (TSONGKHAPA, 2002, p. 257)

In other words, in the example that used 'sound' and 'impermanence', it was possible for the different schools to accept the 'general' notion of sound, that is, a concept of sound that is not specified regarding whether it is a quality of space or whether it originated from the elements wind, fire, water and earth. But in the case where a Mādhyamika wants to prove the emptiness of inherent existence, the establishment of such 'general' elements is not really possible, because there is no general visible form, for example, that is neither 'non-mistaken' nor 'mistaken' regarding its aspect of being apprehended as inherently existent. It is not possible for the non-Mādhyamika to abstract this 'non-mistaken' characteristic, as it is also not possible for the Mādhyamika to abstract his or her conception of the cognition as being mistaken regarding its imputation of inherent existence to the object. A 'general' notion of a visible form would have to be a visible form which is established neither by a mistaken valid cognition (mistaken regarding inherent existence only) nor by a nonmistaken valid cognition. And such a general notion is not accepted by neither of the parties.

In this sense, Tsongkhapa states that “...one would already have proved the absence of intrinsic nature to the essentialist [realist] while establishing the subject." (TSONGKHAPA, 2002, p. 261) Gonsar Rinpoche explains the meaning of this sentence: if the Mādhyamika's valid cognition of the subject of the syllogism, for example, a visible form, is accepted by the opponent as being 'in common', then, at that very moment, the emptiness of inherent existence of such a visible form is immediately proven to this opponent, since the Mādhyamika's valid cognition of this visible form includes in itself the conception that, despite being valid, it is definitely mistaken regarding the attached implicit ontological belief that it exists in itself. If it is 'in common', this means that the opponent is also apprehending it in the same way as the proponent (the Mādhyamika). Therefore, when the Mādhyamika establishes this subject - the visible form - as appearing in a mistaken way regarding its appearance of inherent existence, the opponent must also establish it in this same way. 
Hence the autnomous reasoning would become useless.

The fact that Bhāviveka advocates the use of autonomous reasonings to establish emptiness leads Tsongkhapa to conclude that, despite being a Mādhyamika, he actually does accept that conventional phenomena possess their natures in themselves. Otherwise there would be no sense in asserting that the elements of the reasoning are established in common with the opponents. Tsongkhapa says:

There are Mādhyamikas - such as the master Bhāviveka - who accept that, conventionally, phenomena have essential or intrinsic character. The conventional existence of essential or intrinsic character is their reason for accepting autonomous reasoning in their own system. Whether one posits autonomous reasoning in one's own system finally depends upon what one posits as the extremely subtle object of refutation. (...) Otherwise, if they accepted that those consciousnesses are mistaken, then what valid cognition would establish the elements of a syllogism as appearing in common for both their system and that of the essentialists [realists]? (TSONGKHAPA, 2002, p. 261)

According to Gonsar Rinpoche, what Tsongkhapa is saying here is that Bhāviveka's "strong adherence to this kind of reasoning is due to his adherence to the conventionally inherent existence of the things". On the other hand, those who do not accept the autonomous reasoning for establishing emptiness, that is, those who advocate the use of consequential reasonings only (when proving emptiness) - and who are thus called Prāsangikas - do not accept the use of autonomous reasoning for proving emptiness "because they do not accept even conventionally any kind of inherent nature of the things existing from their own side. So it all finally depends on that, that is, on this subtle object of negation" (verbal information) ${ }^{149}$. Hence, as Newland points out (NEWLAND, 2008, p. 78), it is not only a difference regarding one specific type of methodology the autonomous reasoning -, but also a difference in relation to the conception of the object to be negated, which means that there is undoubtedly a significant distinction in the way that those two Mādhyamikas - Bhāviveka and Candrakīrti -, as read by Tsongkhapa, present their views of emptiness. Tsongkhapa sides with Candrakîrti, considering that he is the one that is actually presenting the Madhyamaka view in the most precise way. As Newland puts it:

On Tsongkhapa's reading, Bhāviveka's form of madhyamaka is one in which

149 Verbal information by Gonsar Rinpoche, 20th of June 2011, Rabten Choeling. Transcribed from audio recordings of the commentarial explanation about this treatise. 
existence and intrinsically existence are tacitly assumed - though never explicitly asserted - to be one and the same. Existence/intrinsic existence does not hold up under the analytical pressure of madhyamaka reasoning. But Bhāviveka seems to believe that conventionally, without ultimate analysis, things do exist intrinsically - just as they appear to our healthy senses. (...) Tsongkhapa, following Chandrakirti, rejects autonomous syllogisms precisely because he rejects the intrinsic nature that others take as implicitly confirmed in the process of establishing the subject and premises of an autonomous syllogism. (NEWLAND, 2008, p. 83)

Finally, it is important to observe that, for Tsongkhapa, this commitment to use only consequential reasonings when proving emptiness does not at all imply that Prāsangika Mādhyamikas do not assert any thesis of their own, that is, that they are committed only to refuting the philosophical assertion of others. Actually, Tsongkhapa dedicates some time to refute this view, which he considers to be a misinterpretation. To those who affirm that autonomous reasoning must be avoided by Mādhyamikas when analyzing reality because Mādhyamikas do not really assert the thesis that there is no inherent nature, Tsongkhapa answers saying that, if consequential reasoning does not establish a thesis - which is the affirmation of the absence of inherent nature in a given object of cognition being analyzed -, in that case, consequential reasoning, for the same reason, cannot refute the thesis according to which the object of cognition does possess a nature in itself. In other words, at the very moment the consequential reasoning refutes the thesis 'this object of cognition possesses a nature in itself, it also establishes a thesis, which is 'this object of cognition DOES NOT possess a nature in itself'. This is definitely also a thesis. Therefore, if one considers that consequential reasoning can refute the philosophical view that asserts the existence of inherent nature, one must also admit that, for the same reasons, consequential reasoning can also establish the correspondent thesis, which is the lack of inherent nature. He says: "If you think that affirming the absence of intrinsic nature must, without a doubt, negate intrinsic nature, then it should also be the case that negating the existence of intrinsic nature must, without a doubt, similarly affirm the absence of intrinsic nature." (TSONGKHAPA, 2002, p. 235) And, of course, if one affirms something based on the conclusion of logical reasoning, this is what we call 'a thesis'. Therefore, for Tsongkhapa, the assertion that phenomena lack inherent nature is most certainly a philosophical position, a philosophical tenet or thesis. Moreover, it is a thesis for which he has argued extensively along the whole treatise. 


\section{Analyzing a Chariot - Showing that a Chariot Exists Imputedly in that it Lacks an Inherent Nature}

Tsongkhapa introduces the application of the rational analysis to the chariot stating that the Buddha himself used this as an example to show how the personal self is imputed in a dependent way. Through understanding that the phenomenon 'chariot' does not possess an inherent nature as a 'chariot', but actually arises as such due to a nominal/conceptual imputation, it will become easier for a practitioner to apply the rational analysis to his or her own personal self later. Citing Candrakīrti's Commentary on the 'Middle Way', Tsongkhapa announces that he will explain how the Madhyamaka rational analysis demonstrates in seven ways that the chariot does not have a nature in itself: "A chariot is neither asserted to be other than its parts, nor to be non-other. It does not possess them. It does not depend on the parts and the parts do not depend on it. It is neither the mere collection of the parts, nor it is their shape.” (TSONGKHAPA, 2002, p. 279)

The demonstration consists in showing that the chariot does not exist in neither of the seven ways in which it would necessarily exist in case it did possess its own nature as a chariot. As G. Sopa expresses it, "If a chariot were inherently existent, then it must be findable, in relation to its parts, as an entity in its own right." (SOPA, 2017, p. 426) Let us remind ourselves one more time that the purpose of this analysis is not the negation of those seven relationships if they are conceived in terms of relationships between a mere conventional chariot with its mere conventional parts. What is supposed to be negated are the relationships between an inherently existing chariot and its inherently existing parts. The seven relationships are the following:

1) the chariot is not 'one with its parts', in the sense that it is not identical to its parts;

2) the chariot is not 'other' than its parts, in the sense that the chariot is not an entity separate from its parts; 
3) the chariot does not exist as a basis for its parts;

4) the chariot does not exist as dependent on its parts, in the sense that the parts would be the basis on which the chariot exists;

5) the chariot does not possess its parts;

6) the chariot is not the mere collection of its parts;

7) the chariot is not the shape of its parts arranged together.

The first and the second relationships negated repeat the same steps as we previously explained in the analysis of the jug. The Madhyamaka rational analysis starts by asking what exactly this 'inherent nature' of the chariot is. Is it identical to the chariot's parts? Or is it different from the chariot's parts? In case the inherent nature of the chariot is identical to its parts, then it must be multiple, that is, as there are many parts that compose the chariot, if the chariot's nature is identical to those many parts, it follows that there must be many 'natures' of the chariot. In other words, the nature of the chariot, in the sense of an identical single nature - one identity existing from the chariot's own side - would have to be conceived as multiple identities or natures, like the wheels, the basket, the saddles etc., each one also existing from its own side. Besides, if the chariot 's nature and its parts were identical, it would not be necessary to conceive the nature of the chariot as separate from the natures of the parts, like the nature of being a chariot as separate from the nature of being a wheel, from the nature of being a saddle etc. The expression 'chariot's parts' would have no meaning, or would be equivalent to saying 'parts of the parts' or 'chariot of the chariot'. It would be senseless to express the identity of one self or nature - as the chariot - and the identities of other selves or natures - as the parts of the chariot, like the wheels, basket, saddles etc. Or else, because the chariot's nature is a single unit existing from its own side, if the chariot's parts were identical to this single unit, it would follow that those multiple parts should also be a single unit. Therefore, we conclude that this 'inherent nature' of the chariot cannot be identical to the chariot's parts.

On the other hand, if the chariot's inherent nature is said to be different from its parts, that is, if it is not identical to its parts, then it must be conceived as a separate unit. The first absurd consequence of such a statement is the fact that, in this case, we should be able to conceive the nature of the chariot without the chariot's parts. We repeat here the same analogy that we used previously in the analysis of the jug to clarify the inconsistency of such a thesis. Suppose we can see now three objects: a desk, a computer and a book. If the book and the computer are set apart 
from the desk and disappear from our sight, we can still point to the desk and say: "That is a desk". In the same way, if the nature of the chariot were different from the chariot's parts, it should be possible to eliminate the parts one by one, the wheels, the basket, the saddles etc., and still identify the nature of the chariot without any of those parts. It should be possible to point to this nature or self of the chariot which is supposed to be independent from the wheels, the basket, the saddles etc., and say: "This is the chariot". However, it is not possible to identify the nature of a chariot without the parts of a chariot. Therefore, the chariot's self or nature "does not exist from its own side neither as identical with its parts nor as separate from them." (SOPA, 2017, p. 426)

The third and fourth possibilities refer to positing the relationship between the inherently existent chariot and its inherently existent parts as the relationship between an inherently existent basis and the inherently existing things that dependent on that basis. Regarding the third one, Tsongkhapa says: "A chariot is not the basis for its parts, like a bowl holding yogurt..." (TSONGKHAPA, 2002, p. 279). G. Sopa explains this negation in the following way. First of all, it should be stressed here again that, from the perspective of the mere conventional existence of phenomena, surely we consider that a conventionally existent chariot depends on its parts since, as previously explained, the chariot is actually construed as an identity on the basis of an imputation made on its parts. Nevertheless, if we try to imagine that this relationship exists between a chariot which has an inherent nature as a chariot and parts that also possess their own inherent natures in themselves, we will conclude that this type of dependence cannot be posited, because if a chariot has its chariot's nature in itself, then, by definition, its chariot's nature cannot depend on anything else which is not the chariot itself.

From the perspective of inherent existence - existence by one's own entity -, the basis and the things that depend on that basis must exist necessarily as different entities, like 'yogurt inside a bowl'. The yogurt is supported by the bowl, and in this sense, in this situation, it is dependent on the bowl. The bowl is the basis and the yogurt depends on it, it exists in it. Therefore, if a chariot existing as a chariot by itself were such a kind of basis to its inherently existing parts, then, it would follow that, the chariot and the chariot's parts would have to exist as separate entities like the bowl and the yogurt. We would have to consider that the parts, with their inherent natures as a wheel, a saddle etc., exist inside the chariot, which also would have its inherent nature as a chariot totally separate from the parts. Just like with possibility number two, we conclude that this is definitely not the case.

The fourth possibility is given by Tsongkhapa's analogy that a chariot does not "rest in its parts, like Devadatta in a tent" (TSONGKHAPA, 2002, p. 279). In that case, the inherently existing parts of the chariot would be the basis on which the inherently existing chariot would depend. The 
inherently existing chariot would exist within the inherently existing parts, like a person sitting inside a tent. The same problem arises here as in the previous case, that is, the relationship of dependence between inherently existing things can only be conceived if those things are totally separate entities. Therefore, Tsongkhapa concludes: “...such relationships could be demonstrated only if a chariot and its parts were essentially separate, but they are not. Here we do not refute mere mutual existence [conventional existence]; we refute a basis and dependent that exist by way of intrinsic character."(TSONGKHAPA, 2002, p. 279).

The fifth possibility analyzes the relationship of possession. Generally speaking, we use the notion of possession in two senses: possession between two different entities, like a person who has a computer for example, and possession between entities which are not substantially separate, like the computer having a keyboard. Tsongkhapa illustrates those two cases using the analogy of Devadatta possessing oxen, that is, "objects other than himself", and Devadatta possessing his own ear. Regarding the relationship of possession between different entities, the answer is the same as given in the cases above, that is, for a chariot to possess its parts in such a way, "a chariot and its parts should likewise be seen separately, yet they are not." (TSONGKHAPA, 2002, p. 279). As G. Sopa states it, being inherently separate entities means "being different [or separate] from the side of the object, in which case such things would be totally unrelated." (SOPA, 2017, p. 428 ) On the other hand, if we defend that the inherently existing chariot possesses its inherently existing parts as a person possesses its ear, that is, as being both the same entity, we fall in the same situation as explained in the first possibility: the inherently existing chariot would have to be identical to its inherently existing parts, which was the first possibility refuted by the analysis. Being inherently the same entity, or identical, means being one inherent identity from the side of the object, which signifies that it would not be possible to distinguish between different 'identities' inherently composing one identity, or nature, that exists inherently in the object.

Conventionally, of course we can say that I possess my hands and the chariot possesses its parts, and those sentences have an understandable meaning. However, if we try to conceive that each of those names - 'I', 'hands', 'chariot', 'parts', 'possess' etc - do correspond to separate natures, or identities, from the side of the objects of cognition, then we fall in all those contradictions pointed out by the analysis. As G. Sopa elaborates it, “... the main target of refutation is the belief that the objective referent of a name can be found when it is sought". (SOPA, 2017, p. 430) Therefore, Tsongkhapa repeats: “Again, we do not refute the conventional existence of Devadatta's merely having an ear, and the same applies to the chariot. Thus we refute intrinsically characterized possession." (TSONGKHAPA, 2002, p. 280)

The sixth possibility analyzes the proposition that the chariot is the mere collection of its 
parts. The target of the sixth and seventh parts of the analysis are the realist schools, like the one represented by Dharmakīrti. Tsongkhapa refutes the sixth possibility saying that, if the chariot were the mere collection of its parts, then we would have to find a chariot existing in the mere collection of separated parts "lying in pieces" randomly. Also, addressing those who state that the chariot is the mere collection of its parts because the name/concept 'chariot' is imputed on this collection of parts, Tsongkhapa answers that the chariot cannot BE the mere collection of its parts exactly because this collection of parts is the basis of imputation of the chariot. The basis of imputation and the concept/name imputed cannot BE the same thing. We must remind ourselves here that the imputation of concept/names is done by a cognitive event and therefore can change according to circumstances or to different ways of phenomena's functioning. As explained in footnote 38 in Part Two, according to Dharmakirti's epistemology (which is the epistemology adopted by Tsongkhapa with the ontological difference that, for Tsongkhapa, the basis of attribution of concept/names are not composed ultimately of substantially existent partless particles), the properties that constitute the nature of phenomena are approached as properties that appear as so to a specific cognitive event and are thus dependent on mental states such as need, habituation, expectation, purpose etc. Therefore, when we cognizes a phenomenon whatsoever, thus subsuming our sensitive data to a categorical type or universal, we do so always with an objective in mind, aiming at some activity. Besides, the categorization is also done always within the context of a specific relationship (based on functions or types of behavior) between the 'cognizer' and the 'cognized'. For example, the same person may be cognized and categorized as 'mother' by her sons or daughters and, at the same time, as 'teacher' by her students. Therefore, there is no sense in saying that the basis of imputation and the concept/name imputed are the same thing. Speaking of the relationship between the collection of the aggregates and the self that is imputed on it, Tsongkhapa says: “... since the collection of the aggregates is the basis to which the self is imputed, it cannot be the self." (TSONGKHAPA, 2002, p. 280)

The seventh possibility discusses the conception that the chariot is the specific arrangement of its parts in a particular shape. Tsongkhapa replies that there are only two possibilities to conceive the shape of the chariot: either it is the shapes of its parts or the shape of the collection of parts. Let us examine the first proposition. If the shape of the chariot is the shapes of its parts, again there are only two possibilities to conceive that. Either we are referring to the shapes of the parts as being the same shapes before they are assembled and after they are assembled, or we refer to different shapes, that is, we conceive that the shapes of the parts before they are arranged are different from the shapes after they are put together. If we say that the shapes are the same before and after being assembled, then says Tsongkhapa, in the same way as there is no chariot when the parts are randomly lying in pieces, that is, not arranged, there must also be no chariot when the parts are put 
together, since the shapes of the parts have not changed: “... the shapes of the wheel and such have no features after assembly unlike those they had prior to assembly. Therefore, just as there is no chariot when the parts are separate, there is no chariot when they are assembled." (TSONGKHAPA, 2002, p. 281). On the other hand, if the opponent says that the shapes of the parts have changed, Tsongkhapa answers that in case there were some change in the shapes, this should be noticeable. However, a serious examination of the shapes of the parts before and after assembly shows that they have not changed at all.

Finally, the last argument used by the opponent (the realist schools) is to state that the chariot is the shape of the collection of the parts, and not the shape of the parts. To this assertion Tsongkhapa answers saying that the proponents of the realist tenets themselves affirm, as we have seen in Part Two, that collections are only imputations, that is, they do not exist substantially. Therefore, says Tsongkhapa, "it is untenable to impute shape to a collection", since you yourselves (the realist schools) affirm that collections do not exist IN the objects of cognition, but are rather imputed on specific bases of attribution through the subjective cognitive event. Hence, since also the realists admit that collections are nominal-conceptual phenomena, they must also admit that they cannot have an inherently existing shape that could be considered as the objective referent of an inherently existing chariot.

Tsongkhapa ends up the discussion stating that, in his system, different from the realist schools, not only the collections (in the sense of 'identities', 'selves' or 'natures) are simply nominalconceptual phenomena, but also the bases of imputation are not considered as inherently existent either. As mentioned previously, for Tsongkhapa, the realist assumption of the existence of minute partless particles (atoms) as the substratum of the cognitive designations to collections (in the sense of 'identities', 'selves' or 'natures) is simply an 'imaginary construct'. Therefore, although the shape of the chariot can be considered as a basis of imputation to which the nominal phenomenon 'chariot', that is, the imputedly existent phenomenon 'chariot', is imputed, it is not reasonable to affirm that this shape IS the inherently existent chariot, or the objective referent of the nominal phenomenon.

At this point, it is important to observe that, although in Tsongkhapa's system there is no conception of inherently existent basis of attribution of the conceptual-nominal phenomena, this does not mean that the conceptual-nominal imputations are done arbitrarily, randomly, without respecting any criteria whatsoever, as if there were no ontological difference between conceptualizing-naming a cat as a chair or a computer as a mountain. Opposite to that, Tsongkhapa 's strong affirmation that the validity of the 'valid cognitions' remains as valid as ever (despite the fact that his system does not appeal to 'imaginary constructs' such as the notion of partless particles 
posited as a substantially existent substratum for the imputations), according to him, stands on a very solid ground. His affirmation that this validity remains valid has its foundation on our direct experience of the functionality of phenomena. For Tsongkhapa this is the ONLY solid ontological ground for correct and valid imputations. The functionality of phenomena is an empirical ground which is definitely solid enough to guarantee the validity of the imputations, after all, this validity refers to the behavior of phenomena in our relationship with them and to nothing else. And there is nothing else it should refer to. The imaginary constructs fabricated by us (like the partless particles, divine creator etc.) in order to refer phenomena, the mere appearances, to other 'levels' supposedly beyond the sphere of our cognition of them are only symptoms of our innate tendency to grasp at phenomena, holding onto them, and specially to our own selves, as if we and everything else were permanent and concrete. When a practitioner, using correctly the vipaśyana meditation, is able to destroy totally his or her tendency to grasp phenomena in this way, he or she sees that there is no need whatsoever to posit a concrete, solid inherently existent basis to phenomena in order to sustain their interdependent functioning, but that, contrary to that, the mere interdependent functioning of phenomena, their dependent origination, is the only solid basis to account for the ongoing, eternal transformation of every thing.

In 'Song of the Profound View'150, Geshe Rabten specifies the three criteria used to determine whether a basis of imputation is suitable or not: "Something endowed with these three characteristics can be called the basis of imputation of a phenomenon: at times of no examination, a condition for seeing the phenomenon; [at times of no examination] a condition for seeing the functioning of the phenomenon; at times of examination, a condition for seeing thatness (which is synonym of reality or emptiness) ${ }^{151}$." (RABTEN, G. 1989, p. 37)

Tsongkhapa concludes the analysis of the chariot stating that, since the chariot does not exist in any of the seven ways explained above, it cannot be considered as having an inherent existence or inherent nature. If it did exist IN itself and BY itself inherently in such a way, it would certainly have been found by the analysis that seeks for the ultimate existence of phenomena. And exactly as it is with the chariot and its parts, it is also with the ' $\mathrm{I}$ ' and the aggregates.

This vipaśyanā analysis is supposed to be done repeatedly, conjoined with perfected concentration, until one develops full ascertainment, full recognition, that the chariot is construed by one's own cognizing consciousness. After this level has been attained, one also realizes that, despite the fact that the chariot is being projected by one's own consciousness, like in a dream, one has no power to make this conventional chariot disappear. In other words, despite the fact that the 
chariot has been proven to be a mental construction, and one has also deeply realized this in one's own perceptual experience, one realizes at the same time that one does not have control over this appearance. Being posited, projected or construed by the consciousness does not mean here - at all - being posited, projected or construed at will. Therefore, along with the realization that the chariot has no existence in itself, one also understands that its appearance in one's mental continuum is the result of the dependent origination of phenomena, that is, causes have been created, conditions have manifested, and now the result has arisen. One sees then clearly that emptiness [of inherent existence] is 'the other side of the leaf' of dependent origination.

Dependent origination is also understood as karma, in Tibetan las, which means literally 'action'. The concept of las - action - in Tibetan Buddhism is broader than the meaning of 'action' in English. It encompasses not only actions done with one's body but also actions of speech (verbal actions) and mental actions. Mental actions include thoughts, feelings etc, all 'mental movements' or 'mental activities'. All those actions, movements or activities are constantly construing phenomena in the vast universal net of dependent origination. Hence realizing emptiness, for Tsongkhapa, also means establishing the most solid foundation for one's ethical behavior, since truly seeing emptiness is the same as understanding one's crucial role as the architect of one's universe.

As mentioned before, the analysis of the chariot is just a preliminary phase. The same seven point reasoning is supposed to be applied later to one's misconception of one's own person as constituting an inherently existent self, or 'I'. As this realization is attained, the result that it is expected to bring along with it, that is, the gradual dissolution of attachment and aversion, as well as the dissolution of the deeply ingrained mental movements of self-grasping and self-centeredness, must also take place. Again here the practitioner should experience the truth of causality as dependent origination. When the root cause of all the sufferings is seen, touched and destroyed, the whole chain of phenomena that arise in dependent connection with that must also fall way.

The perception of the conventional phenomenon (the chariot or one's own 'I', for instance) which, as a result of repeated meditation analyzing it, is then finally realized as not existing in itself but as being construed in one's mental continuum, constitutes from now on a new type of apprehension of phenomena that Tsongkhapa calls "an apprehension of the existence of things as merely illusory" (TSONGKHAPA, 2002, p. 301). This expression has a very precise meaning. Tsongkhapa explains that conventional phenomena start to arise in one's perception as 'illusory' as a result of a combination of two types of awareness: "one that apprehends an appearance and one that ascertains [its] emptiness [or selflessness]" TSONGKHAPA, 2002, p. 300). In other words, it is the combination of 1) an awareness that apprehends some conventional phenomenon as being inherently existent and 2) an awareness that is the result of the rational analysis applied to this 
phenomenon, ascertaining that, since it does not exist inherently, it is appearing in a way which is different from the mode in which it actually exists. Therefore, 'illusory' here means existing in one way but appearing in another way. The 'illusory-like' perception of oneself and other phenomena is attained as a result of long dedication to the practice of the union of śamatha (perfected concentration) and vipaśyanā as it has been explained here.

"All phenomena are like dreams, illusions, bubbles, shadows, They are like dew, like a lightning... Thus should we contemplate them."

(Diamond Sutra) $)^{152}$ 


\section{Conclusion}

As stated in the introduction to this thesis, Tsongkhapa's text is actually meant to be used as a transmission of a set of instructions for a meditative exercise which, through the use of precise techniques, is supposed to lead the practitioner to generate in his or her mental continuum a particular 'philosophical view'. The expression 'philosophical view' refers here to a conceptual 'view of reality', or a conceptual view of the mode of existence, or establishment, of phenomena. There are other philosophical views which, according to Tsongkhapa, were also taught by the Buddha, like the view propounded by the realist schools with which he debates. If the realist conceptual representation of reality was also taught by the Buddha, this means that, for Tsongkhapa, it definitely does also capture and convey important aspects of reality that must be dealt with in the course of a genuine Buddhist practice. Therefore, it certainly has its value and its crucial role in the development of one's mental continuum.

Considered from this perspective, Tsongkhapa's arguments against the philosophical realist view display their true function in his system. Their function is not to defeat opponents, if we consider the word 'opponent' to refer exclusively to other Buddhist practitioners who adhere to other Buddhist systems of tenets. Actually, Tsongkhapa's arguments have as their main target the practice of those who, having decided to follow the Buddhist path according to his guidance, must at one point refine in their own mental continuum their own realist conceptual representation of reality, which, despite being very useful for many purposes, including for Buddhist practices of specific levels, must be abandoned, or rather, transformed into the subtlest and most precise conceptual representation of reality, or 'philosophical' view, which, due to its utmost conceptual precision, can be eventually converted - during the process of meditation - into the non-conceptual (that is, non-representational) direct perception of reality, or 'thatness'. Therefore, the main 'opponent' to be 'defeated', or 'conquered', by means of the deep reflection and pondering about 
the arguments presented in the text lies in fact within the readers's own mental continuum.

Similarly, the nihilistic view described by him, that is, the view that denies the very existence of objects of cognition, although, according to him, it has never been taught by the Buddha nor is found in any of the authentic Indian philosophical schools, is nevertheless a view that a practitioner may naturally generate when he or she applies the rational analysis and does not attempt to unite his or her view of emptiness thus elicited with the very crucial core teaching about the dependent origination of phenomena. Indeed, when Tsongkhapa describes how those views are generated, he says that when a meditator attains some realization of the emptiness of [inherent] nature through the use of the rational analysis, seeing thus that the identity, or self, of phenomena is construed by the cognitive event, then he or she is not able to see phenomena as existing nor as functioning in the cause-effect relations, but rather, tends to see the emptiness as if phenomena simply did not exist nor could truly fulfill their functioning.

Therefore, here again, the so-called main 'opponent' lies within the reader's own mind. There have also certainly been systematizations which have propounded such views in treatises, teachings and so forth. However, Tsongkhapa's text, as a set of instructions for meditation, does not have those types of systematizations as its principal target, for the real target of an instruction for meditation can be no other than the hearers' (or readers') own mental positions, mental attitudes or views. That means, it is supposed to be used in such a way by those who have decided to take him, or his instructions, as their personal guide in their journey towards full awakening and have set forth in this direction. It is not supposed to be used in order to attempt to defeat or destroy the philosophical view or the practice of those who have decided to take a different guide in their path.

And for those 'opponents' who dwell in the readers own mental continuum, we have concluded that, the chapters of Tsongkhapa's text which have been thoroughly analyzed in this thesis seem to provide three main lines of arguments to be reflected upon. They are:

\section{1 - Arguments to convince the reader of the necessity of uniting emptiness and causality in one sole conception.}

These are arguments aimed at convincing the reader that the view of emptiness must definitely not negate the existence of objects of perceptual cognition, for this implies also the negation of the truth of the causal relations that produce phenomena, which contradicts directly, 
first of all, the very fundamental teachings of the Buddha that are accepted by all schools, namely, the Four Truths. Contradicting the Four Truths means contradicting the very foundation upon which the whole Buddhist practice is supposed to be edified. Secondly, such a mistaken view, which Tsongkhapa calls 'nihilist', also contradicts in a very evident way the practices of the Bodhisattvayāna, or Mahāyāna, taught in the Prajñāpāramitā Sūtras, according to which a Bodhisattva should combine activities to benefit sentient beings in various ways (and eventually guide them to the final state of cessation of all suffering) with a deep realization of emptiness (selflessness) of persons and phenomena. For if the mind of such a practitioner conceives the emptiness of phenomena in such a way that it negates the very existence of the objects of cognition and their production (or causal relations), he or she will not be able to engage properly in those various Bodhisattva activities which are based on the view of dependent (causal) production of phenomena, that is, in the production of real benefit for sentient beings. Therefore, the right understanding of emptiness must necessarily leave untouched and absolutely valid the truth of the causal production of phenomena.

\section{2 - Arguments to convince the reader of the possibility of uniting emptiness and causality in}

one sole conception. This set of arguments can be further sub-classified in:

$2 \mathrm{a}$ - Arguments to demonstrate that the conception of the impossibility of uniting emptiness of a nature and dependent origination arises due to the lack of proper fine distinctions. They are:

$2 \mathrm{a}^{\prime}$ - the lack of the distinction between a nature in the object of cognition and the nonexistence of the object of cognition itself;

$2 \mathrm{a}$ " - the lack of the distinction between the existence ( $\operatorname{ood} \mathrm{pa}$ ) of the object of cognition and the establishment of the object of cognition by its own entity (rang gy ngo bo kyis grub pa);

$2 \mathrm{a}$ ", - the lack of the distinction between establishment by one's own entity (rang gy ngo bo kyis grub pa) and mere (tsam) establishment - This last distinction can be also expressed in two other different ways: distinction between 'existence by one's own entity '( rang gi ngo bos yod pa)' and 'mere existence (tsam yod pa)'; and distinction between 'one's own nature' and ' mere nature'.

$2 \mathrm{~A}$ ",' - the lack of distinction between 'not resisting the rational analysis' and 'being destroyed by the rational analysis'. According to Tsongkhapa, concluding that the rational analysis can destroy the existence of phenomena is actually a case of misusing the analysis, since, for him, such procedure does not in the least empower the meditator to negate the existence of an object of analysis that is indisputably appearing to him or her as a perceptual cognition and which functions in some way, that is, which produces results. 
$2 \mathrm{~b}$ - Uniting emptiness with the grossest level of dependent origination, that is, with dependence on causes and conditions. In order to clarify this topic, we used the example given in Pabongks Rinpoche's book 'Liberation in our Hands ${ }^{\text {, }}{ }^{153}$, and we repeat it here: if a sprout possessed its nature of 'sprout' in itself, inherently, such a nature could not have been produced through the action of various causes and conditions. These causes and conditions are, for instances, the fact that a seed has been planted in a fertile soil, and after that, has been exposed to specific conditions, like the correct amount of watering, heat etc. It is precisely because such a sprout does not possess its nature inherently that we can admit that it was originated as an effect of those various causes and conditions. It is also this quality of being empty of an inherent nature that allows the sprout to gradually change into a mature plant, produce grains etc. Therefore, it is exactly because the sprout does not possess its nature inherently that we can see the cause and effect relation truly functioning as well as the transformation of phenomena as truly effective. Regarding this point, Tsongkhapa affirms that the dependent origination of phenomena is actually "the best reason" we can use to establish the truth of the absence - or emptiness - of inherent nature (TSONGKHAPA, 2002, p. 137)

$2 \mathrm{c}-$ Adding to this union the deepest level of dependent origination, which is the emptiness of inherent existence, or inherent nature, in the sense that phenomena are constituted in the cognitive event. Here Tsongkhapa faces the challenge of demonstrating that the conception of phenomena as being construed in the cognitive event does not invalidate their functionality. The argument used to support this point is the fine distinction between the epistemological domain and the ontological investigation. Here he performs a sort of dissociation between the epistemological validity of a cognition, on one hand, and, on the other hand, the implicit ontological assertion which, according to him, some philosophical systems - or certain mental positions - 'add', or attach, to the epistemological validity. Tsongkhapa asserts that it is not correct to simply superimpose to the ordinary notion of epistemological validity - which refers specifically to the adequacy of a certain name and concept to a certain cognition due to its correspondence to a given type of functionality -, it is not correct to superimpose on this kind of epistemological validity the attached belief or assertion that this validity necessarily implies the ontological fact of such an object of cognition being established, or exist, by its own entity, or with its characteristics belonging to it inherently or essentially. In other words, according to Tsongkhapa, epistemological validity must be 
circumscribed only to the sphere of the object of cognition's correspondence to specific types of functionality. In this sense, epistemological validity must not be used as a means of asserting anything regarding the object's mode of existence. He establishes here a clear border between those two domains.

His main argument to establish this border is the idea that conventional valid cognitions, like 'this is a table', 'that is a computer' etc, belong to the field of pragmatical cognitions and, as such, do not even raise the question regarding the ultimate mode of existence of their objects. Their purpose is a totally different one, it is simply the intention of utilizing such objects for pragmatical activities. Therefore, since they are cognitions which do not even raise the question of the ultimate mode of existence of their objects, they obviously also do not have any 'authority' to provide any type of answers in relation with this point. Nonetheless, they do come up with answers about that! That means, they always come accompanied by this 'added ontological belief' that their objects exist by themselves, in themselves, totally independent of the cognitive event. Should we give credit to this attached ontological view present in our daily valid cognitions? Tsongkhapa's answer is that we should definitely not give any credit to such added ontological view, for this added ontological belief is precisely our fundamental delusion - marigpa -, it is precisely the very object that must be negated in the vipaśyana (lhag mthong) meditation.

However, Tsongkhapa still must answer the following question: does the dissolution of this attached ontological view cause any real loss to the epistemological validity of valid cognitions? According to him, this definitely does not occur, for such conventional valid cognitions are not in the least established by the dimension of the ontological question about their mode of existence. They are established by another order of phenomena, that is, they are established as appearances to us by causes and conditions and, in this sense, they are already there established long before the ontological question has even been raised. Therefore, since they are not established by the ontological question, the ontological question cannot also destitute them of the fact that they are established for us. That means, neither the presence of the attached ontological belief that such appearances exist by themselves and in themselves nor the absence of such an attached view make absolutely any difference whatsoever regarding the indisputable fact that they are established for us as functioning appearances here and now. Actually, for Tsongkhapa, the proper ontological question cannot even intend to deprive any phenomenon of the fact that it is established here and now as a functioning appearance. The ontological question can simply ask about the mode of such an establishment, about the mode of this existence, that is, about how this phenomenon has been established as an object of cognition for me here and now. And the answer has already been given 
by the Buddha: phenomena are established by dependent origination. Causes have been created, conditions have manifested and so the appearance has arisen.

This subtle distinction between the epistemological validity and the ontological issue appears clearly in the differentiation that the Gelug makes between the 'held object' and the 'basic object'. As mentioned before, G. Sopa explains that we add the 'inherent nature', or 'inherent existence', to the basic object, which is the mere phenomenon, that which appears to us. We create thus the 'held object' as, for example, a computer with its inherent nature as a computer, that is, a computer that exists as such by itself and in itself, or, in other words, an inherently existent computer. (SOPA, 2017, p. 288) Therefore, instead of grasping the conventional object of cognition as a dependently originated mere (functioning) appearance, we grasp it mistakenly as if it did exist, or were established, on its own side, by itself, with its own identity just there 'waiting' to be apprehended by us.

Regarding the Buddhist notion of dependent-origination, as we have seen, Tsongkhapa points out the existence of three levels of dependence: dependence on causes and conditions, dependence on the parts and dependence on the subjective conceptual designation. From the Gelug perspective, Tsongkhapa is not adding his own personal ideas to the teachings of the Buddha. Rather, he is integrating the different sets of teachings, demonstrating consistency between them instead of contradiction. Thus, the teachings on the Four Truths, which are said to constitute the first turning of the wheel of the Dharma, and which explain the origin of phenomena in terms of causality, are combined with the teachings of the second turning of the wheel - found in the Prajñāpāramitā Sütras -, which explain the emptiness of phenomena, that is, the fact that they do not have 'inherent characteristics', or, in Tsongkhapa's terms, they do not have an inherent nature, an inherent existence, or still, they are not established by their own entity.

We can say perhaps that, from Tsongkhapa's perspective, he sort of 'unfolds' the notion of dependent origination in its different levels which are actually taught in the distinct set of teachings of the Buddha and also explained in the treatises by Nāgārjuna and Candrakīrti. In this sense, emptiness, understood as 'emptiness of inherent nature' - or emptiness of own being or inherent identity, that is, emptiness understood as the fact that phenomena's nature, or identity, is construed in the cognitive event - is conceived as indicating one more aspect of the dependent origination of phenomena, that is, the aspect that phenomena depend on the subjective categorization to be established. As intrinsically connected to the dependent origination of phenomena, emptiness is also intrinsically connected to causality, which is the grossest level of dependence. The notion of 
dependent origination, clearly broader than the mere cause-effect relationship, encompasses causality - as we ordinarily conceive it - through defining it as one of its layers, leaving thus open the door for the intrinsic connection between emptiness and causality to be accomplished in one's view of reality. Therefore, it is by means of the explanation of emptiness as dependence on the subjective cognition that Tsongkhapa unites emptiness and dependent origination in one sole view, including in it also our gross, ordinary, conception of causality.

Moreover, for Tsongkhapa, this union of dependent-origination and emptiness, as well as the assertion that emptiness is the most fundamental level of dependence, where we also find the deepest root of the misconception of reality, does not bring any discredit to the validity of the functioning of phenomena, since this functioning is directly experienced, not only in our ordinary daily level of cognition of phenomena but also in the subtlest level of direct perception of reality, when fully awakened beings (that is, Buddhas) directly see all levels of dependent origination of phenomena in indissoluble union with their emptiness.

The main argument used by Tsongkhapa to state that the ignorance of the dependence on causes and conditions and of the dependence on the parts corresponds only to the grossest levels of a falsely construed self projected onto phenomena is the fact that, according to him, when one meditates on selflessness using only these lines of reasonings, that is, reasons that demonstrate that phenomena do depend on causes and conditions and on their parts, although one attains thus the important realization that antidotes the misconceptions of phenomena as being independent, permanent (not caused) and unitary (partless), one does not yet, through such a meditation, touch the root innate mistaken conception. And how does one know that? Simply because, meditation on those types of more superficial selflessness does not have any effect to decrease the mental afflictions. Therefore, such misconceptions cannot be the innate root marigpa. The criterion, as we can see it, is empirical. One must put such meditations into practice and check whether or not they show real effects regarding the dissolution of the mental afflictions. It is clearly the approach of an accomplished meditator who is transmitting instructions to those willing to follow his steps. It is almost as if he were saying: 'I have put those meditations into practice but the root of attachment and aversion was not touched by them, whereas when I meditated on selflessness as dependence on the cognition and united this with dependent origination with all its layers, then, yes, the mental afflictions started to decrease. Therefore, those who want to follow my instructions must try and do the same, and they will see by themselves'.

It is from this perspective that Tsongkhapa states that the idea of an independent, permanent 
and unitary self is a philosophically acquired misconception, and not an innate view. G. Sopa explains it:

...most people do not hold themselves to be a permanent, partless and independent self. They think of themselves in a more simple way, without any such analysis. (...) ...the main target is innate ignorance, which dominates the ordinary mental activity of living beings in daily life. (SOPA, 2017, p. 241)

And Gonsar Rinpoche says:

When we come to that point, which is Sūnyatā (emptiness of inherent existence), we reach the subtlest view. But it is not easy for everybody to immediately come to that point. So Buddha very skillfully also taught other levels of selflessness. First of all, negating a self which is philosophically postulated, a permanent soul which is independent, unitary etc. There are many who believe in such kind of a soul, which is also a grasping to some kind of false self. But this is very gross, it is a philosophical error. And there are still others which are subtler than that. But this subtlest kind of selflessness is not a philosophical error, it is a natural fabrication, (a natural) grasping, of our mind ${ }^{154}$.

\section{3 - Arguments to demonstrate that it is actually impossible for us to rationally conceive that phenomena exist in themselves and by themselves, independently of the cognitive event.}

Those are the arguments found in the application of the sevenfold rational analysis as explained in the section that analyzes the chariot. The conclusion one is supposed to reach as a result of the proper practice of such a meditative exercise is, indeed, that the identity/self of the chariot is imputed by the cognitive event, since it cannot be conceived in any of the seven ways as existing in the object of cognition itself. 
After having understood correctly the main arguments provided by the text and properly reflected about them, the meditator should now attempt to generate in one's own mental continuum the view that unites dependent-origination and emptiness of inherent existence as non-contradictory, that is, as two sides of the same leaf. The arguments classified here as those that address (1) the necessity of combining emptiness and causality and (2) those which address the possibility of accomplishing such a union seem to be a sort of 'prerequisite training', so to speak, in order for the practitioner to be prepared for the vipaśyanā sevenfold analysis meditation. That means, the pondering about those lines of reasonings is supposed to lead the meditator to avoid taking naively the conclusion of the sevenfold rational analysis - that is, that the chariot and/or the personal self do not have a nature in themselves, that they do not exist by themselves - as meaning that those phenomena simply do not exist.

Instead, the practitioner is led to pursue the meditation further until he or she eventually reaches the correct view of emptiness, that is, the view that sees emptiness and dependent origination as united in reality. As Tsongkhapa described in the text, the apparent opposition between emptiness and dependent origination must be gradually surmounted until eventually the two views get combined in one sole conception. When those two understandings - the dependent origination of phenomena and their emptiness of [inherent] nature - cease to take place separately in one's mental contimuum and, opposite to that, start to come together, without alternating, then one can consider that his or her vipaśyana practice has completed the Madhyamaka analysis. In Tsongkhapa's words:

When they come together [emptiness of inherent nature and dependent origination], no longer alternating,

Just seeing dependent origination in a non erroneous way

Destroys how the object is grasped by wrong apprehension,

Then one's analysis of the view is complete. (Lam gtso nam gsum $)^{155}$

155 Our translation. 
"The world is empty (suñña) of a self or of anything pertainning to a self." (Samyutta Nikāya, Salayatana Vagga, Suñña Sutta) ${ }^{156}$

As stated at the end of Part Two, our analysis of Tsongkhapa's treatise The Great Exposition of the Stages of the Path (Byang chub lam rim che pa), Part Two; Insight was guided by the following question: since the Madhyamaka view denies not only the atomistic ontology present in Dharmakīti's writings, but also the very existence of natures (svabhāva, rang zhin) of phenomena, a concept upon which Dharmakīrti's explanation of inferential knowledge is based, how does Tsongkhapa combine his presentation of selflessness with Dharmakīrti's epistemology without generating internal contradictions in his system?

First of all, it is necessary to remind our reader here that we are speaking of Dharmakīrti's epistemology according to the way that the Gelug manuals present it, that is, according to the lineage of interpretation that was founded by Tsongkhapa himself, and which is considered to have as its ultimate textual source, as mentioned, Tsongkhapa's own interpretation of Dharmakīrti's philosophy. Nevertheless, in spite of our reference being Tsongkhapa's own interpretation of Dharmakīti's philosophy, there are still relevant issues that must be addressed, since we are dealing with two different systems that definitely present different ontological assumptions.

Let us briefly re-articulate here the main point of a potential contradiction. Since Tsongkhapa elaborates his presentation of selflessness as a Madhyamaka view, that is, as a view 
that necessarily negates the existence of the 'natures' (svabhāva, rang zhin) of phenomena, how can he use inferences in his way of propounding this Madhyamaka view, as inferences are based on the conception that certain linguistic phenomena are 'one [same] nature', like 'impermanence' and 'produced'?

The model of rational analysis applied by Tsongkhapa to the chariot and to the personal self does not use reasonings with the same structure as presented in Part Two with the example 'sound is impermanent because of being produced ${ }^{157}$. Nevertheless, the consequential model used by him in his application of the rational analysis is also based on the same ontological principle explained in Part Two, namely, that language and concepts express in a trustworthy way certain patterns regarding the mode of existence of things. Besides, when presenting arguments against those who refute causality along with the nature of phenomena, Tsongkhapa actually speaks of the union between dependent origination and selflessness using the logical notion of pervasion, also explained in Part Two, and which is grounded on the above mentioned ontological assumption that some phenomena are of 'one same nature'. He says:

Therefore, [Nāgārjuna] speaks very clearly about the pervasion that whatever depends on causes and conditions lacks [inherent] nature and the reversed pervasion that whatever has [inherent] nature does not depend on causes and conditions." (TSONGKHAPA, Byang chub lam rim che pa, p. 589)

In other words, exactly as 'impermanence' and 'being produced' are of 'one [same] nature', also 'depending on causes and conditions' and 'lacking inherent nature' are of 'one [same] nature'. Therefore, Tsongkhapa's presentation of the Madhyamaka view of selflessness definitely works with the notion of the existence of 'natures' as a fundamental concept. Is it not contradictory to use an epistemological background according to which the 'natures' involved in the inferences do correspond to valid patterns of ontological characteristics in order to, finally, negate the existence of these very 'natures'?

In fact Tsongkhapa does not consider that his presentation negates the 'natures' that are responsible for the efficiency of the inferences. As we have seen, his explanation of selflessness opens up a new dimension in the concept of nature, a dimension which was not taken into consideration during the preliminary discussion about how 'valid cognitions' are formed. We can say that, in Tsongkhapa's Madhyamaka treatise, the notion of 'nature' unfolds into two: the 'inherent 
nature' and the 'mere nature', both of which are supposed to be found in meditative introspection, then separated from each other, so as only the mistaken one, the 'inherent nature', may be the object of the rational analysis that should recognize its deceiving character and thus dissolve it.

Therefore, according to him, we should be left with the 'mere nature' as a sufficient foundation for causality, thus granting the efficiency of phenomena and serving as a solid ground for the generation of inferential knowledge. And the 'mere nature' is the one that is characterized by the fact that it is not supposed by us to be, at any level whatsoever, a nature, or self, which is so in itself, that is, a nature, or self, which is what it is by the power of its own entity. In other words, this nature, self or identity, is not established by itself. It is 'merely' established, that is, it is 'merely' established to us as a cognition without my judgment about how it has been established.

When we consider that something has a nature in itself, or exists in itself, says Tsongkhapa, we are actually unconsciously adding to this 'cognitive presence' a judgment regarding how this 'cognitive presence' has been established to us: it has been established to us caused by an objective nature that exists as so in itself and which serves as the cause or condition for my 'perceptual mirroring' it in this or that way. Our ordinary way of cognizing phenomena contains this 'additional' ontological judgment, according to Tsongkhapa's view. And this is what must be cleared away. Therefore, we should keep just this 'mere nature', or 'mere establishment' or 'mere existence' of the appearances, or phenomena. However, at this point, the following question may be raised: can these 'mere natures', that is, those natures merely established as appearances to us, can they sustain the notion of the correspondence of the logos and the being, sustain the notion that they do correspond to ontological patterns of beings, so as to guarantee the efficiency of phenomena in general and of the inferential reasoning in particular?

Raising this question, we find ourselves exactly in the position of the 'realist opponents', mentioned so many times in Tsongkhapa's exposition. As this kind of doubt arises in us, we discover that our mind is now in the extreme of the eternalism, a situation in which we still find it so difficult to understand, or even to conceive, that 'mere appearances' can have functionality, that 'mere appearances' can manifest patterns of behavior or patterns of modes of existence trustworthy enough to sustain the functionality of ourselves and all around us.

It is time now to go back to Tsongkhapa's exposition and try to reflect about the arguments used by him against the realists. What does he say? He says that conceiving appearances as having inherent natures, or inherent existence, is the same as conceiving them as having NOT been 
generated interdependently. It means to conceive them as existing in themselves and by themselves, which is the direct opposite of conceiving them as being dependently originated. So let us now imagine that, after applying correctly the rational analysis to the chariot, we attain this view of the chariot as a mere appearance, totally free from the misconception that this appearance is being caused by an inherently existing chariot, a chariot that would exist as such, as this identity, totally independently from this present cognitive event. After that, we apply the same analysis to our own selves ('I'), and again attain this view of the 'I' as a mere appearance. Let us also imagine that, at this moment, we remember Tsongkhapa's explanation that emptiness is 'one same nature' with dependent origination, which means, in this situation, that this appearance of the 'I' now (as the appearance of the chariot just moments ago) - as empty of being established by its own entity - must have been generated by causes and conditions. Indeed, despite the fact that we realize now that this appearance of the mere ' $\mathrm{I}$ ' (as the appearance of the mere chariot) is being construed by this present cognitive event, we also realize that we have no control of it, we cannot simply make it disappear. This must signify that the present cognition construing it is not the ONLY causal factor. It must have been produced also by the power of other causes and conditions forming, as explained before, a vast and deep chain of causation. Such causes and conditions, however, from now on, should not be conceived anymore as inherently existent natures or identities. And this does not mean that those causes and conditions did not exist, did not function, and thus could not produce this mere 'I' or the mere chariot. It is exactly the opposite: it is BECAUSE they were never inherently existing identities that they could produce these present mere appearances of the 'I' and the chariot. Therefore, what is meant here is that, when our cognition tries to apprehend this continuous productive flow of transformation, our cognition creates identities, sort of separating conventionally this continuous flow in parts, like cause, result, subject, object, mind, body, I, you etc.

Those conventions, however, are not arbitrarily created. On the contrary, they are created on the basis of different functionalities which are experienced as real, in the sense that they do produce specific results characterized by other specific functionalities. And such functionalities are not created by the cognitive event. The cognition creates only the identities, separating this flow in parts, as if different moments, different functionalities, could exist inherently, that is, ultimately ontologically separated - which is not the case. That is why this flow of transformative functionalities sustains the validity of the cognitions, despite the fact that, in the reality of this flow, the diverse functionalities do NEVER really constitute separate identities, inherently existent entities truly and ultimately ontologically separated from each other. It is a continuous flow, a continuum in time and space, so to speak, profound and vast, with no inherent separation of anything. In this continuous impermanent flow of transformation, not even for a millesimal of a 
second, some 'part' of it gets stagnated to the point of generating one inherent permanent nature. However, transformation is occurring, and our ordinary cognition can capture some aspects of the 'mode of these transformations' through the functionalities that we experience directly again and again. For a cognition to be able to cognize directly, though, the subtlest - most profound - level, the one called 'reality' or 'thatness', when one realizes together the transformation, or production, of appearances and the fact that they do not, not even for a second, constitute an inherent permanent nature, one needs to enhance the capacity of one's apprehension of phenomena.

That is why we must bear in mind that the rational analysis is just one phase of the development of the cognitive capacity towards the full awakening. It is the stage when, for the first time, a practitioner recognizes that the identities are construed by the cognitive event. And as the development continues, at one point, the meditator will attain a direct perception - that means, not a conceptual realization, like the one that is obtained through the application of the rational analysis of this 'identitilessness', or selflessness, an experience which is commonly described in this lineage as 'water mixing with water'. Again, this does not mean that causality, transformation, production are being negated. According to Tsongkhapa, The Buddha's mind, that is, a fully awakened mind, is the one that perceives both truths at the same time: the conventional identities and their emptiness of an inherent self. Therefore, causality is definitely one aspect of reality, although, in reality, it does not exist as we cognize it ordinarily now, that is, as an inherently existing cause inherently producing an inherently existing result which is inherently perceived by an inherently existing subject, as if all those phenomena, cause, production, result, perceiving subject, constituted truly ultimately ontologically separated identities.

From the perspective of the meditator who realizes the conventional character of his or her 'I', this flow of functional transformation has two possible directions, depending on the kind of mental movement that he or she chooses to cultivate from now on. If one does not remove the mistaken projection of an 'inherent identity' from one's perception of oneself, thus conceiving oneself as truly ontologically separated from everything else including, most fundamentally, one's own self-cognition, then the self-grasping continues to manifest, and along with it, selfcenteredness, attachment, greed, aversion, hatred etc, then the actions determined by those mental states, all of those soaked in different levels of suffering and generating more and more suffering. On the other hand, if one removes the projected inherent nature of one's perception of oneself, thus realizing that oneself is actually not only impermanent, being continuously generated by countless inner and outer causes and conditions, but also and most fundamentally, one is selfless, that is, this ' $\mathrm{I}$ ' is being construed by the present cognitive event, then the self-grasping does not arise, nor does 
the self-centerdeness, attachment, greed, aversion, hatred etc, nor all the different degrees of suffering that are experienced along with those phenomena.

Ultimately, this means that this union of dependent origination and selflessness is meant to be pursued and experienced directly by oneself individually. The rational argumentation provided by Tsongkhapa in his treatise is meant actually to be used as an instruction for those seeking to see reality as a means to dissolve all suffering. His philosophy does not represent the construction of a sophisticated conceptual network which has the purpose of providing a rational foundation for reality. Different from that, his philosophy is the transmission through words of a non-ordinary experience of perception of phenomena. And according to the very limited way we have been able to understand it so far, we conclude that, in Tsongkhapa's explanation of selflessness as united with dependent origination, that is, with the dependent production of phenomena where causation has an extremely important role, there is no contradiction between, on one side, defining selflessness as the lack of inherent nature, and, on the other side, proving this selflessness through inferences based on the postulate that the mere conventional imputation of phenomena does validly correspond to their functionality. In other words, in this system, the logos can reflect the mode of the mere establishment of transient appearances, the logos can reflect the river of becoming. 


\section{REFERENCES}

TSONGKHAPA, Byang chub lam rim che pa printed and published by the Tibetan Cultural \& religious Publication Centre, Delhi, India;

TSONGKHAPA, The Great Treatise on the Stages of the Path to Enlightenment (Byang chub lam rim che pa); Snow Lion, Ithaca, New York, 2000-2003;

TSONGKHAPA, Ocean of Reasoning, Tradução de Geshe Ngawang Samten e Jay Garfield; Oxford University Press, 2006;

TSONGKHAPA, Tantra in Tibet - The Great Exposition of Secret Mantra, vol. 1, Motilal Banarsidass Editions, Delhi, India, 1987.

TSONGKHAPA - Middle Way Critical Philosophy - Insight Meditation. In: 'The Life and Teachings of Tsongkhapa'. Library of Tibetan Works and Archives, 1982, Dharamsala, India.

TSONGKHAPA, Illumination of the Thought, in HOPKINS, 'Tsongkhapa's Final Exposition of Wisdom'; Snow Lion Publications, New. York, U.S.A., 2008;

DHARMAKIRTI, Pramāṇavārttika, extracts in DUNNE, 'Foundations of Dharmakirti's Philosophy', Sommerville, Wisdom Pulbications, USA, 2004;

DHARMAKIRTI, Pramāṇavārttikasvavrtti, extracts in DUNNE, 'Foundations of Dharmakirti's Philosophy', Sommerville, Wisdom Pulbications, USA, 2004;

DHARMAKIRTI, Nyāyabindu (Drop of Logic), in STCHERBATSKY, Th., 'Buddhist Logic', vol. II, Motilal Banarsidass, Delhi, India, 1999.

(DHARMAKīRTI, Nyāyabindu, (Drop of Logic) in WAYMAN, A., 'A Millenium of Buddhist Logic', Motilal Banarsidass, Delhi, India, 1993.

YONGDZIN PURBUCHOK LOBSANG TSULTRIM JAMPA GYATSO (Yongs 'dzin phur lcog pa blo bzang tshul khrim byams pa rgya mtsho) (1825-1901), Magic Key to the Path of Reasoning: A Presentation of the Compendium of Debates, [Types of] Mind and [Analysis of] 
Reasons that Discloses the Meaning of the Great Scriptures on Vlid Cognition (known as 'Yongdzin Dura') (Tshad ma'i gzhung don 'byed pa 'i bsdus grwa dang blo rtags kyi rnam gzhag rigs lam 'phrul gyi lde mig). In: KHENSUR, Lobsang Tarchin Rinpoche, 'Pointing the Way to Reasoning'. Mahayana Sutra and Tantra Press, New Jersey, U.S.A., 2005.

YONGDZIN PURBUCHOK LOBSANG TSULTRIM JAMPA GYATSO (Yongs 'dzin phur lcog pa blo bzang tshul khrim byams pa rgya mtsho) (1825-1901), Magic Key to the Path of Reasoning: A Presentation of the Compendium of Debates, [Types of] Mind and [Analysis of] Reasons that Discloses the Meaning of the Great Scriptures on Vlid Cognition (known as 'Yongdzin Dura') (Tshad ma'i gzhung don 'byed pa 'i bsdus grwa dang blo rtags kyi rnam gzhag rigs lam 'phrul gyi lde mig). In: PERDUE, D. E., 'Debate in Tibetan Buddhism'. Snow Lion Publications, New York, U.S.A., 1992;

KEDRUP TENPA DARGYE (mKhas grub chen po dge 'dun bstan dar ba) (1493-1568), Analysis of the Perfection of Wisdom (Phar phyin mtha' spyod spyi don) - a commentarial manual used by Sera Mey Monastery -, selections in KHENSUR, Lobsang Tarchin Rinpoche, Pointing the Way to Reasoning, Mahayana Sutra and Tantra Press, New Jersey, U.S.A., 2005;

CHONE LAMA DRAKPA SHEDRUP (Co ne bla ma grags pa bshad sgrub) (1675-1748), Analysis of Reasons, the Essence of Scriptural Authority and Logical Reasoning: a Presentation of Reasoning to Delight Scholars (rTags rigs kyi rnam gzhag lung rigs kyi snying po bsdus pa mkhas pa dgyes byed), selections in KHENSUR, Lobsang Tarchin Rinpoche, Pointing the Way to Reasoning, Mahayana Sutra and Tantra Press, New Jersey, U.S.A., 2005;

DEN DAR HLA RAM BA, Presentation of Specifically and Generally Characterized Phenomena, selections in KLEIN, Anne Carolyn, 1991, Snow Lion Publications, N.Y., USA;

NGA WANG DRA SHI, Positive and Negative Phenomena, in KLEIN, Anne Carolyn, 1991, Snow Lion Publications, N.Y., USA;

JANG GYA ROL BAY DOR JAY, The Sautrāntika Tenet System, from 'Presentation of Tenets', in KLEIN, Anne Carolyn, 1991, Snow Lion Publications, N.Y., USA;

JAM YAM SHAY BA, Great Exposition of Buddhist and Non-Buddhist Views on the Nature of Reality, in HOPKINS, J., Maps of the Profound, 2003, 
GON-CHOK-JIK-MAY-WANG-BO, Precious Garland of Tenets, in SOPA, G.Lhundup; HOPKINS, Jeffrey; 'Cutting Through Appearances', Snow Lion, N.Y., USA, 1989;

JeTSun CHOGYE GYELTSEN, Presentation of Doctrines. In PRESTON, Craig., 'How to Read Classical Tibetan', Snow Lion, Ithaca, New York, 2009;

BECHERT \& GOMBRICHG, Heinz, Richard (ed. by), The World of Buddhism, Thames and Hudson, London, 1991.

DREYFUS, G. B. J., Recognizing Reality: Dharmakirti's Philosophy and its Tibetan Interpretation, State University of New York Press, NY, USA, 1997;

DUNNE, J., Foundations of Dharmakirti's Philosophy, Sommerville, Wisdom Pulbications, USA, 2004;

DUNNE, J.: Dharmakīrti's Apoha-theory of Concept Formation: Some Key Features, (Forthcoming from Columbia U. Press in a volume edited by M. Siderits and T. Tillemans), Emory University;

GOMBRICH, R., The Evolution of the Sangha, in 'The World of Buddhism',' Thames and Hudson, London, 1991.

GONSAR, T. R., Erscheinung und Leerheit: eine Einführung. Edition Rabten, Switzerland, 1999.

HOPKINS, J., Maps of the Profound, Snow Lion Publications, New York, USA., 2003;

HOPKINS, J., Tsongkhapa's Final Exposition of Wisdom; Snow Lion Publications, New. York, U.S.A., 2008;

HOPKINS, J., The Tibetan Genre of Doxography: Structuring a Worldview, in 'Tibetan Literature: Studies in Genre', Snow Lion; USA, 1996, pp. 170-186.

KHENSUR, L. T. R., Pointing the Way to Reasoning, Mahayana Sutra and Tantra Press, New Jersey, USA., 2005; 
KHENSUR, L. T. R., The Logic and Debate Tradition of India, Tibet and Mongolia, Mahayana Sutra and Tantra Press, New Jersey, USA., 1979;

KLEIN, A. C.,: Knowing, Naming and Negation, Snow Lion ed. New York, U.S.A, 1991;

LOPEZ, D. S. Jr.;. The Heart Sutra Explained: Indian and Tibetan Commentaries, State University of New York Press., Albany, USA, 1988;

NEWLAND, G., Debate Manuals (Yig cha) in dGe lugs Monastic Colleges, in 'Tibetan Literature: Studies in Genre', Snow Lion Publications; NY, USA, 1996;

NEWLAND, G., Introduction to Emptiness - as Taught in Tsongkhapa's Great Treatise on the Stages of the Path -, Snow Lion Publications, NY, USA, 2008.

ONODA, S. bsDus grwa Literature, in 'Tibetan Literature: Studies in Genre', Snow Lion; USA, 1996;

PABONGKA, R. Liberation in our Hands, part three. N. Jersey, USA, M.S.T. Press, 2001.

PABONGKA, R. Liberation in our Hands, part two , N. Jersey, USA, M.S.T. Press, 1994;

PERDUE, D. E., Debate in Tibetan Buddhism, Snow Lion Publications, New York, U.S.A., 1992;

RABTEN, G., Mind and its Functions, traduzido por Stephen Batchelor, Vevey, Switzerland, Edition Rabten Choeling, 1992;

SOPA, G.L., HOPKINS, J., Cutting Through Appearances, Snow Lion, N.Y., USA, 1989;

SOPA, G.L, Steps on the Path to Enlightenment - a Commentary on Tsongkhapa's Lamrim Chenmo, Vol. 1: The Foundation Practices. Sommerville, USA, Wisdom Publications, 2004.

SOPA, G.L, Steps on the Path to Enlightenment - a Commentary on Tsongkhapa's Lamrim Chenmo, Vol. 5: 'Insight', Sommerville, USA, Wisdom Publications, 2017. 


\section{ONLINE REFERENCES}

Gold, Jonathan C., "Vasubandhu", The Stanford Encyclopedia of Philosophy (Summer 2015 Edition). Edward N. Zalta (ed.), URL $<$ http://plato.stanford.edu/archives/sum2015/entries/vasubandhu/ $>$.

Gold, Jonathan C., "Vasubandhu", The Stanford Encyclopedia of Philosophy (Summer 2015 Edition), Edward N. Zalta (ed.), URL = $<$ http://plato.stanford.edu/archives/sum2015/entries/vasubandhu/>.

Hayes, Richard, "Madhyamaka", The Stanford Encyclopedia of Philosophy (Spring 2015 Edition), Edward N. Zalta (ed.), URL $=<\underline{\text { http://plato.stanford.edu/archives/spr2015/entries/madhyamaka/ }}$ $>$.

Ronkin, Noa, "Abhidharma", The Stanford Encyclopedia of Philosophy (Fall 2014 Edition), Edward N. Zalta (ed.), URL $=<$ http://plato.stanford.edu/archives/fall2014/entries/abhidharma/ $>$.

Siderits, Mark, "Buddha", The Stanford Encyclopedia of Philosophy (Spring 2015 Edition), Edward N. Zalta (ed.), URL $=<$ http://plato.stanford.edu/archives/spr2015/entries/buddha/ $>$.

Sparham, Gareth, "Tsongkhapa", The Stanford Encyclopedia of Philosophy (Summer 2016 Edition), Edward N. Zalta (ed.), URL = $<$ http://plato.stanford.edu/archives/sum2016/entries/tsongkhapa/ $>$.

Tillemans, Tom, "Dharmakīrti", The Stanford Encyclopedia of Philosophy (Winter 2016 Edition), Edward N. Zalta (ed.), forthcoming URL = <http://plato.stanford.edu/archives/win2016/entries/dharmakiirti/>.

Hershock, Peter, "Chan Buddhism", The Stanford Encyclopedia of Philosophy (Spring 2017 Edition), Edward N. Zalta (ed.), URL = <https://plato.stanford.edu/archives/spr2017/entries/buddhismchan/>. 
Duckworth, Douglas, "Gelukpa [dge lugs pa]", The Stanford Encyclopedia of Philosophy (Spring 2018 Edition), Edward N. Zalta (ed.), URL = <https://plato.stanford.edu/archives/spr2018/entries/gelukpa/>.

<https://www.accesstoinsight.org/tipitaka/sn/sn35/sn35.085.than.html>. 